\title{
Lithostratigraphy of the Palaeogene - Lower Neogene succession of the Danish North Sea
}

Poul Schiøler, Jan Andsbjerg, Ole R. Clausen, Gregers Dam, Karen Dybkjær, Lars Hamberg, Claus Heilmann-Clausen, Erik P. Johannessen, Lars E. Kristensen, lain Prince and Jan A. Rasmussen 


\section{Geological Survey of Denmark and Greenland Bulletin 12}

\section{Keywords}

Lithostratigraphy, biostratigraphy, North Sea Basin, Palaeogene, Neogene.

\section{Cover}

Complex fabric created by multiple small-scale sand intrusions (light) into dark mudstones - such enigmatic fabrics are commonly associated with the sand-rich units of the Rogaland Group in the Siri Canyon area, offshore Denmark. The illustrated section of core is about $10 \mathrm{~cm}$ across and is from the lower Tyr Member (Lista Formation) in the Cecilie-1B well (2346.8 m). Photograph: Jakob Lautrup.

Chief editor of this series: Adam A. Garde

Editorial board of this series: John A. Korstgård, Geological Institute, University of Aarhus; Minik Rosing, Geological Museum, University of Copenhagen; Finn Surlyk, Department of Geography and Geology, University of Copenhagen

Scientific editors of this volume: Jon R. Ineson and Martin Sønderholm

Editorial secretaries: Jane Holst and Esben W. Glendal

Referees: Paul van Veen (Norway) and Robert O’B. Knox (UK)

Illustrations: Stefan Sølberg

Digital photographic work: Benny M. Schark

Graphic production: Knud Gr@phic Consult, Odense, Denmark

Printers: Schultz Grafisk, Albertslund, Denmark

Manuscript received: 29 August 2005

Final version approved: 8 September 2006

Printed: 29 June 2007

ISSN 1604-8156

ISBN 978-87-7871-196-0

\section{Geological Survey of Denmark and Greenland Bulletin}

The series Geological Survey of Denmark and Greenland Bulletin replaces Geology of Denmark Survey Bulletin and Geology of Greenland Survey Bulletin.

\section{Citation of the name of this series}

It is recommended that the name of this series is cited in full, viz. Geological Survey of Denmark and Greenland Bulletin.

If abbreviation of this volume is necessary, the following form is suggested: Geol. Surv. Den. Green. Bull. 12, 77 pp.

\section{Available from}

Geological Survey of Denmark and Greenland (GEUS)

Øster Voldgade 10, DK-1350 Copenhagen K, Denmark

Phone: +45381420 00, fax: +45381420 50, e-mail: geus@geus.dk

and

Geografforlaget A/S

Filosofgangen 24, 1., DK-5000 Odense C, Denmark

Phone: +45634416 83, fax: +45634416 97, e-mail: go@geografforlaget.dk

or at www.geus.dk/publications/bull

(C) De Nationale Geologiske Undersøgelser for Danmark og Grønland (GEUS), 2007

For the full text of the GEUS copyright clause, please refer to www.geus.dk/publications/bull 


\section{Contents}

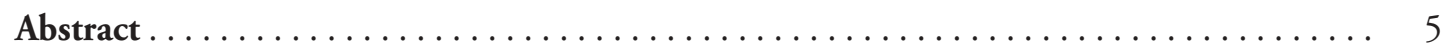

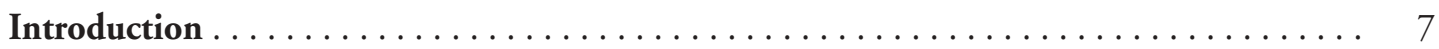

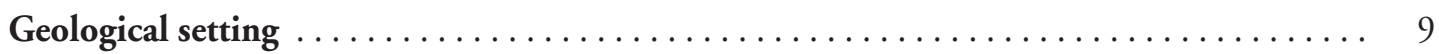

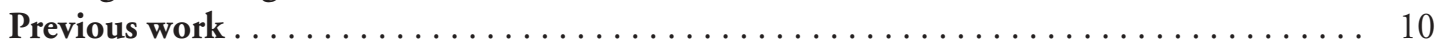

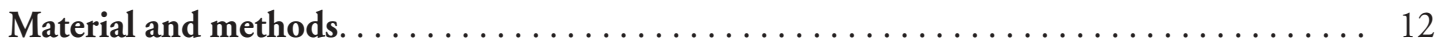

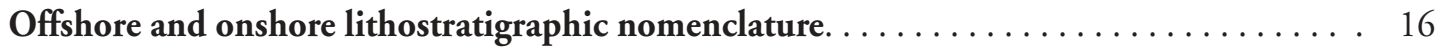

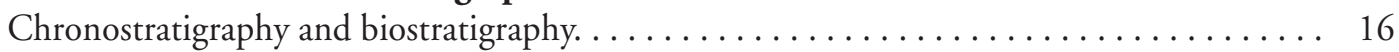

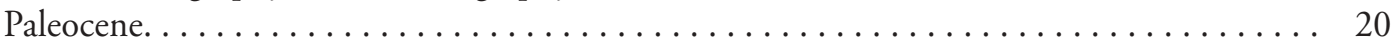

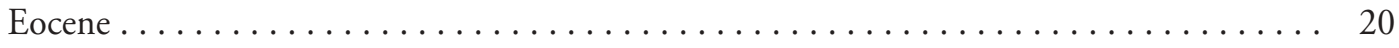

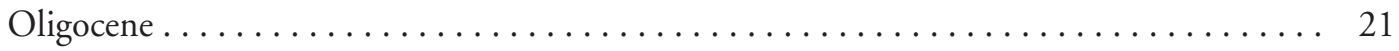

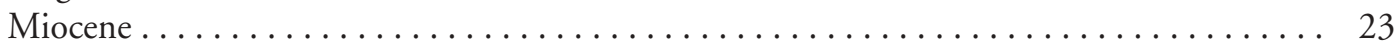

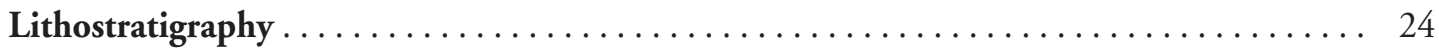

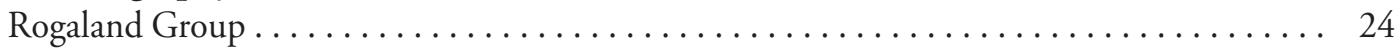

Våle Formation .............................................. 25

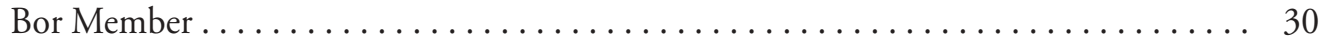

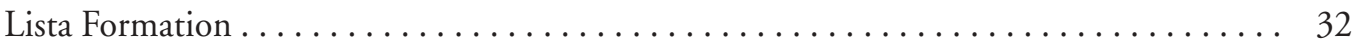

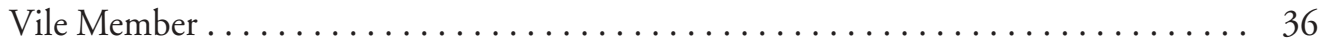

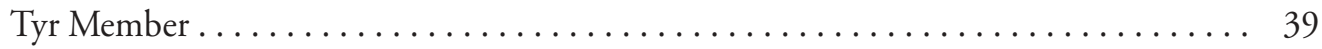

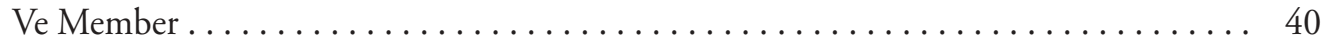

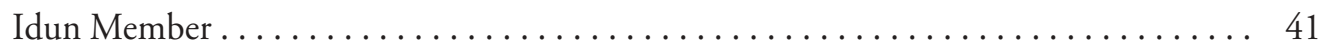

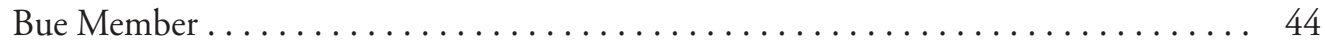

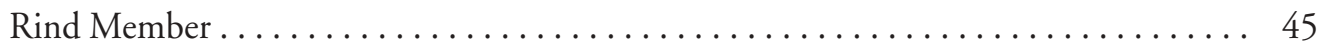

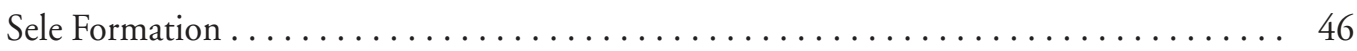

Kolga Member ..................................... 50

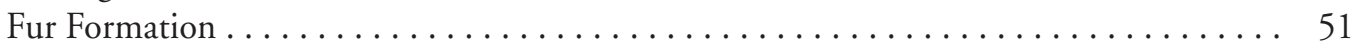

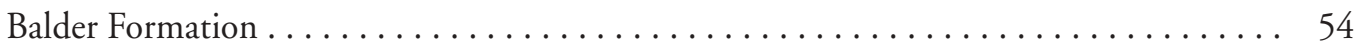

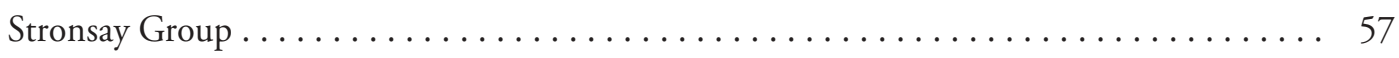

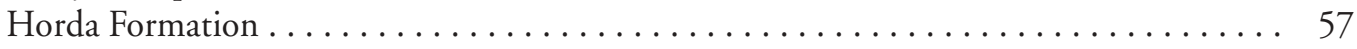

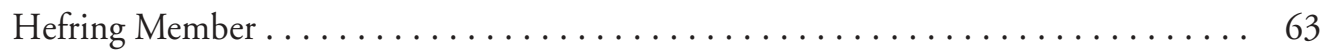

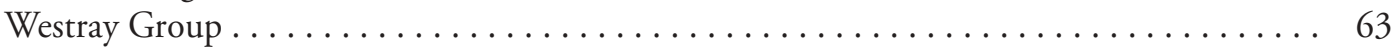

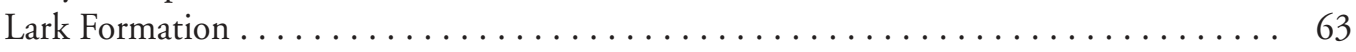

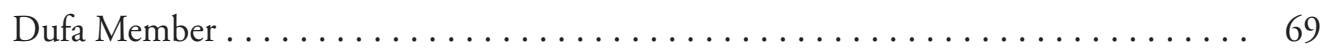

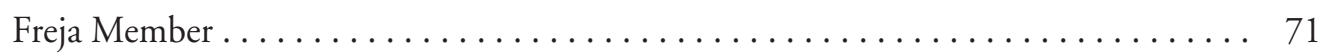

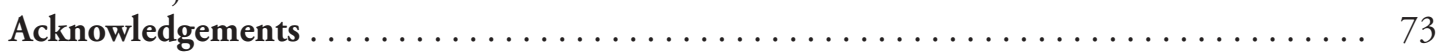

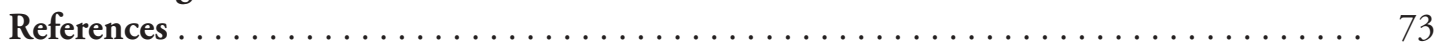





\section{Abstract}

Schiøler, P., Andsbjerg, J., Clausen, O.R., Dam, G., Dybkjær, K., Hamberg, L., Heilmann-Clausen, C., Johannessen, E.P., Kristensen, L.E., Prince, I. \& Rasmussen, J.A. 2007: Lithostratigraphy of the Palaeogene - Lower Neogene succession of the Danish North Sea. Geological Survey of Denmark and Greenland Bulletin 12, 77 pp. + 5 plates.

As a result of a lithological, sedimentological and biostratigraphic study of well sections from the Danish sector of the North Sea, including some recently drilled exploration wells on the RingkøbingFyn High, the lithostratigraphic framework for the siliciclastic Palaeogene to Lower Neogene sediments of the Danish sector of the North Sea is revised. The sediment package from the top of the Chalk Group to the base of the Nordland Group is subdivided into seven formations containing eleven new members. The existing Våle, Lista, Sele, Fur, Balder, Horda and Lark Formations of previously published lithostratigraphic schemes are adequate for a subdivision of the Danish sector at formation level. Bor is a new sandstone member of the Våle Formation. The Lista Formation is subdivided into three new mudstone members: Vile, Ve and Bue, and three new sandstone members: Tyr, Idun and Rind. Kolga is a new sandstone member of the Sele Formation. Hefring is a new sandstone member of the Horda Formation. Freja and Dufa are two new sandstone members of the Lark Formation. Danish reference sections are established for the formations, and the descriptions of their lithology, biostratigraphy, age and palaeoenvironmental setting are updated.

\footnotetext{
Authors' addresses

P.S., J.A., K.D. \& L.E.K., Geological Survey of Denmark and Greenland, Øster Voldgade 10, DK-1350 Copenhagen K, Denmark. "Present address: GNS Science, 1 Fairway Drive, Avalon, P.O. Box 30368, Lower Hutt, New Zealand. E-mail: p.schioler@gns.cri.nz

O.R.C. \& C.H.-C., Department of Earth Sciences, University of Aarhus, Høegh-Guldbergsgade 2, DK-8000 Arhus C, Denmark.

G.D. \& L.H., DONG Energy, Agern Allé 24-26, DK-2970 Hørsholm, Denmark.

I.P. \& E.P.J., Statoil Norway, Forusbeen 50, N-4035 Stavanger, Norway.

J.A.R., Geological Museum, University of Copenhagen, Øster Voldgade 5-7, DK-1350 Copenhagen K, Denmark.
} 

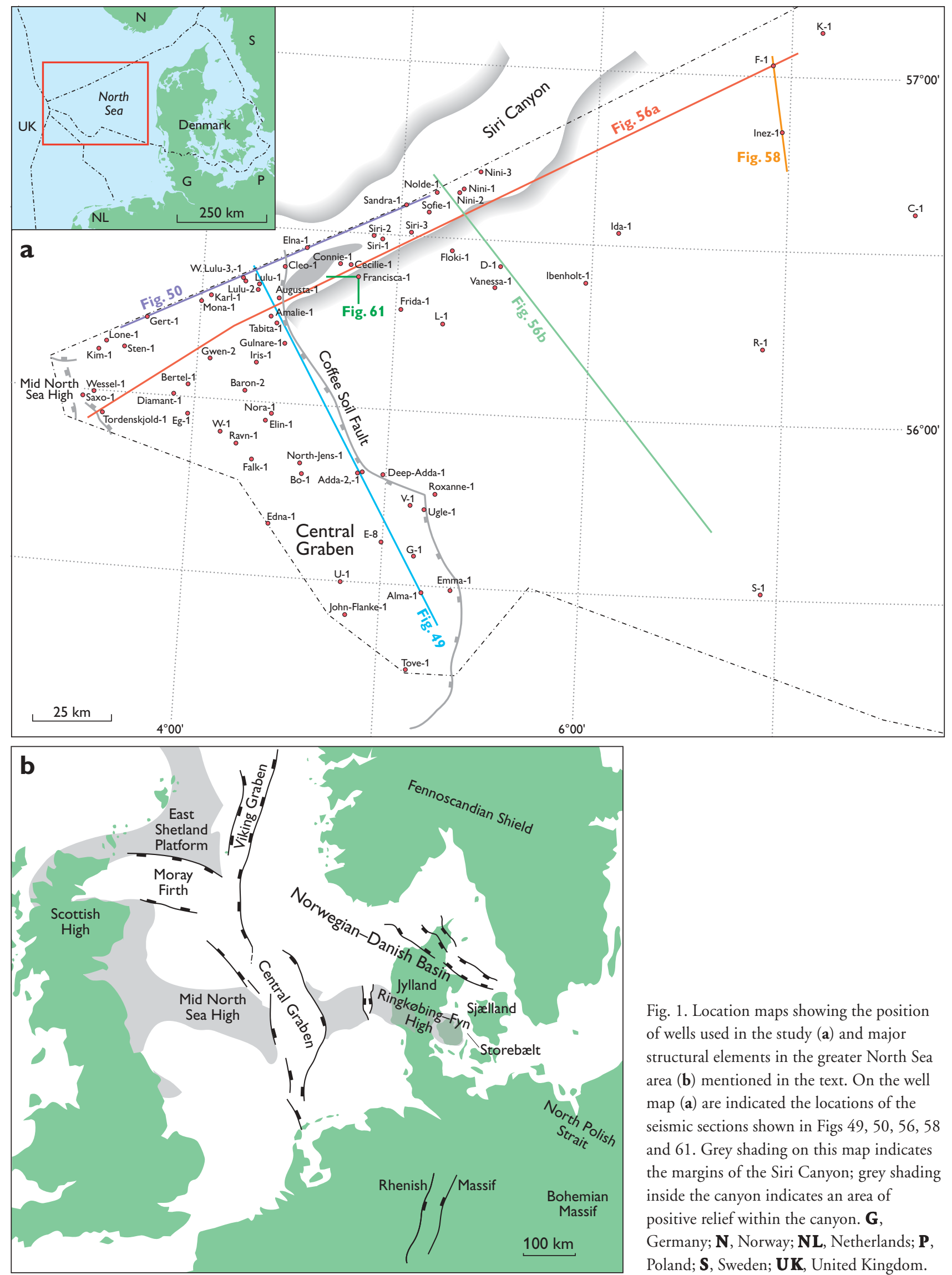

Fig. 1. Location maps showing the position of wells used in the study (a) and major structural elements in the greater North Sea area (b) mentioned in the text. On the well map (a) are indicated the locations of the seismic sections shown in Figs 49, 50, 56, 58 and 61. Grey shading on this map indicates the margins of the Siri Canyon; grey shading inside the canyon indicates an area of positive relief within the canyon. $\mathbf{G}$,

Germany; N, Norway; NL, Netherlands; $\mathbf{P}$, Poland; S, Sweden; UK, United Kingdom. 


\section{Introduction}

Intense drilling activity following the discovery of the Siri Field in 1995 has resulted in an improved understanding of the siliciclastic Palaeogene sediment package in the Danish sector of the North Sea (Fig. 1). Many of the new wells were drilled in the search for oil reservoirs in sandstone bodies of Paleocene-Eocene age. The existing lithostratigraphy was established on the basis of data from a generation of wells that were drilled with deeper stratigraphic targets, with little or no interest in the overlying Palaeogene sedimentary succession. This means that this early scheme does not include Palaeogene sandstone units in the Danish sector. In order to improve the understanding of the distribution, morphology and age of the Palaeogene sediments, in particular the economically important sandstone bodies, a detailed study of this succession in the Danish sector has been carried out. The main aim was to update the lithostratigraphic framework of the succession on the basis of new data from recently drilled wells.

All of the widespread Palaeogene mudstone units in the North Sea were established with Norwegian or United Kingdom (UK) type wells. In the present work, these units have been maintained unchanged or with only slight modifications. Danish reference wells have been established for the units, however, and lithological descriptions have been expanded to cover the characteristics of these units in the Danish sector.

Many of the sandstone bodies recently discovered in the Danish sector have a limited spatial distribution and are derived from sources different from those of most of the contemporaneous sandstone bodies in the Norwegian and UK sectors; furthermore, the Danish sandstone bodies probably neither overlap nor are in contact with the Norwegian/UK sandstones. These units have therefore been established as new in the Danish sector, and have been assigned Danish type and reference sections.
The lithostratigraphy presented herein (Fig. 2) has its base at the top of the Early Paleocene (Danian) Ekofisk Formation (Chalk Group). The top of the study section is at the unconformity between the Late Eocene-Mid-Miocene Westray Group and the Mid-Miocene to Recent Nordland Group.

Oil companies operating in the North Sea have collected a substantial amount of lithostratigraphic data on the Palaeogene successions and a detailed lithostratigraphy has been developed for the Danish and Norwegian sectors (see e.g. Hamberg et al. 2005). A number of informal lithostratigraphic units have been introduced that have subsequently found their way into academia and geological survey organisations. It has been the aim of the present work formally to define these new units. This has been done maintaining their original (albeit informal) names whenever feasible.

It has not been the aim of this work to provide a sequence stratigraphic model for the Palaeogene sediments in the central and eastern North Sea; for this the reader is referred to Michelsen et al. (1992, 1995, 1998), Mudge \& Bujak (1994, 1996a, b), Neal et al. (1994) and Danielsen et al. (1997). The present contribution does not attempt to review the petroleum-related aspects of the Palaeogene succession. Information about this may be found elsewhere, for example in the annual reports from the Danish Energy Authority.

Preliminary results from the present work, including a revised lithostratigraphic scheme, were previously published in a brief review paper (Schiøler et al. 2005). The present contribution formally describes the new stratigraphic units suggested in the review paper and further documents the Palaeogene - Lower Neogene lithostratigraphy in the Danish sector of the North Sea. 

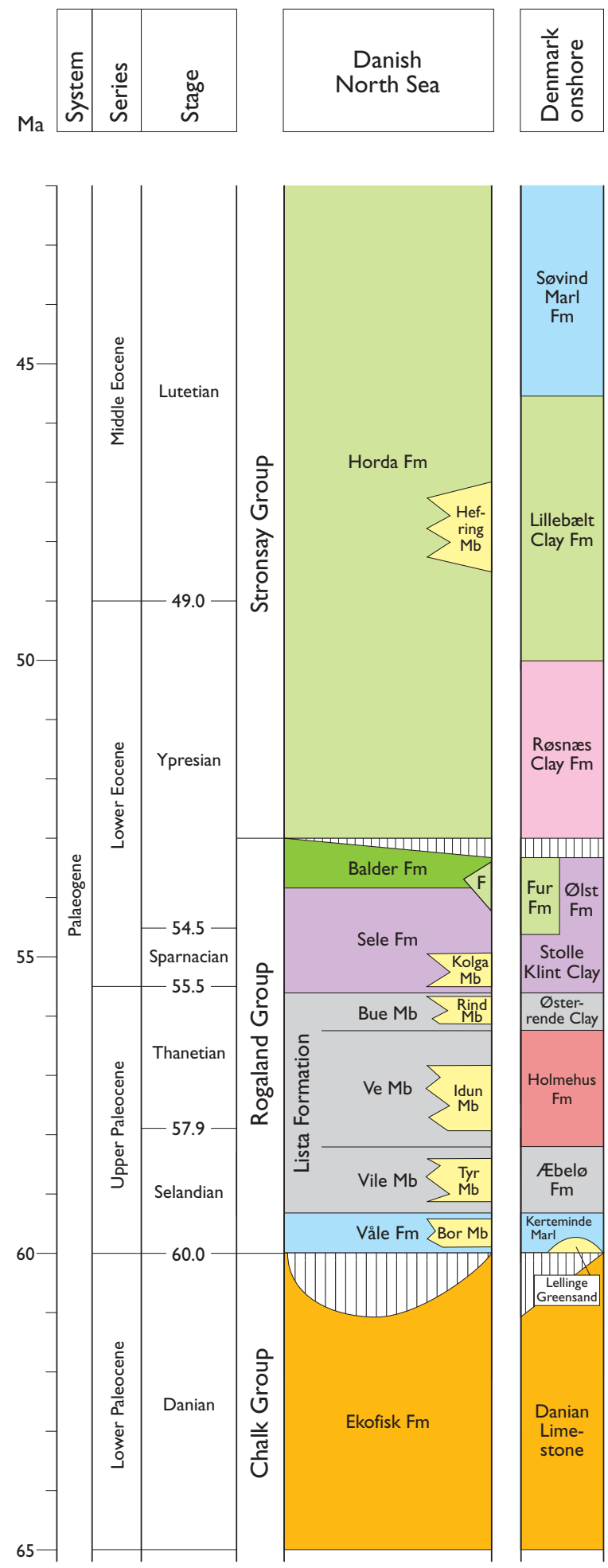

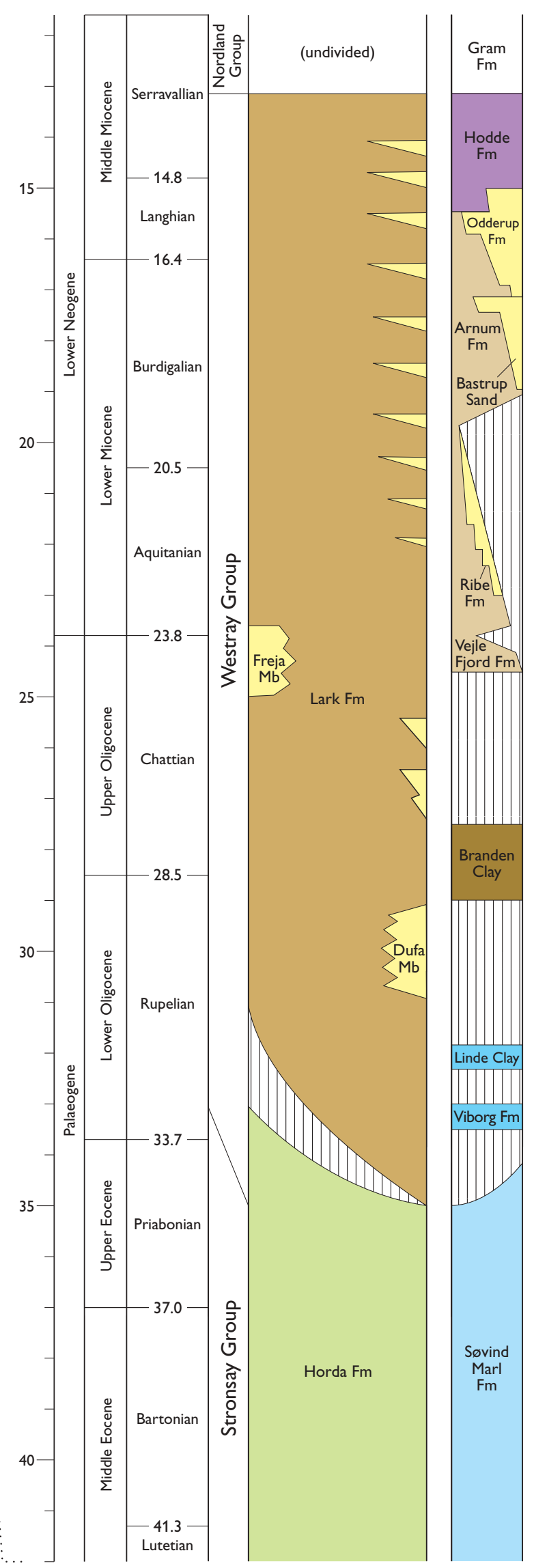




\section{Geological setting}

The Danish sector of the North Sea is situated in the central and eastern North Sea and comprises three major structural elements: the Central Graben, the Norwegian-Danish Basin (the eastern part of the northern North Sea Basin of Rhys 1974) and the Ringkøbing-Fyn High (Fig. 1; the geographic terminology and names of structural elements in the North Sea used herein are adapted from Rhys 1974, Rønnevik et al. 1975, Deegan \& Scull 1977 and Fyfe et al. 2003). The western boundary of the Danish sector largely coincides with the eastern boundary of the Mid North Sea High, the southern boundary largely coincides with the southern limit of the Ringkøbing-Fyn High, and the northern boundary is in the NorwegianDanish Basin. This basin as well as the Ringkøbing-Fyn High are Early Permian structures. Active rifting occurred in the Central Graben from the Middle to Late Jurassic along pre-established Palaeozoic fault trends. Major tectonic activity around the Palaeozoic and Jurassic structures had largely ceased by Late Cretaceous time, and the sediment basin below the central North Sea was largely characterised by regional subsidence (Ziegler 1981). During the Late Cretaceous to Danian sea-level high, pelagic chalk sediments draped the structural highs and the northern and southern North Sea Basins became one North Sea Basin delimited by the Fennoscandian Shield to the north-east, the Rheinish-Bohemian Massif to the south and the British massifs, highs and platforms to the west (see Ziegler 1981 fig. 16 for details). Chalk sedimentation continued through to the end of the Danian Stage when it gave way to hemipelagic and siliciclastic sedimentation. This was probably caused by uplift of the basin margins to the west and east (Ahmadi et al. 2003). However, most of the siliciclastic sediments were derived from

\section{Facing page:}

Fig. 2. Lithostratigraphic column for the Palaeogene and Lower Neogene of the Danish North Sea sector showing the approximate correlation with Danish onshore stratigraphic units. Timescale from Hardenbol et al. (1998), except for the age of the Paleocene-Eocene boundary, which is adapted from Berggren \& Aubry (1996) and the age of the Sparnacian-Ypresian boundary, which is from Aubry et al. (2003). Stratigraphy and ages of pre-Chatian onshore lithostratigraphic units are based on Heilmann-Clausen (1995) and Clemmensen \& Thomsen (2005). Post-Rupelian onshore stratigraphy and ages are from Dybkjær \& Rasmussen (2000) and Rasmussen (2004a). F, Fur Formation. the Scottish High and the East Shetland Platform, uplifted by the Iceland plume (Ahmadi et al. 2003). By the time of peak uplift, in the mid-Thanetian, large sand systems were building out towards the central North Sea. Most sediment came from the west, but the Siri Canyon system, a depression in the top chalk surface, was fed from the Fennoscandian Shield in the north-east and north (Fig 1; Ahmadi et al. 2003; Hamberg et al. 2005).

Thermal subsidence centered above the Central Graben continued through the Eocene as sea level fell and the temperature decreased. Shallow-marine sediments characterised the margins of the North Sea Basin, especially its western margin, whereas basinal mudstone continued to accumulate in the basin centre and in the eastern part of the basin (Joy 1996). Inversions controlled by compression between the Atlantic spreading zone to the northwest and the orogenesis of the Alps to the south added to further uplift of the basin margins and submarine fans and turbidites were deposited near the centre of the basin (Jones et al. 2003).

During the Oligocene, the North Sea Basin became part of a larger NW European basin. Connection with the North Atlantic broadened and enhanced communication with the oceanic water mass to the north-west, whereas the connection to the south through the North Polish Strait became closed for the deep water (Fyfe et al. 2003). Glacio-eustatic sea-level changes became more frequent and controlled the sedimentary cycles. The eastward progradation direction of the Paleocene and Eocene sediments gave way to sediment supply from the European massifs to the far south (Fyfe et al. 2003). Continued subsidence above the Mesozoic rift structures created accommodation space for thick sediment packages of basinal mudstones, and few sandstone units reached the basin depocentre above the Mesozoic rifts (Fyfe et al. 2003). In the Neogene Epoch, sediment started to be derived from the Fennoscandian Shield to the north, and the progradation direction changed to the south-west and west in the Danish sector of the North Sea. 


\section{Previous work}

The Permian to Recent lithostratigraphy of the North Sea was described in two pioneering stratigraphic works. Rhys (1974) provided an overview of the structural elements of the North Sea and gave a brief description of the Palaeogene sediments. Deegan \& Scull (1977) compiled a detailed lithostratigraphic subdivision and lithological description for the central and northern North Sea (Figs 3, 4). They subdivided the siliciclastic Palaeogene, Neogene and Quaternary sediments into five major groups: the Montrose, Moray, Rogaland, Hordaland and Nordland Groups. The Montrose and Moray Groups established for the Outer Moray Firth - Forties area are proximal equivalents to the Rogaland Group and are not present in the Danish sector, whereas the Rogaland, Hordaland and Nordland Groups have widespread distribution in the Danish sector. The succession of major mudstone formations contained within the three basinwide groups has

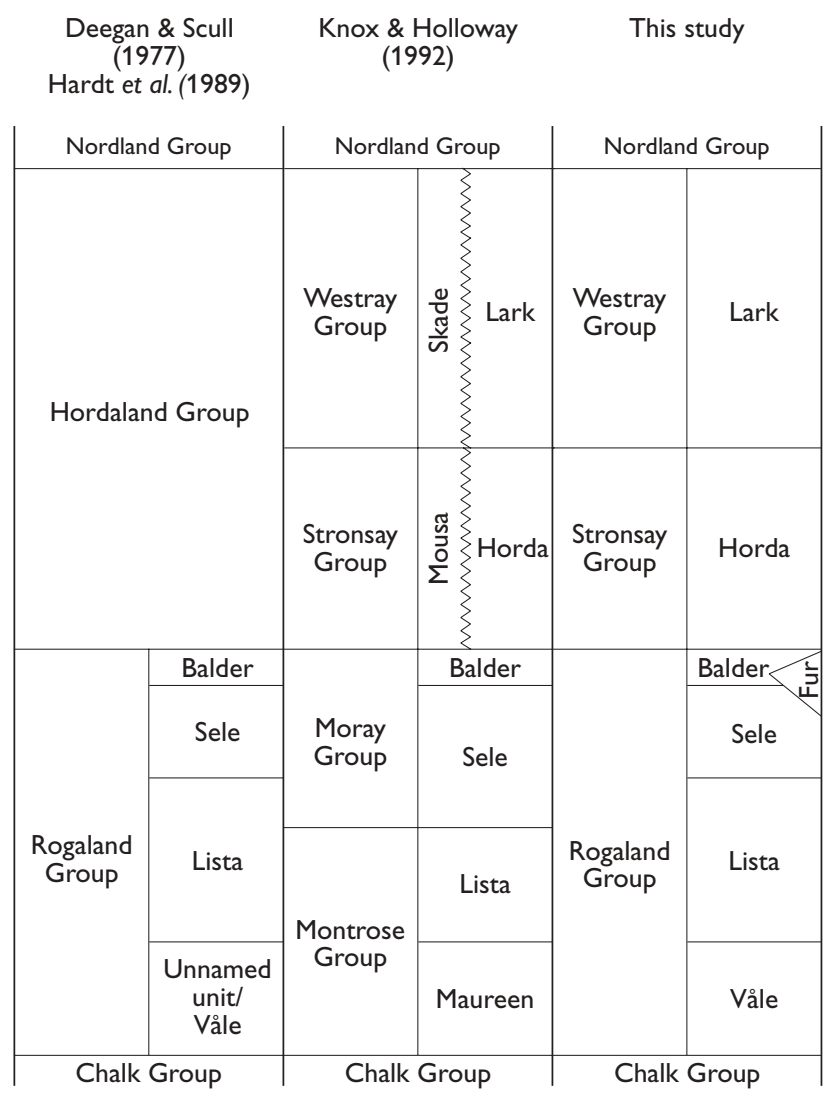

Fig. 3. Correlation chart showing the approximate correlation between key lithostratigraphic schemes for the central and eastern North Sea at group and formation levels. formed the backbone of all subsequent lithostratigraphic schemes for the central and northern North Sea, including that of the present contribution.

The post-Danian Cainozoic succession of the Danish Central Graben was divided into seven informal units by Kristoffersen \& Bang (1982). The Palaeogene comprised five units: North Sea Marl and CEN-1-4 (Fig. 4). The ranks of the units were not stated. Although descriptions and interpretation of the CEN units were detailed, they are essentially informal and have been little used.

A revised lithostratigraphy for the Palaeogene and Neogene of the Norwegian North Sea sector was published by Hardt et al. (1989). Their lithostratigraphic scheme includes a number of new Palaeogene and Neogene sandstone bodies observed in the Norwegian and British sectors of the North Sea (Fig. 4). Some of the names of the new sandstone units established by Hardt et al. (1989) were subsequently used informally for comparable sandstone units discovered in the Danish sector.

Mudge \& Copestake (1992a, b) presented a revised Palaeogene stratigraphy for the Outer Moray Firth and northern North Sea Basins. In their papers they redefined the Moray and Montrose Groups of Deegan \& Scull (1977) and abandoned the Rogaland Group. The authors also demoted the previously established sandstone formations within the two former groups to the rank of members. Besides, in an innovative approach they allowed for a greater influence of biostratigraphic data on the characterisation of the various lithostratigraphic units, an approach which is also followed herein.

Knox \& Holloway (1992) updated the lithostratigraphic scheme for the Palaeogene in the British and Norwegian central and northern North Sea (Figs 3, 4). The authors followed Mudge \& Copestake (1992a, b) in abandoning the Rogaland Group of Deegan \& Scull (1977), and used Mudge \& Copestake's revised definition of the Montrose and Moray Groups for the central North Sea as well. Furthermore, the thick and hitherto undivided Hordaland Group was subdivided into two new groups, the Stronsay Group succeeded by the Westray Group, each containing a distal and a proximal formation. The two distal formations of the two groups, the Horda and Lark Formations, together constitute the bulk of the Palaeogene sediments in the Danish sector of the North Sea and are adopted herein (Figs 2-4). Although sandstone units occur in both the Horda and Lark Formations in the Danish sector, the two proximal sandstone formations of the 
Fig. 4. Correlation chart showing approximate correlation between key lithostratigraphic schemes for the central and eastern North Sea and the Norwegian part of the northern North Sea at formation and member levels. The sequence stratigraphic subdivision of Michelsen et al. (1998) is added for comparison. Sandstone-dominated units indicated in yellow.

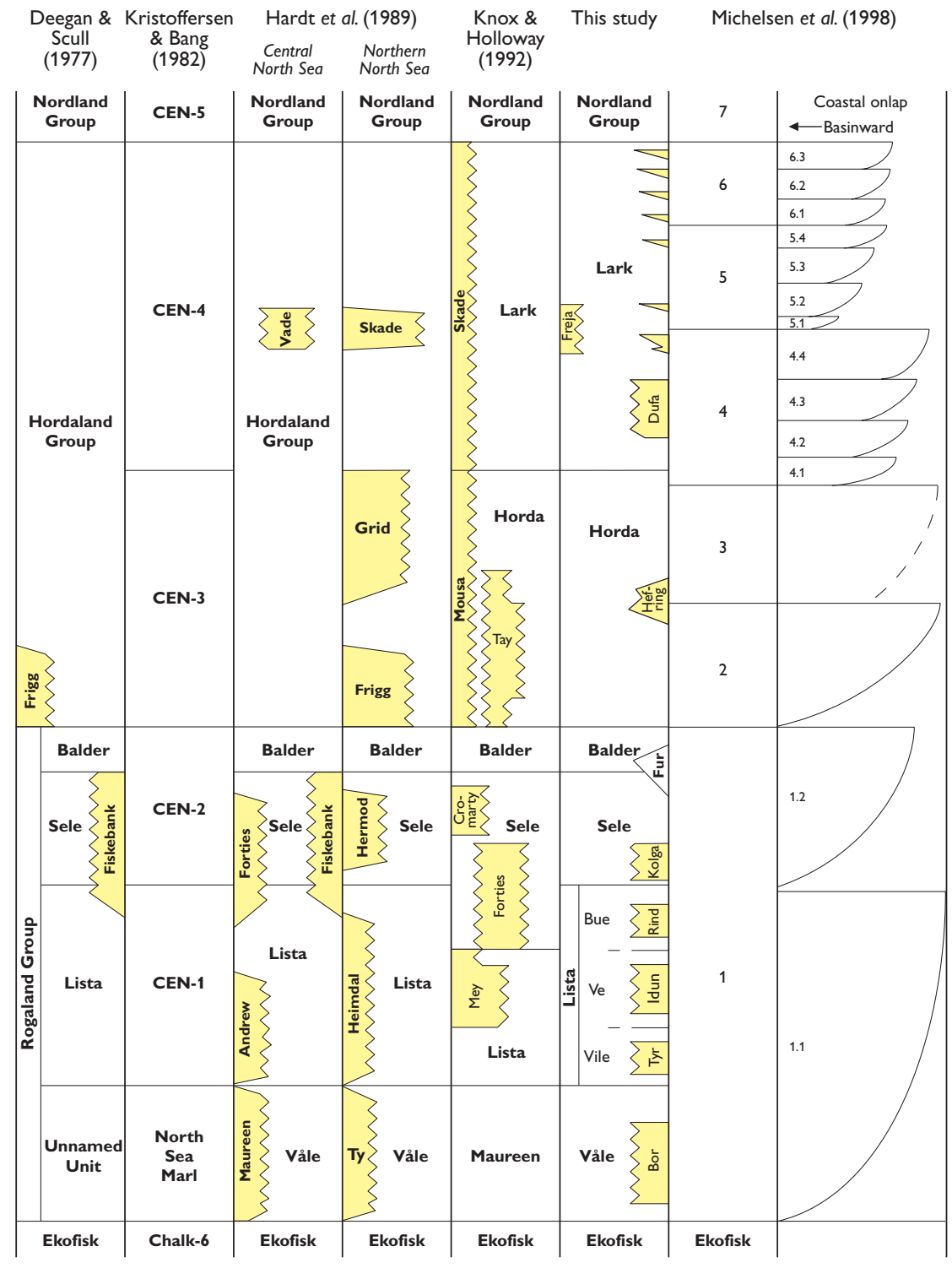

Stronsay and Westray Groups, the Mousa and Skade Formations, are absent from the Danish sector.

Following detailed analysis of new, high-resolution seismic surveys covering the succession in the eastern North Sea area, efforts were focused on establishing a sequence stratigraphic subdivision of the Palaeogene-Neogene sediment package. The sedimentary succession was interpreted in a series of publications from a working group at the University of Aarhus (e.g. Michelsen et al. 1992, 1995, 1998; Michelsen 1993; Danielsen et al. 1997; Huuse \&
Clausen 2001). The result of that work was a subdivision of the Palaeogene to mid-Neogene sediment package covered by the present work into six genetic units (Fig. 4). The sequence stratigraphy of the upper Oligocene to $\mathrm{Mi}$ ocene in the eastern North Sea was dealt with by Rasmussen (2004b). Further sequence stratigraphic contributions covering the larger North Sea Basin including the British and Norwegian sectors are given by Armentrout et al. (1993), Mudge \& Bujak (1994, 1996a, b) and Neal et al. (1994). 


\section{Material and methods}

The present lithostratigraphic subdivision represents the combined results from studies of petrophysical logs, biostratigraphy and seismic profiles, cuttings samples and cored sections. Petrophysical logs from $c .70$ wells in the Danish sector have been scrutinised (see Fig. 1 for well locations). The wells have been correlated using petrophysical logs, predominantly gamma-ray and sonic logs. Five log panels form the basis for the log correlation (Plates 1-5).

Lithostratigraphic well correlation has been supported by biostratigraphic data: biostratigraphic reports from 29 wells have been re-assessed with the aim of identifying key micropalaeontological and palynological events that occur consistently within the study area (taxa used are planktonic and benthic foraminifers, diatoms, radiolaria, sporomorphs and dinoflagellate cysts). Moreover, biostratigraphic sample suites from 11 North Sea wells have been prepared at the Geological Survey of Denmark and Greenland in order to further determine the biostratigraphic event succession. The bulk of material studied for biostratigraphy is based on cuttings samples, and only few

Table 1.Well data for the new type and reference wells in the Danish sector of the North Sea

\begin{tabular}{|c|c|c|c|c|c|c|c|c|c|}
\hline Well & $\begin{array}{l}\text { Type }(t) \text { or reference }(r) \text { well } \\
\text { for listed units: }\end{array}$ & Coordinates & Operator & Spud date & $\begin{array}{l}\text { TD (lo } \\
\text { depth i }\end{array}$ & $\begin{array}{l}\text { gger's } \\
\text { in } m \text { ) }\end{array}$ & $\begin{array}{l}\mathrm{KB} / \mathrm{RT} \text { ele } \\
\text { ( } \mathrm{m} \text { above }\end{array}$ & $\begin{array}{l}\text { evation } \\
\text { e msl) }\end{array}$ & $\begin{array}{l}\text { Water } \\
\text { depth }(m)\end{array}$ \\
\hline Augusta-1 & Bor $M b(t)$, Bue $M b(t), V e M b(t)$ & $\begin{array}{l}56^{\circ} 17^{\prime} 57.40^{\prime \prime} \mathrm{N} \\
04^{\circ} 24^{\prime} 04.64^{\prime \prime} \mathrm{E}\end{array}$ & DONG E\&P a/s & 04.03 .2001 & 2991.0 & MDRT & 37.8 & RT & 65 \\
\hline Cecilie-1 & Bor Mb(r), Tyr Mb(r) & $\begin{array}{l}56^{\circ} 24^{\prime} 23.73^{\prime \prime} \mathrm{N} \\
04^{\circ} 45^{\prime} 42.00^{\prime \prime} \mathrm{E}\end{array}$ & DONG E\&P a/s & 15.10 .2000 & 2361.0 & MDRT & 37.8 & RT & 59.4 \\
\hline Cleo-1 & $\begin{array}{l}\text { Bue } M b(r) \text {, Lista } F m(r) \text {, } \\
\text { Ve } M b(r), V i l e ~ M b(r)\end{array}$ & $\begin{array}{l}56^{\circ} 23^{\prime} 23.54^{\prime \prime} \mathrm{N} \\
04^{\circ} 25^{\prime} 22.70^{\prime \prime} \mathrm{E}\end{array}$ & Chevron Petroleum Co. & 06.02 .1984 & 4866.1 & MDKB & 40.5 & KB & 63.1 \\
\hline Connie-1 & Idun $\mathrm{Mb}(\mathrm{t})$, Rind $\mathrm{Mb}(\mathrm{t})$ & $\begin{array}{l}56^{\circ} 24^{\prime} 28.34^{\prime \prime} \mathrm{N} \\
04^{\circ} 42^{\prime} 30.36^{\prime \prime} \mathrm{E}\end{array}$ & DONG E\&P a/s & 02.02 .2001 & 2351.8 & MDRT & 37.8 & RT & 61.5 \\
\hline $\mathrm{E}-8$ & $\begin{array}{l}\text { Bue } M b(r) \text {, Lista } F m(r), V e M b(r) \text {, } \\
\text { Vile } M b(r) \text {,Våle } F m(r)\end{array}$ & $\begin{array}{l}55^{\circ} 38^{\prime} 13.42^{\prime \prime} \mathrm{N} \\
04^{\circ} 59^{\prime} 11.96^{\prime \prime} \mathrm{E}\end{array}$ & Maersk Oil \& Gas a/s & 08.04.1994 & 2527.4 & MDKB & 36.6 & KB & 43.6 \\
\hline F-1 & Dufa $M b(r)$ & $\begin{array}{l}57^{\circ} 01^{\prime} 53.4^{\prime \prime} \mathrm{N} \\
06^{\circ} 54^{\prime} 28.6^{\prime \prime} \mathrm{E}\end{array}$ & Gulf Oil Company & 06.10 .1968 & 2421.6 & MDKB & 37.19 & KB & 40.8 \\
\hline Floki-1 & Hefring $M b(t)$ & $\begin{array}{l}56^{\circ} 27^{\prime} 48.58^{\prime \prime} \mathrm{N} \\
05^{\circ} 16^{\prime} 47.11^{\prime \prime} \mathrm{E}\end{array}$ & Kerr-McGee Int. aps & 29.08 .2000 & 1878 & MDRT & 35.8 & RT & 53.2 \\
\hline Francisca-1 & Freja $M b(t)$ & $\begin{array}{l}56^{\circ} 22^{\prime} 27.95^{\prime \prime} \mathrm{N} \\
04^{\circ} 48^{\prime} 05.30^{\prime \prime} \mathrm{E}\end{array}$ & Dansk Operatørselskab i/s & 20.07.1998 & 1888.5 & MDRT & 36.4 & KB & 60 \\
\hline Frida-1 & Freja $\mathrm{Mb}(\mathrm{r})$ & $\begin{array}{l}56^{\circ} 17^{\prime} 14.15^{\prime \prime} \mathrm{N} \\
05^{\circ} 01^{\prime} 50.20^{\prime \prime} \mathrm{E}\end{array}$ & Dansk Operatørselskab i/s & 26.07.1997 & 2274 & MDRT & 39.0 & RT & 54.3 \\
\hline Inez-1 & Dufa $M b(t)$, Fur Fm(r) & $\begin{array}{l}56^{\circ} 50^{\prime} 28.39^{\prime \prime} \mathrm{N} \\
06^{\circ} 57^{\prime} 41.62^{\prime \prime} \mathrm{E}\end{array}$ & Chevron Petroleum Co. & 11.09.1977 & 1983.9 & MDKB & 35.1 & KB & 35.4 \\
\hline K-1 & Fur Fm(r) & $\begin{array}{l}57^{\circ} 07^{\prime} 37.74^{\prime \prime} \mathrm{N} \\
07^{\circ} 09^{\prime} 43.11^{\prime \prime} \mathrm{E}\end{array}$ & California Oil Co. & 22.01.1970 & 2292.4 & MDKB & 37.2 & KB & 56.4 \\
\hline Mona-1 & $\begin{array}{l}\text { Balder } \mathrm{Fm}(r) \text {, Horda } \mathrm{Fm}(\mathrm{r}) \text {, } \\
\text { Lark } \mathrm{Fm}(\mathrm{r})\end{array}$ & $\begin{array}{l}56^{\circ} 16^{\prime} 35.94^{\prime \prime} \mathrm{N} \\
04^{\circ} 00^{\prime} 15.81^{\prime \prime} \mathrm{E}\end{array}$ & Chevron Petroleum Co. & 03.10 .1982 & 4241.6 & MDKB & 36.6 & KB & 65.5 \\
\hline Nini-3 & Kolga Mb(r), Tyr Mb(t) & $\begin{array}{l}56^{\circ} 41^{\prime} 31.96^{\prime \prime} \mathrm{N} \\
05^{\circ} 24^{\prime} 12.35^{\prime \prime} \mathrm{E}\end{array}$ & DONG E\&P a/s & 12.01 .2001 & 1851.2 & MDRT & 37.3 & RT & 58.2 \\
\hline Sandra-1 & Rind $\mathrm{Mb}(\mathrm{r})$ & $\begin{array}{l}56^{\circ} 35^{\prime} 13.33^{\prime \prime} \mathrm{N} \\
05^{\circ} 01^{\prime} 35.19^{\prime \prime} \mathrm{E}\end{array}$ & Statoil E\&P a/s & 18.06.1998 & 2139 & MDRT & 36 & KB & 65 \\
\hline Siri-1 & $\begin{array}{l}\text { Horda } F m(r) \text {, Lark } F m(r) \text {, } \\
\text { Sele } F m(r) \text {,Våle } F m(r)\end{array}$ & $\begin{array}{l}56^{\circ} 29^{\prime} 11.10^{\prime \prime} \mathrm{N} \\
04^{\circ} 54^{\prime} 57.49^{\prime \prime} \mathrm{E}\end{array}$ & Statoil E\&P a/s & 28.11.1995 & 2220 & MDKB & 23 & KB & 60 \\
\hline Siri-2 & Idun $\mathrm{Mb}(\mathrm{r})$ & $\begin{array}{l}56^{\circ} 29^{\prime} 40.53^{\prime \prime} \mathrm{N} \\
04^{\circ} 52^{\prime} 13.26^{\prime \prime} \mathrm{E}\end{array}$ & Statoil E\&P a/s & 03.08 .1996 & 2297.5 & MDRT & 36.6 & RT & 60.6 \\
\hline Siri-3 & $\begin{array}{l}\text { Balder } \mathrm{Fm}(r), \text { Kolga } \mathrm{Mb}(\mathrm{t}) \text {, } \\
\text { Vile } \mathrm{Mb}(\mathrm{t})\end{array}$ & $\begin{array}{l}56^{\circ} 30^{\prime} 34.92^{\prime \prime} \mathrm{N} \\
05^{\circ} 03^{\prime} 48.27^{\prime \prime} \mathrm{E}\end{array}$ & Statoil E\&P a/s & 30.08 .1996 & 2171.5 & MDRT & 36.6 & RT & 60.1 \\
\hline Tabita-1 & Sele Fm(r) & $\begin{array}{l}56^{\circ} 13^{\prime} 37.50^{\prime \prime} \mathrm{N} \\
04^{\circ} 23^{\prime} 47.56^{\prime \prime} \mathrm{E}\end{array}$ & Statoil E\&P a/s & 10.09 .1983 & 4353 & MDKB & 40 & KB & 65 \\
\hline
\end{tabular}

Fm: Formation. Mb: Member. MDRT: Measured Depth below Rotary Table. MDKB: Measured Depth below Kelly Bushing. 


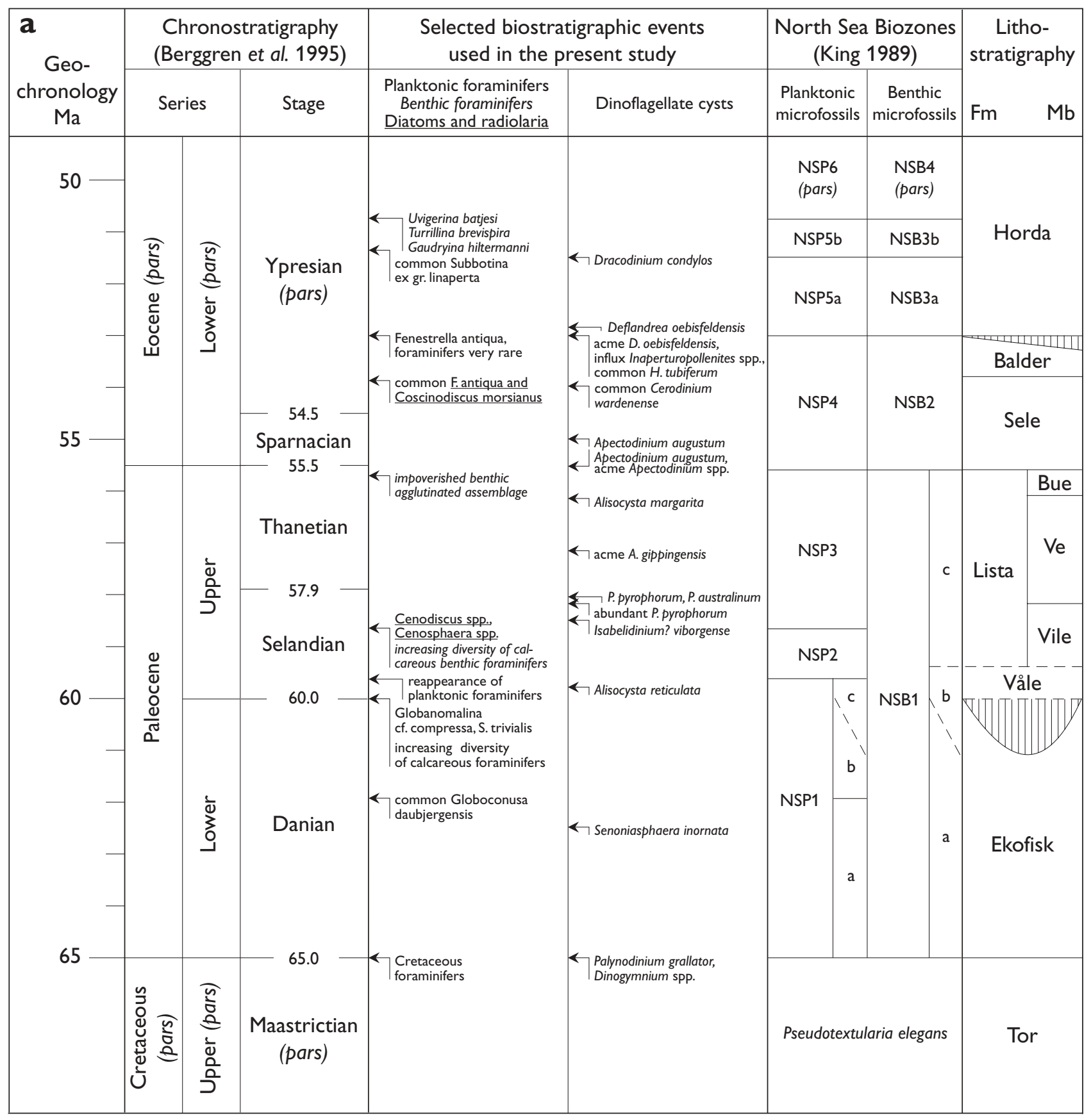

Fig. 5. Chronostratigraphy and biostratigraphy of the Paleocene - Middle Miocene. a: Paleocene-Eocene. b: Eocene-Oligocene. c: Oligocene Middle Miocene. Calibration of chronostratigraphic units follows Hardenbol et al. (1998), Berggren \& Aubry (1996) for the Paleocene-Eocene boundary and Aubry et al. (2003) for the Sparnacian-Ypresian boundary. Key dinoflagellate datums are calibrated mainly using age estimates from Hardenbol et al. (1998) and Williams et al. (2004). Key microfossil datums are calibrated via their correlation with calibrated dinoflagellate datums as suggested by Mudge \& Bujak (1996b), using age estimates from Hardenbol et al. (1998) and Williams et al. (2004). The combined event succession is correlated with the North Sea microfossil zonation of King (1989) and lithostratigraphic units treated herein. In the microfossil event column, the planktonic foraminifer events appear in normal font, benthic foraminifers in italics; diatoms and radiolarians are underlined. 


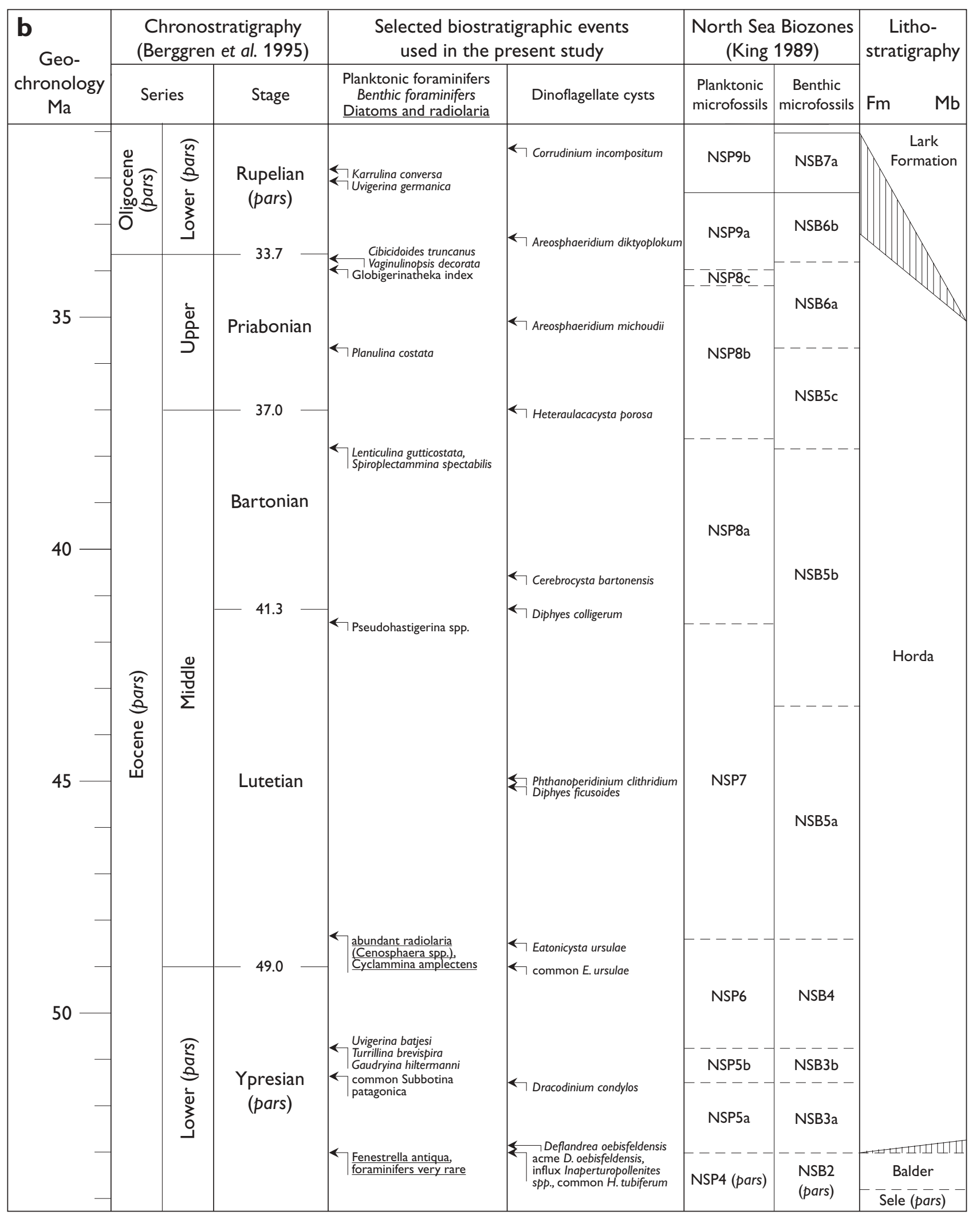

Fig. 5b. Chronostratigraphy and biostratigraphy of the Eocene-Oligocene. 


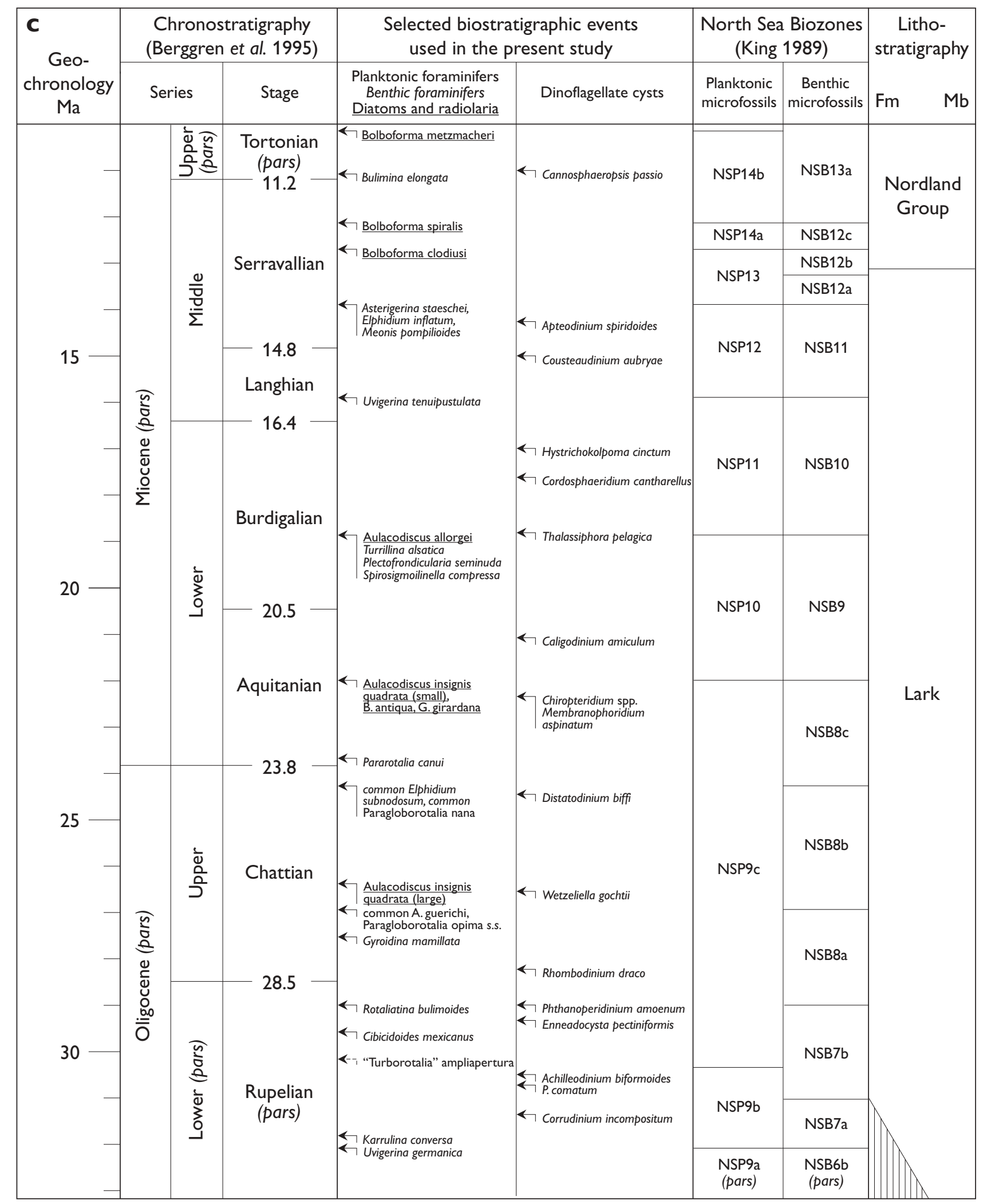

Fig 5c. Chronostratigraphy and biostratigraphy of the Oligocene - Middle Miocene. 
core samples have been available. As the use of stratigraphic lowest occurrences (LO) of taxa in cuttings samples may be hampered due to downhole caving, the event succession comprises almost exclusively stratigraphic highest occurrences $(\mathrm{HO})$ of taxa (a single significant LO is included in the succession). The event succession is shown in Fig. $5 \mathrm{a}-\mathrm{C}$; its correlation with international and North Sea biozones is shown in Fig. 6a-c.

Seismic sections from the 2-D and 3-D seismic surveys CGD85, DK-1, RTD81-RE94, UCG96 and UCGE97 have been used to further support the well correlation and to map the stratigraphic units in areas with only scattered well coverage. The combined results from the correlation and mapping procedures are presented as isochore maps for individual stratigraphic units.

Inspection of cuttings samples from 16 key wells supplemented with sedimentological studies of cored inter- vals from 23 wells have formed the basis for the lithological and sedimentological descriptions of the units.

The well depths mentioned in the lithostratigraphy section are loggers' depths measured either from rotary table (MDRT) or kelly bushing (MDKB). Supplementary data for new type and reference wells are provided in Table 1.

The names assigned to the new lithostratigraphic units defined herein are derived from Nordic mythology and thus follow the nomenclatural tradition previously established for the Norwegian North Sea (Isaksen \& Tonstad 1989).

It should be noted that the micropalaeontology-based palaeoenvironmental terminology used herein was originally developed for a passive margin situation (e.g. the terms 'neritic' and 'bathyal' to indicate the physiographic zones 'shelf' and 'shelf- slope', respectively). Its application herein to the epicontinental North Sea Basin solely relates to depositional depth.

\section{Offshore and onshore lithostratigraphic nomenclature}

There is a high degree of lithological similarity between the Palaeogene-Neogene mudstone succession in Danish offshore boreholes and that in onshore exposures and boreholes. However, the status of the Danish onshore units is quite varied since many units were named before a standard for description of a lithostratigraphic unit was established; some fulfil these requirements, whereas others are still informal. If a previously established onshore unit and an offshore unit can be demonstrated to be identical (e.g. the Holmehus Formation and the new Ve Member proposed herein), the name of the onshore unit theoretically has priority over the name of the offshore unit (Salvador 1994). In other cases, names of offshore units can be argued to have priority over onshore units (e.g. Sele and Balder Formations over Ølst Formation). However, in order to acknowledge the traditional distinction between offshore and onshore stratigraphic nomenclature, the two sets of nomenclature are kept separate herein. Whenever possible, comments are given in the text to explain the relationship between offshore and onshore Danish stratigraphic nomenclature. A correlation between the two sets of nomenclature is shown in Fig. 2.

\section{Chronostratigraphy and biostratigraphy}

Age assessment of the lithostratigraphic units in the North Sea sedimentary succession is based on correlation between key biostratigraphic events encountered in the units and the calibrated standard chronostratigraphy published by Berggren et al. (1995), with modification for the Paleocene-Eocene boundary following ratification of its position by the International Union of Geological Scientists (Aubry et al. 2002). The key events are from biostratigraphic zonation schemes established for the North Sea area. Planktonic and benthic microfossils are covered by the zonation schemes of King (1983, 1989; Figs 5a-c, $6 a-c)$. Dinoflagellates from the Paleocene and Eocene Epochs are covered by the zonation scheme of Mudge \& Bujak (1996b; Fig. 6a, b); the Oligocene and Miocene Epochs are covered by the zonation schemes of Costa \& Manum (1988) with modifications by Köthe (1990, 2003; Fig. 6b, c). Key events from these schemes used in this study are listed in Fig. 5a-c.

For the dinoflagellate events, geochronological calibration has been largely established using age estimates from Hardenbol et al. (1998), Munsterman \& Brinkhuis (2004) and Williams et al. (2004). For events not mentioned in these three publications, the works of Mudge \& Bujak 


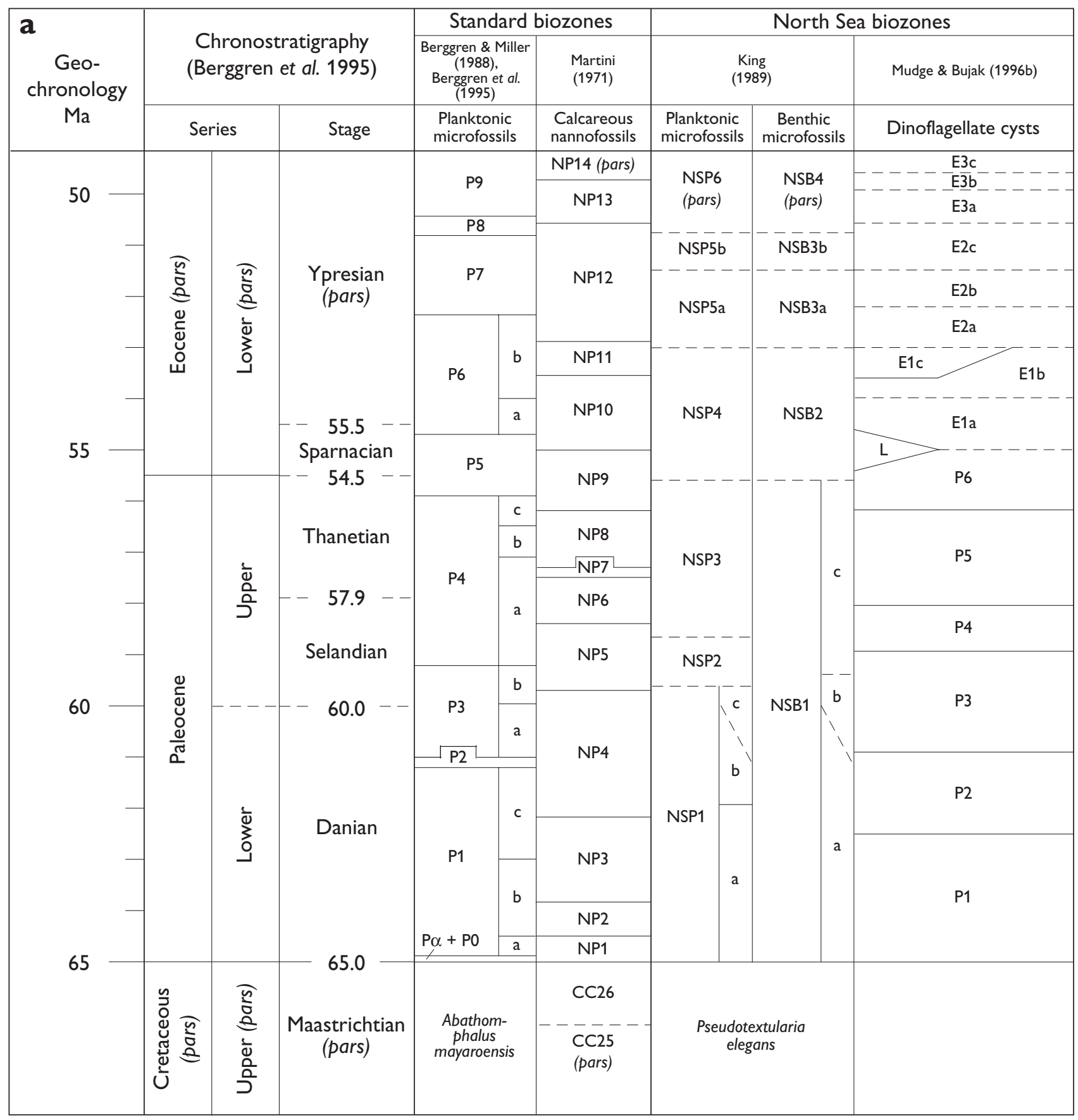

Fig. 6. Biostratigraphic correlation charts showing approximate correlation of calibrated standard planktonic foraminifer and nannofossil biozones with North Sea microfossil and dinoflagellate biozones. Calibration of the standard biozones follows Hardenbol et al. (1998). Relationships between the North Sea biozones are approximate and their correlation with the standard zones may deviate from that of the original authors (for discussion, see text). a: Paleocene-Eocene biostratigraphic correlation chart. b: Eocene-Oligocene biostratigraphic correlation chart. c: Oligocene - Middle Miocene biostratigraphic correlation chart. 


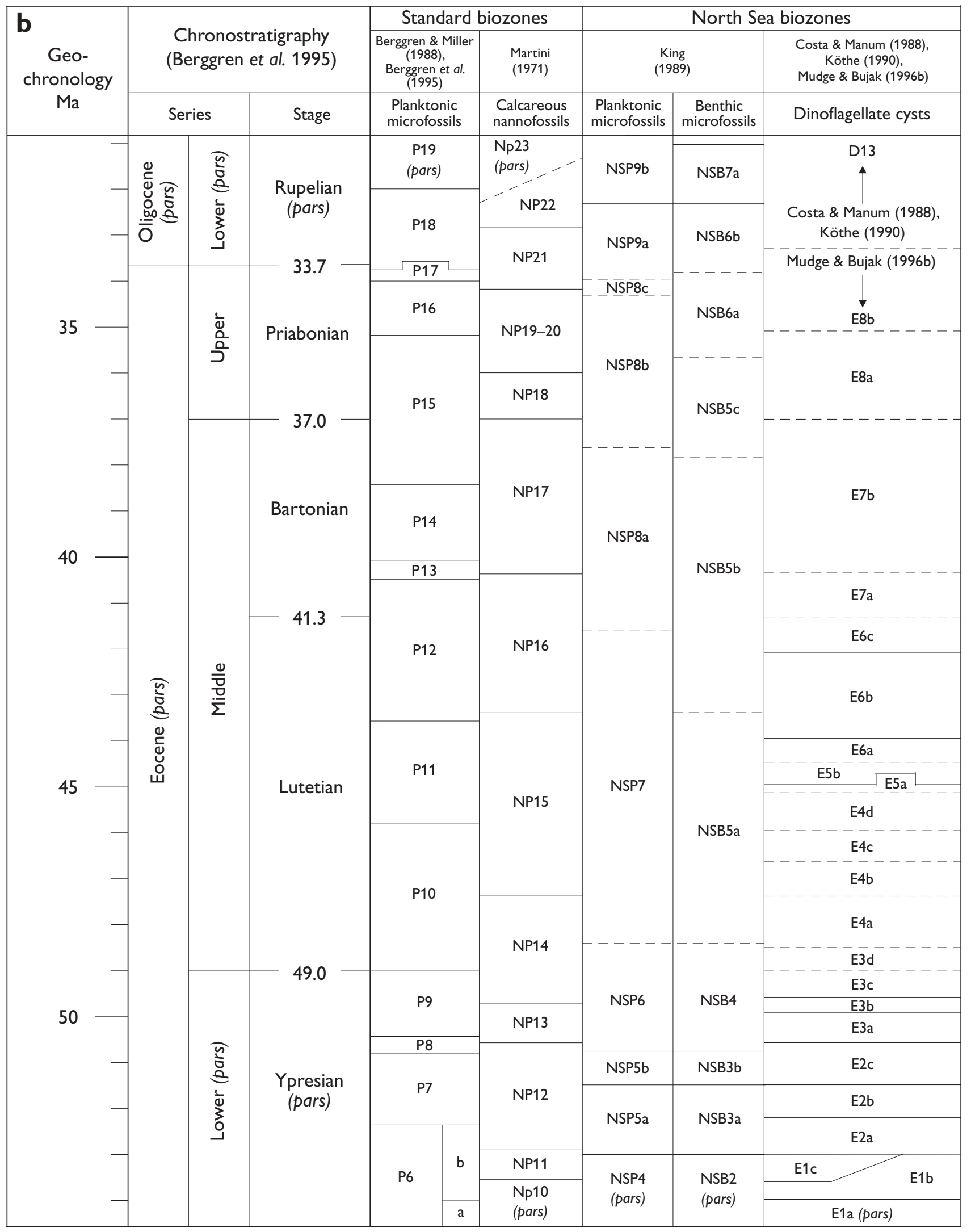

Fig. 6b. Eocene-Oligocene biostratigraphic correlation chart. 


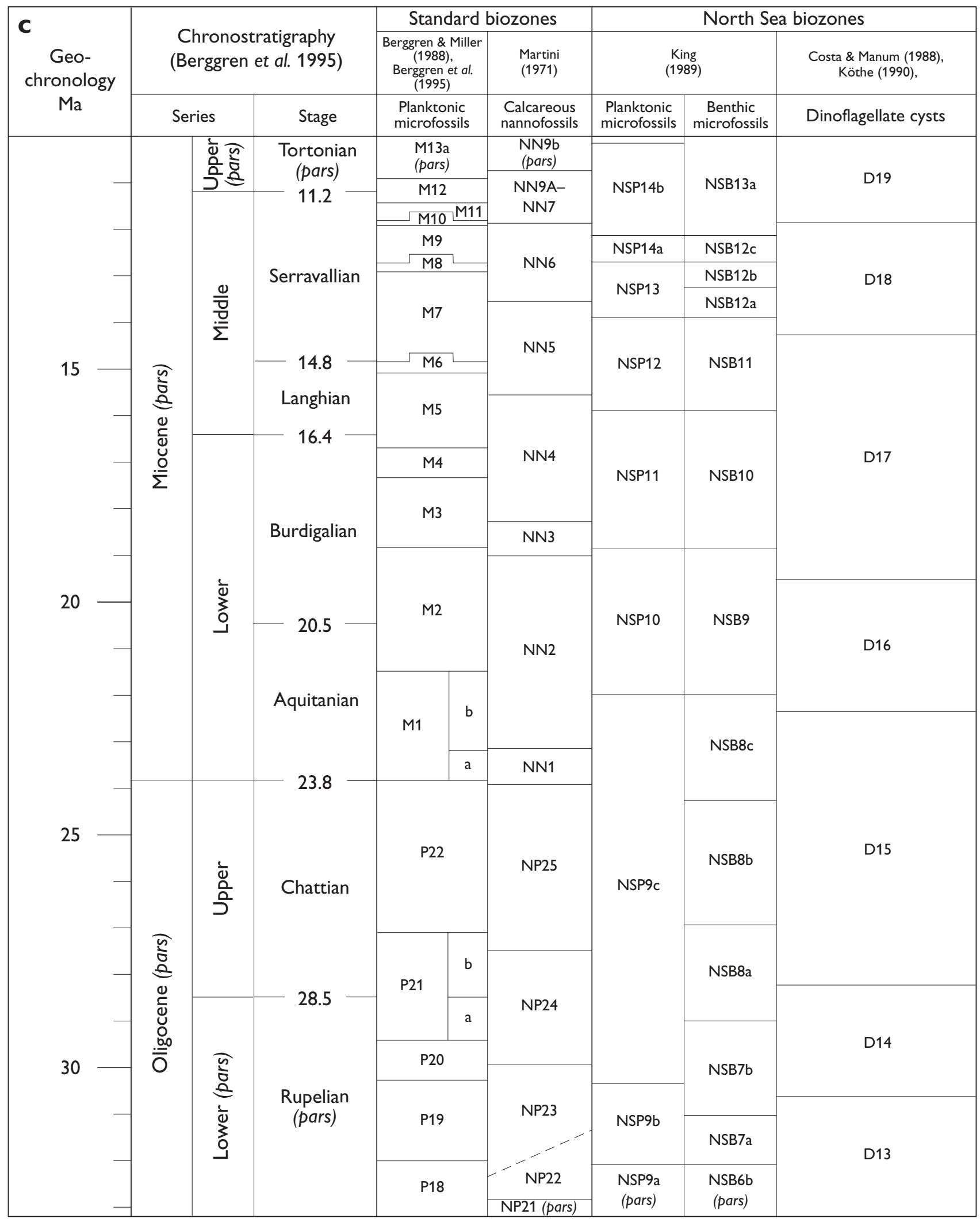

Fig. 6c. Oligocene - Middle Miocene biostratigraphic correlation chart. 
(1996b), Dybkjær (2004), Piasecki (2005) and Schiøler (2005) have been consulted. However, whereas Hardenbol et al. (1998) and Williams et al. (2004) used the timescale of Berggren et al. (1995), Mudge \& Bujak used the slightly older timescale from Haq et al. (1987) for calibration of their events. Therefore, the ages of events only listed by Mudge \& Bujak have been recalibrated herein to conform to the timescale of Berggren et al. (1995).

King (1989) calibrated his planktonic and benthic microfossil zone markers with the standard chronostratigraphic scale of Berggren et al. (1985a, b). However, King noted that only a few first-order correlations were possible; most of the calibrations were made using dinoflagellates, planktonic foraminifers and nannoplankton from onshore sections in the North Sea Basin (King 1989 p. 420); the correlation of the Lower Miocene is particularly uncertain (King 1989 p. 446). Paleocene and Eocene key planktonic and benthic microfossil events from King (1989) were subsequently correlated with the North Sea dinoflagellate events by Mudge \& Bujak (1996b). By using the above-mentioned recalibration of key dinoflagellate events from Mudge \& Bujak (1996b), it is feasible to indirectly correlate King's North Sea microfossil events with the timescale of Berggren et al. (1995). This has been attempted in Fig. 5a-c.

Figure 6a-c shows the relationships between the North Sea biozones and their correlation with the standard planktonic foraminifer and calcareous nannofossil zones. However, it should be noticed that in a few cases the correlation of the North Sea microfossil and dinoflagellate zones with the standard zones in Fig. $6 \mathrm{a}-\mathrm{c}$ is at variance with that of the authors of the same zones. This is an effect of improved age determinations of the standard zones and the dinoflagellate events used to calibrate the North Sea microfossil zones.

The section below outlines the current status for the Palaeogene and Neogene chronostratigraphic units covered by the studied succession and lists key biostratigraphic events used for chronostratigraphic correlation of the succession.

\section{Paleocene}

The bases of the Selandian and Thanetian Stages, which together constitute the Upper Paleocene Series, have yet to be formally defined. However, ongoing work in the International Subcommission on Palaeogene Stratigraphy indicates that the Global Standard Stratotype-section and Point (GSSP) of the base of the Selandian Stage will probably be close to the P2-P3a or the P3a-P3b standard planktonic foraminifer zone boundary, while the GSSP for the Thanetian Stage will probably be at the base of Magnetochron C26n (Gradstein \& Ogg 2002). Hardenbol et al. (1998) followed Berggren et al. (1995) in placing the base of the Selandian Stage at the base of Zone $\mathrm{P} 3 \mathrm{a}$, at the lowest occurrence of the planktonic foraminifer Morozovella angulata. However, many of the microfossil species that characterise the Danian-Selandian boundary interval in the international zonation schemes, including $M$. angulata, are extremely rare or absent in the North Sea Basin thereby hampering chronostratigraphic correlation of the boundary. Based on a study of core material from the type area for the Danian and Selandian Stages, Clemmensen \& Thomsen (2005) concluded that the Danian-Selandian stage boundary is located in the upper part of the NP4 standard nannofossil zone, close to the NP4-NP5 zone boundary, approximately at the P3a$\mathrm{P} 3 \mathrm{~b}$ zone boundary, at $c .60 \mathrm{Ma}$ on the timescale of Hardenbol et al. (1998). They further concluded that there is a hiatus between the Danian and Selandian Stages in the Danish area outside the Central Graben due to truncation of the Danian limestones of the Ekofisk Formation (Fig. 5a; Clemmensen \& Thomsen 2005). Hence, the Danian-Selandian stage boundary is herein placed just below the downhole reappearance (provisional HO) of planktonic foraminifers and the $\mathrm{HO}$ of the dinoflagellate Alisocysta reticulata, but above the closely spaced events marked by the HO of the planktonic foraminifers Subbotina trivialis and Globanomalina cf. compressa (e.g. Jones 1999; Mudge \& Bujak 2001).

The Selandian-Thanetian stage boundary is herein approximated by the $\mathrm{HO}$ of the dinoflagellate Palaeoperidinium pyrophorum, at the base of the $\mathrm{P} 5$ dinoflagellate Zone of Mudge \& Bujak (1996b). This level is close to the base of Magnetochron C26n, according to Hardenbol et al. (1998).

\section{Eocene}

The base of the Eocene is at the base of the negative carbon isotope excursion (CIE) at $55.5 \mathrm{Ma}$ (Berggren \& Aubry 1996; Aubry et al. 2002). This position is below the base of the Ypresian Stage, the lowermost Eocene Stage. Therefore it has been proposed to reintroduce the Sparnacian Stage as the new basal Eocene Stage between the CIE and the base of the Ypresian (Aubry et al. 2003). The CIE has been correlated with the proliferation of the dinoflagellate genus Apectodinium, an event recognised globally (e.g. Knox 1996; Crouch et al. 2001). Onshore Denmark, the CIE and the proliferation of Apectodinium coincides precisely with the laminated Stolle Klint Clay in the 


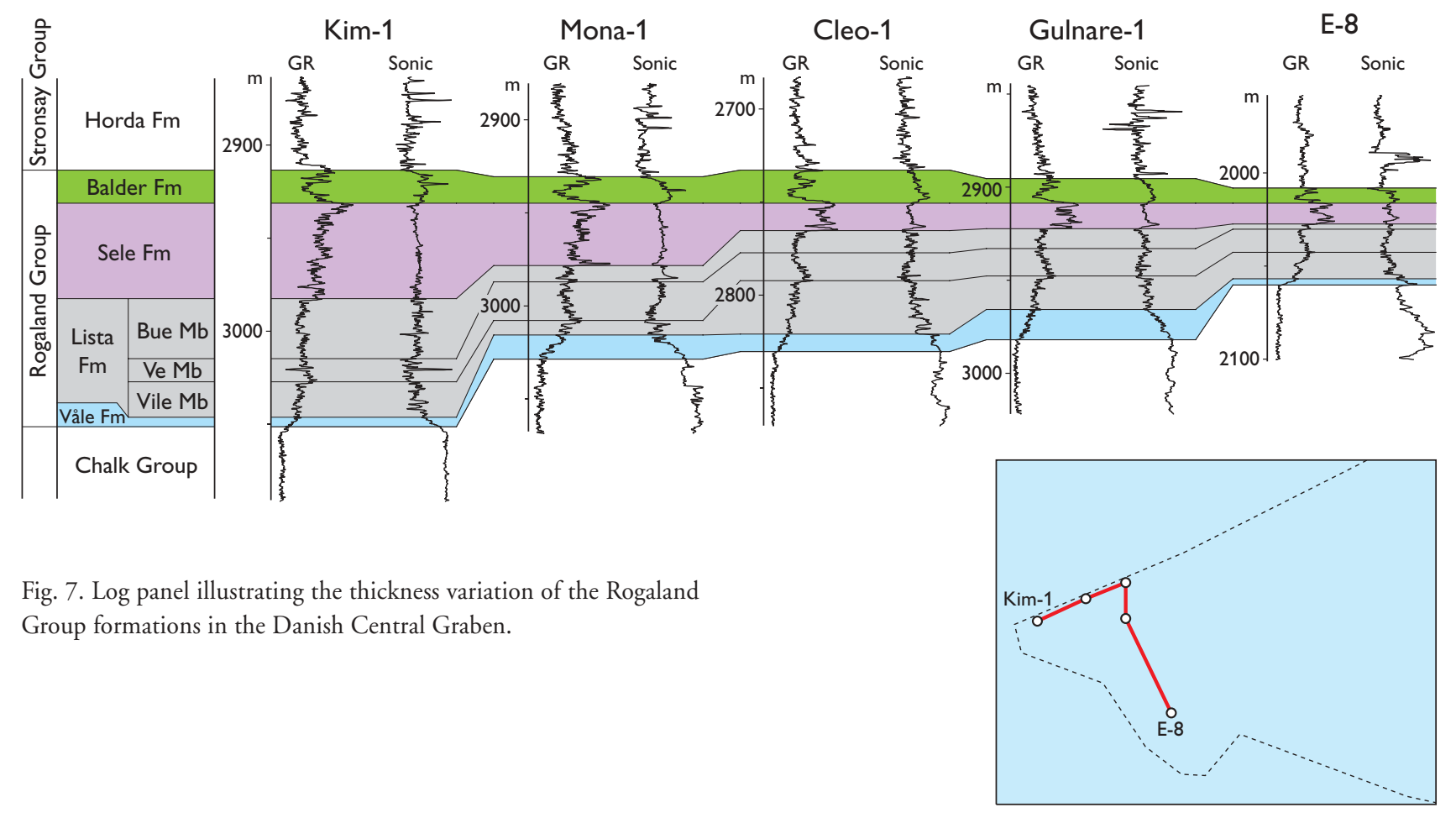

lowermost part of the Haslund Member of the Ølst Formation (Heilmann-Clausen \& Schmitz 2000; Willumsen 2004). In the North Sea Basin, the acme of Apectodinium is located in the lowermost, laminated part of the Sele Formation (sensu Deegan \& Scull 1977, see below) according to Knox (1996). As the event is a LO, its position cannot be determined with certainty in wells in which this interval is covered only by cuttings samples. In the North Sea Basin, however, this stratigraphic level is characterised by a prominent excursion on the gamma-ray log near the base of the Sele Formation which therefore can be used as an approximation for the base of the Eocene Series.

The remaining stages of the Eocene Series, the Ypresian, Lutetian, Bartonian and Priabonian Stages, lack basal boundary GSSPs for the present. In this paper, we follow Mudge \& Bujak (1996b) and approximate the bases of the three latter stages by using three key dinoflagellate events: the base of the Lutetian Stage is at the HO of common Eatonicysta ursulae, the base of the Bartonian Stage is close to the HO of Diphyes colligerum, and the base of the Priabonian Stage is close to the $\mathrm{HO}$ of Heteraulacacysta porosa. The base of the classic Ypresian Stage is at the LO of the calcareous nannoplankton species Tribrachiatus digitalis. As yet, there is no commonly recognised HO index event at that level in the North Sea Basin, but the boundary between the Sparnacian and the Ypresian Stages may be placed below the HOs of com- mon Cerodinium wardenense and Apectodinium augustum (Fig. 5a), both dinoflagellate species.

\section{Oligocene}

The GSSP for the Eocene-Oligocene boundary is in the Massignano section (central Italy), at the highest occurrence of the planktonic foraminifer genera Hantkenina and Cribrohantkenina, immediately above the P17-P18 planktonic foraminifer zone boundary (Premoli Silva \& Jenkins 1993). However, hantkeninids have not been observed from the North Sea Basin and alternative zone markers have therefore been used here. In the North Sea Basin, the planktonic foraminifer Globigerinatheka index and the benthic foraminifer Cibicidoides truncanus have their $\mathrm{HO}$ in the uppermost Eocene (King 1989), and the two events may be used to approximate the Eocene-Oligocene boundary. A palynological marker of the lowermost Oligocene is the $\mathrm{HO}$ of the dinoflagellate Areosphaeridium diktyoplokum (Brinkhuis \& Biffi 1993; Brinkhuis \& Visscher 1995), which is widespread in the North Sea Basin. The three latter events in combination serve as useful markers for bracketing the Eocene-Oligocene boundary in the North Sea Basin.

The principal criterion for the Rupelian-Chattian (Lower-Upper Oligocene) boundary has not yet been de- 


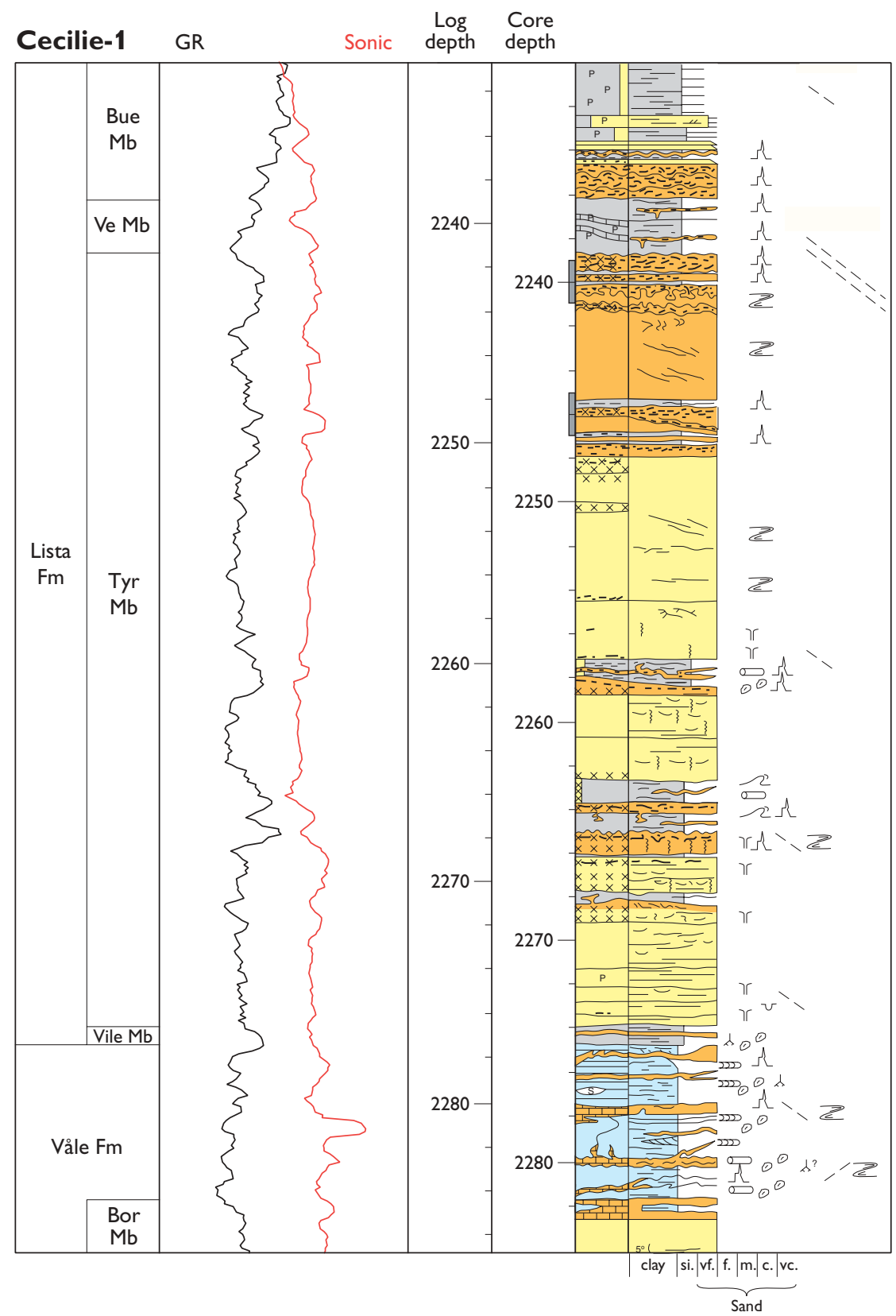

Fig. 8. Core log showing intrusive sandstones in the Våle and Lista Formations in the Cecilie-1 well. For legend, see Fig. 9.

The two intervals marked by grey bars in the core depth column are shown as core photographs in Fig. 10.

cided by the Subcommission on Palaeogene Stratigraphy. Indications are that the boundary may be positioned at the base of the P21b planktonic foraminifer zone (Premoli Silva 2005), at 28.5 Ma (Hardenbol et al. 1998). However, the defining boundary event cannot be recognised in the North Sea Basin and its exact correlation with the North Sea biostratigraphic event succession remains uncertain. Instead, most North Sea biostratigraphers recognise the Rupelian-Chattian stage boundary at the $\mathrm{HO}$ of the benthic foraminifer Rotaliatina bulimoides. This event marks the top of the NSB7 Zone of King (1983, 1989; Fig. 5c) and the NSR7 Zone of Gradstein et al. (1994). The $\mathrm{HO}$ of $R$. bulimoides is at $29 \mathrm{Ma}$ in the northern
North Sea according to Gradstein \& Bäckström (1996), slightly older than the $28.5 \mathrm{Ma}$ for the Rupelian-Chattian stage boundary quoted by Hardenbol et al. (1998). The Rupelian-Chattian stage boundary may also be approximated by the $\mathrm{HO}$ of the dinoflagellate Rhombodinium draco. In the North Sea wells reported herein, where both the HOs of $R$. bulimoides and $R$. draco have been recorded, these events are largely contemporaneous. However, in the type area of the Rupelian and Chattian Stages, $R$. draco has its $\mathrm{HO}$ above $R$. bulimoides in the type Chattian (van Simaeys et al. 2004). Therefore, it may be inferred that the two latter events probably bracket the Rupelian-Chattian boundary (Fig. 5c). 


\section{Miocene}

The Oligocene-Miocene Series boundary is bracketed by a number of HOs at its type section (Lemme-Carosio, north-west Italy). Unfortunately, none of the foraminifer events are believed to be true stratigraphic tops (facies dependent), and reworking in the section hampers the use of nannofossil tops (Steininger et al. 1997). However, the dinoflagellate succession from the Lemme-Carosio section has been documented in detail by Powell (1986), Brinkhuis et al. (1992) and Zevenboom (1995, 1996), and provides a means for direct correlation to the North Sea Basin (Munsterman \& Brinkhuis 2004). The HO of Distatodinium biffii is below the Chattian-Aquitanian boundary in its type section and the $\mathrm{HO}$ of Chiropteridium spp. is above. This succession of events can be recognised in many North Sea wells, and the Chattian-Aquitanian boundary is positioned between the two. Supporting microfossil events that characterise the lowermost Miocene include the $\mathrm{HO}$ of the diatom Aulacodiscus insignis quadrata (small morphotype, same as diatom sp. 3 of King 1983, 1989), a widespread event in the North Sea Basin, and the HO of the benthic foraminifer Brizalina antiqua (King 1989). The HO of the planktonic foraminifer Paragloborotalia nana marks uppermost Chattian strata.
The principal criteria for the Aquitanian-Burdigalian, Burdigalian-Langhian and Langhian-Serravallian stage boundaries are as yet undecided. Most authors place the three boundaries at microfossil zone boundaries or magnetochron boundaries at 20.5, 16.4 and 14.8 Ma, respectively (Hardenbol et al. 1998; Williams et al. 2004). The correlation of the three boundaries to the North Sea Ba$\sin$ is feasible using the dinoflagellate zonation scheme of De Verteuil \& Norris (1996), established for US East Coast sections and the review of dinoflagellate index events published by Williams et al. (2004). The former zonation scheme is correlated directly with the zonation schemes of Berggren et al. (1995) and the Miocene timescale by means of calcareous nannofossils and foraminifers. The Aquitanian-Burdigalian boundary is positioned just above the $\mathrm{HO}$ of the dinoflagellate Caligodinium amiculum. The Burdigalian-Langhian boundary is placed between the $\mathrm{HO}$ of the dinoflagellates Hystrichokolpoma cinctum and Pyxidinopsis fairhavenensis, two events that bracket the boundary level. The Langhian-Serravallian boundary is slightly above the $\mathrm{HO}$ of the dinoflagellate Cousteaudinium aubryae. In this study, these four events have been used to approximate the three stage boundaries.

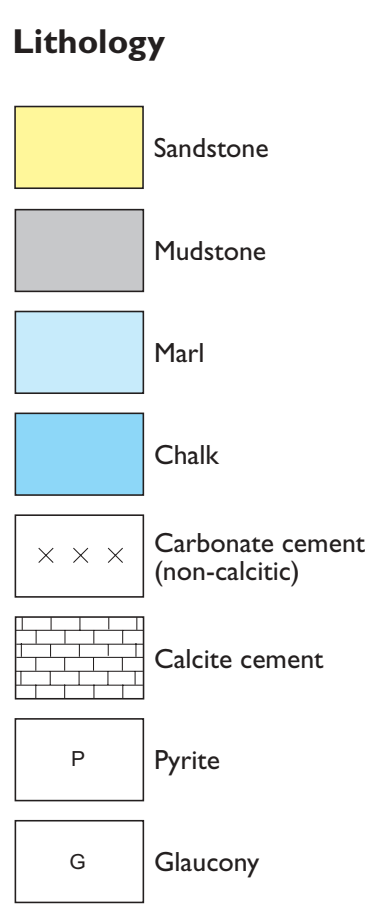

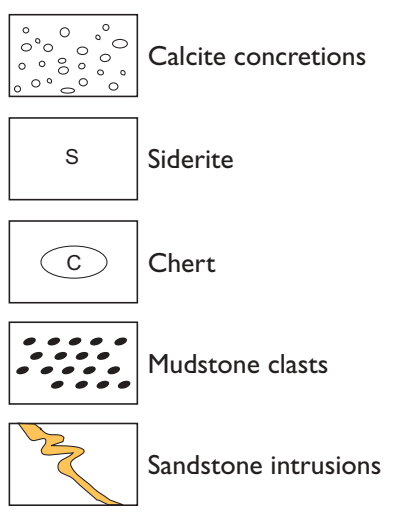

Sedimentary structures

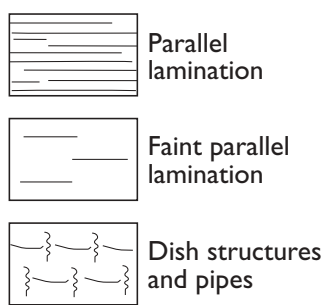

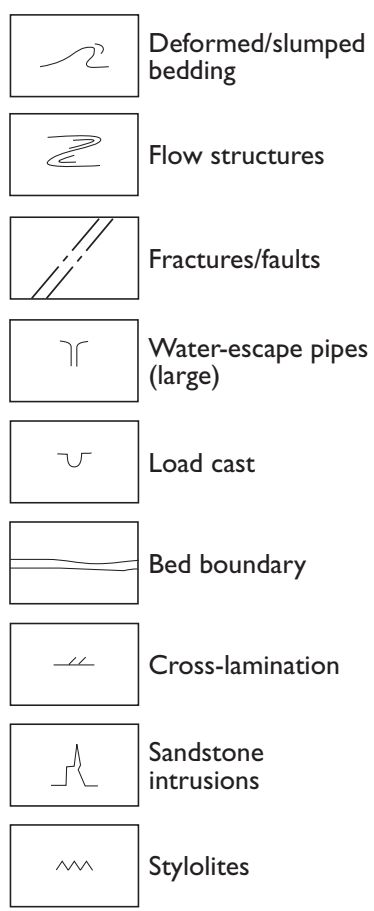

Trace fossils

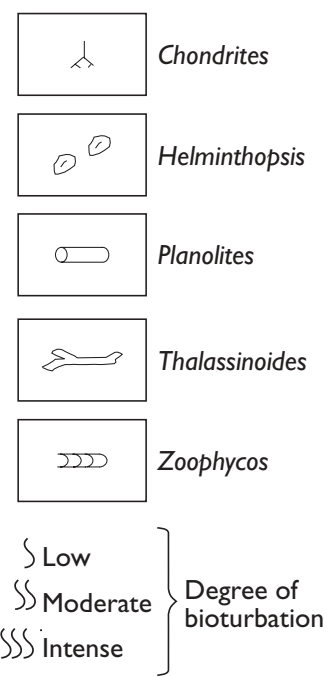

Fig. 9. Legend for core logs (Figs. 8, 11, 18, 27, 30 and 39); the lithological colour scheme is also adopted on well sections (e.g. Fig. 13). 


\section{Lithostratigraphy}

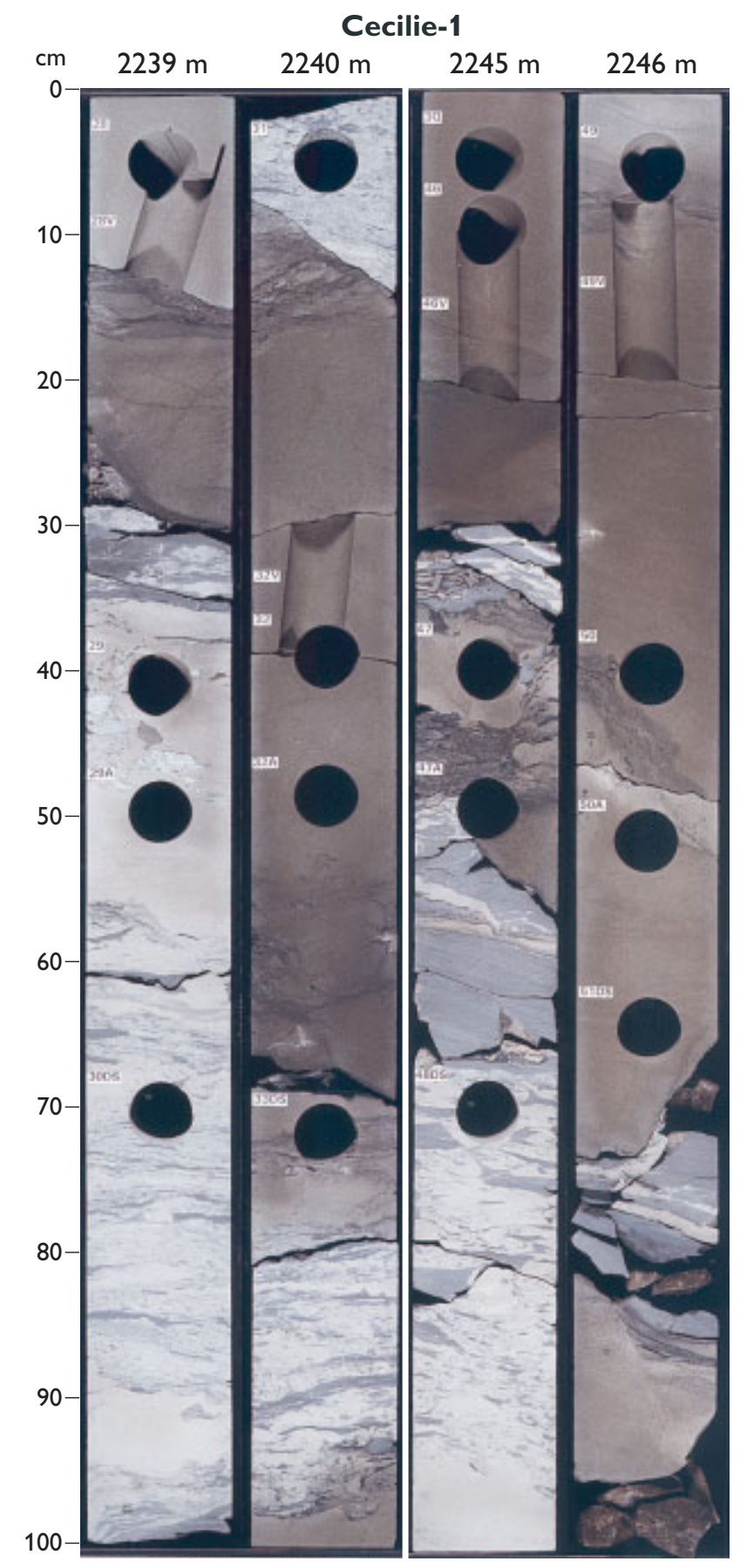

Fig. 10. Core photographs showing dark grey, largely structureless, discordant, intrusive sandstones within the lighter grey mudstones of the upper Tyr Member in the Cecilie-1 well. Depths are core depths. Stratigraphic positions of the figured intervals are shown on Fig. 8.

\section{Rogaland Group}

The Rogaland Group was established by Deegan \& Scull (1977) and comprises the Paleocene to Lower Eocene marlstone and mudstone succession between the top of the Ekofisk Formation of the Chalk Group (Deegan \& Scull 1977) and the glaucony-rich mudstones of the Hordaland Group (now Stronsay and Westray Groups) in the central North Sea. In most of the Danish sector, the Rogaland Group has a relatively uniform thickness and comprises the Våle, Lista, Sele and Balder Formations (Fig. 7). The Fur Formation is a part of the Rogaland Group and is present in a limited area in the north-eastern part of the Danish sector of the North Sea stretching into the Norwegian sector. Hardt et al. (1989) added three new sandstone units to the Rogaland Group in the southern Viking Graben (Norwegian sector): Ty Formation, Heimdal Formation and Hermod Formation (Fig. 4). Although these sandstone units are broadly comparable to coeval sandstone units encountered in the Siri Canyon System (Figs 1, 4) in the Danish sector, the Norwegian units and the Siri Canyon sandstones have different provenances and are not contiguous with each other. Therefore, the sandstone units in the Danish sector are described herein as new members.

In the Siri Canyon (Fig. 1), the mudstones of the Rogaland Group contain concordant or discordant postdepositional sandstone intrusions (Hamberg et al. 2005). In some wells (e.g. Cecilie-1 and Nini-3) sandstone intrusions are very common (Figs 8-11). The sands have intruded most levels in the Rogaland Group, but the Ve Member (new member of the Lista Formation, see below) in the middle part of the group is particularly rich in intrusions. Most of the intrusive sandstones are only a few millimetres thick, but they may reach a thickness of $5 \mathrm{~m}$. In some wells they constitute up to $30 \%$ of the total sandstone thickness. The intrusions are usually massive, but faint lamination is locally present, especially at the top of the beds. Most of the intrusive sandstone bodies are separated by in situ mudstones, but they may also occur in intervals showing multiple intrusions. The boundaries with the host rock are slightly to very irregular or wavy, and in places discordant. Minor intrusive offshoots (apophyses) into the host rock are common. The petrography of the intrusive sandstones is similar to that of the in situ sandstones and they are therefore most likely sourced from the 
Fig. 11. Core log showing intrusive sandstones in the Vile and Idun Members in the Nini-3 well. For legend, see Fig. 9. The two intervals marked by grey bars in the core depth column are shown as core photographs in Fig. 12.

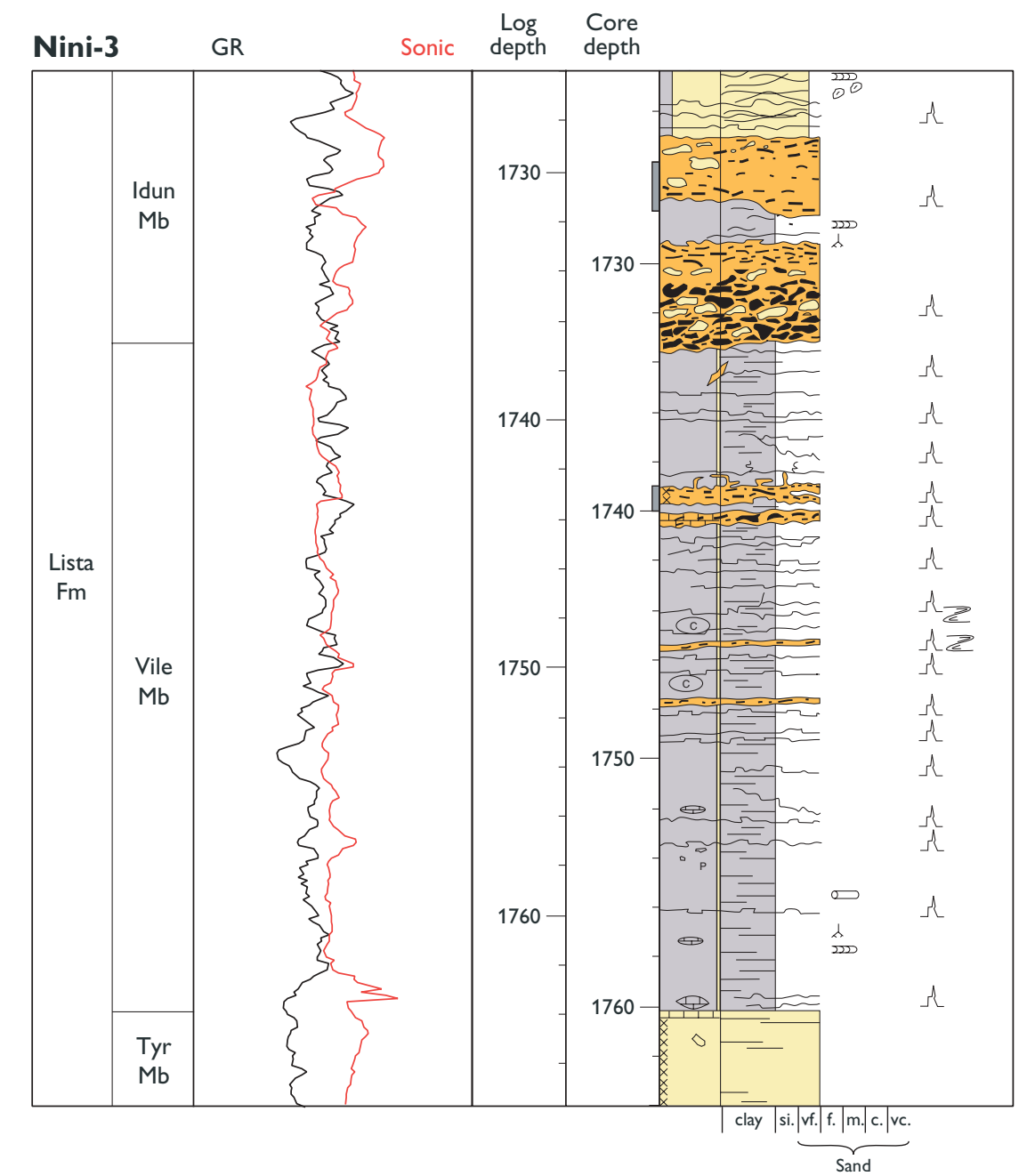

tures are occasionally present. Top-bed rip-down mudstone clasts (Stow \& Johansson 2000) are common (Fig. 12). Fossil wood fragments are present, but rare.

As the distribution of intrusive sandstones is the result of postdepositional rather than synsedimentary processes, they may cross lithostratigraphic boundaries. When an injected sandstone body occurs in direct contact with an in situ sandstone unit (e.g. as seen in the higher parts of the new Tyr Member in Fig. 8), it is impossible to distinguish between the two genetically different units on the basis of petrophysical logs and cuttings samples alone; only a sedimentological study of core material may reveal the different nature of the two sandstones.

\section{Våle Formation}

History. The Våle Formation was established by Hardt et al. (1989) for the marls with interbedded claystones, limestones and silt- and sandstone stringers that overlie the Chalk Group in the central and northern North Sea. The 


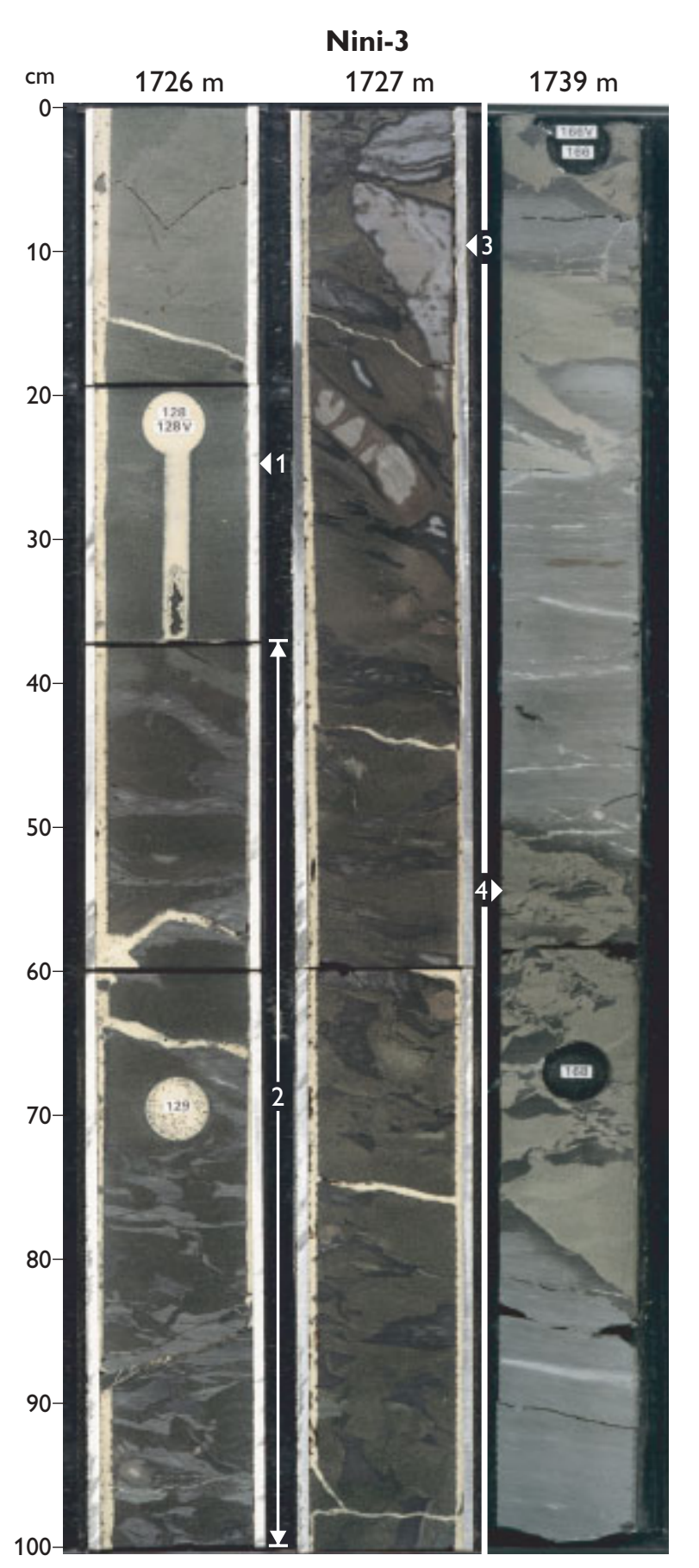

Fig. 12. Core photographs of the Vile and Idun Members in the Nini3 well showing sandstone intrusions, weak flow banding (1), injection breccia with abundant irregular and angular clasts (2), mudstone clasts in injected sand (3) and top bed rip-down clasts (4). Depths are core depths. Stratigraphic positions of the figured intervals are shown on Fig. 11.

presence of a marly succession on top of the Chalk Group was previously noted by Deegan \& Scull (1977) and treated informally as an equivalent to the more coarse-grained Maureen Formation in the UK sector of the North Sea.

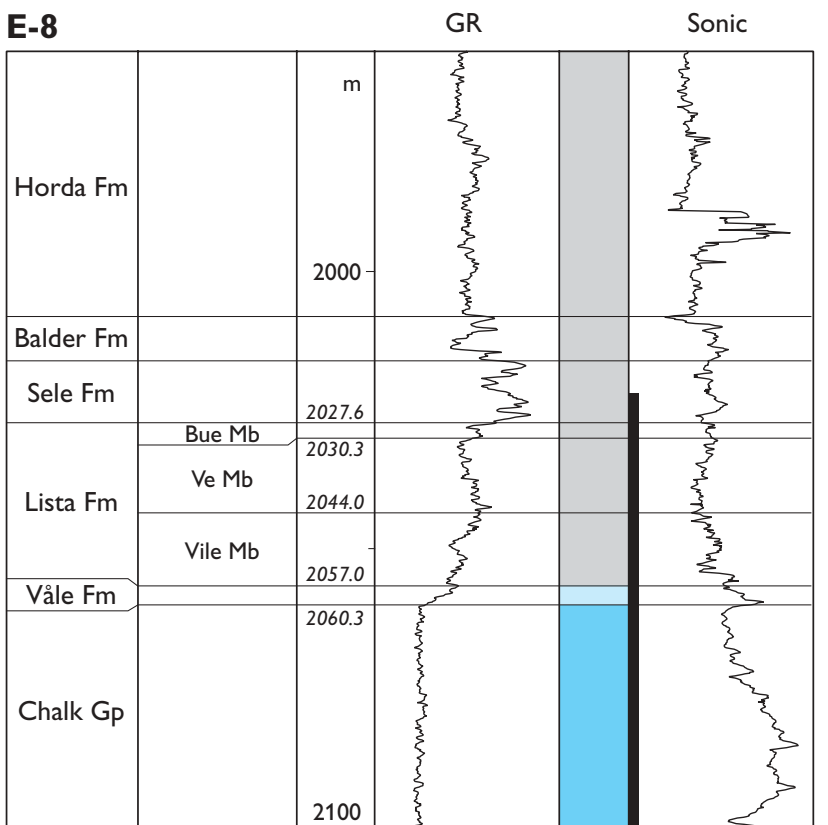

Fig. 13. E-8, Danish reference well for the Våle and Lista Formations, and reference well for the Vile, Ve and Bue Members. Black bar shows cored section.

Kristoffersen \& Bang (1982) established the North Sea Marl for an exclusively marly and calcareous unit corresponding to the Maureen Formation-equivalent unit of Deegan \& Scull (1977). Although the description of the North Sea Marl fulfils the requirements for a formal description of a lithostratigraphic unit (with the exception of lacking indication of the rank of the unit), they specifically stated that their unit was only informally established. The name North Sea Marl has only rarely been used outside the Danish sector of the North Sea; the sediments are instead referred to the Våle Formation, which covers most national sectors of the North Sea Basin. As doubt may be raised about the formal status of the North Sea Marl unit, and in order to promote communication between North Sea stratigraphers, it is considered by the present authors that the Vale Formation of Hardt et al. (1989) serves as the better name for the marlstone unit.

Type well. Norwegian sector well 1/3-1, 3258-3209 m MDKB.

Danish reference wells. E-8, 2060.3-2057.0 m MDKB (Fig. 13); Siri-1,2186.5-2156.3 m MDKB (Fig. 14; Plates 1, 4).

Distribution and thickness. The Vàle Formation and its equivalents are present throughout the North Sea Basin, except in a few areas where their absence is due to nondeposition or erosion. The Våle Formation is absent on 
Fig. 14. Siri-1, Danish reference well for the Våle and Sele Formations. Black bars show cored sections.

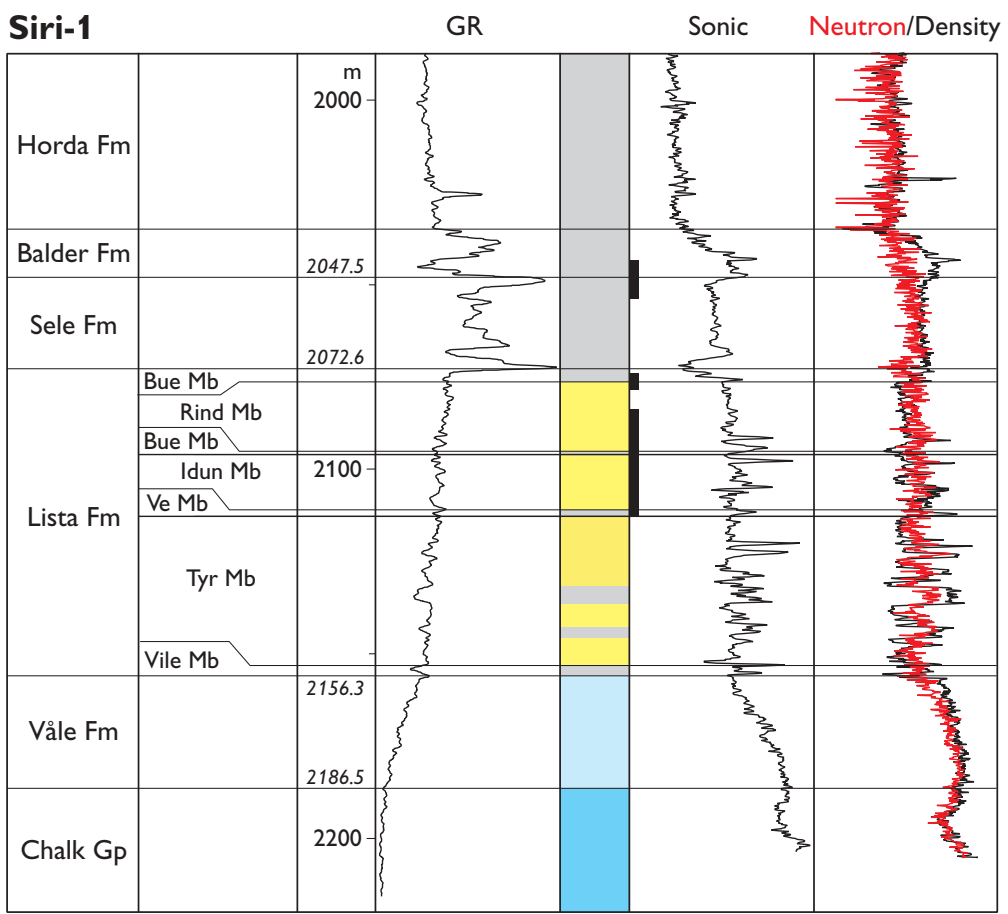

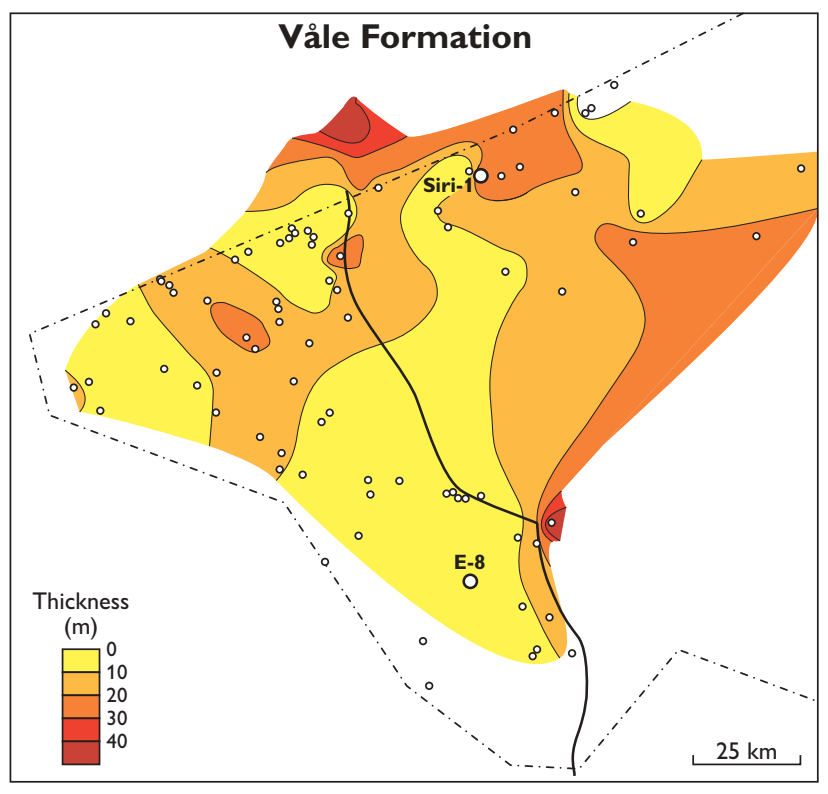

Fig. 15. Isochore map of the Våle Formation in the study area. The positions of the two Danish reference wells, E- 8 and Siri-1, are indicated on the figure.

intrabasinal highs (Hardt et al. 1989) and in parts of the Siri Canyon where the Rogaland Group overlies the Chalk Group with an erosional unconformity. Its thickness varies from 0 to $48 \mathrm{~m}$ in the Danish sector of the North Sea (Fig. 15).

Lithology. Light grey to greenish grey, heavily bioturbated pyrite-bearing marlstones dominate the formation (Fig. 16). Thin sandstone intrusions are present locally. In the Siri Canyon, the marls are interbedded with turbidite sandstones; where sandstone-dominated, the succession is referred to a new member (Bor Member, defined below).

Log characteristics. From its base to its top, the Våle Formation is characterised by an overall steady increase in gamma-ray response, combined with an overall steady decrease in sonic readings. When the Bor Member sandstones are present, blocky log signatures with higher gamma-ray values and lower sonic readings interrupt this general trend (Fig. 17).

Boundaries. In most wells in the Danish sector, the change from the chalks of the Chalk Group to the marlstones of the Vale Formation is gradational and the boundary can be difficult to position (Fig. 16). In the Siri Canyon, however, most wells show an erosional contact between the Chalk Group and the Vale Formation and the formation boundary is sharp. On the petrophysical logs, the boundary is placed where the stable, low gamma-ray response characteristic of the Ekofisk Formation starts to increase upwards and the high sonic readings (also characteristic of the latter formation) start to decrease upwards. The change in the log pattern may be stepwise with each step represented by a small increase in gamma-ray values and an accompanying decrease in sonic readings. The Våle Formation is overlain by the Lista Formation. 


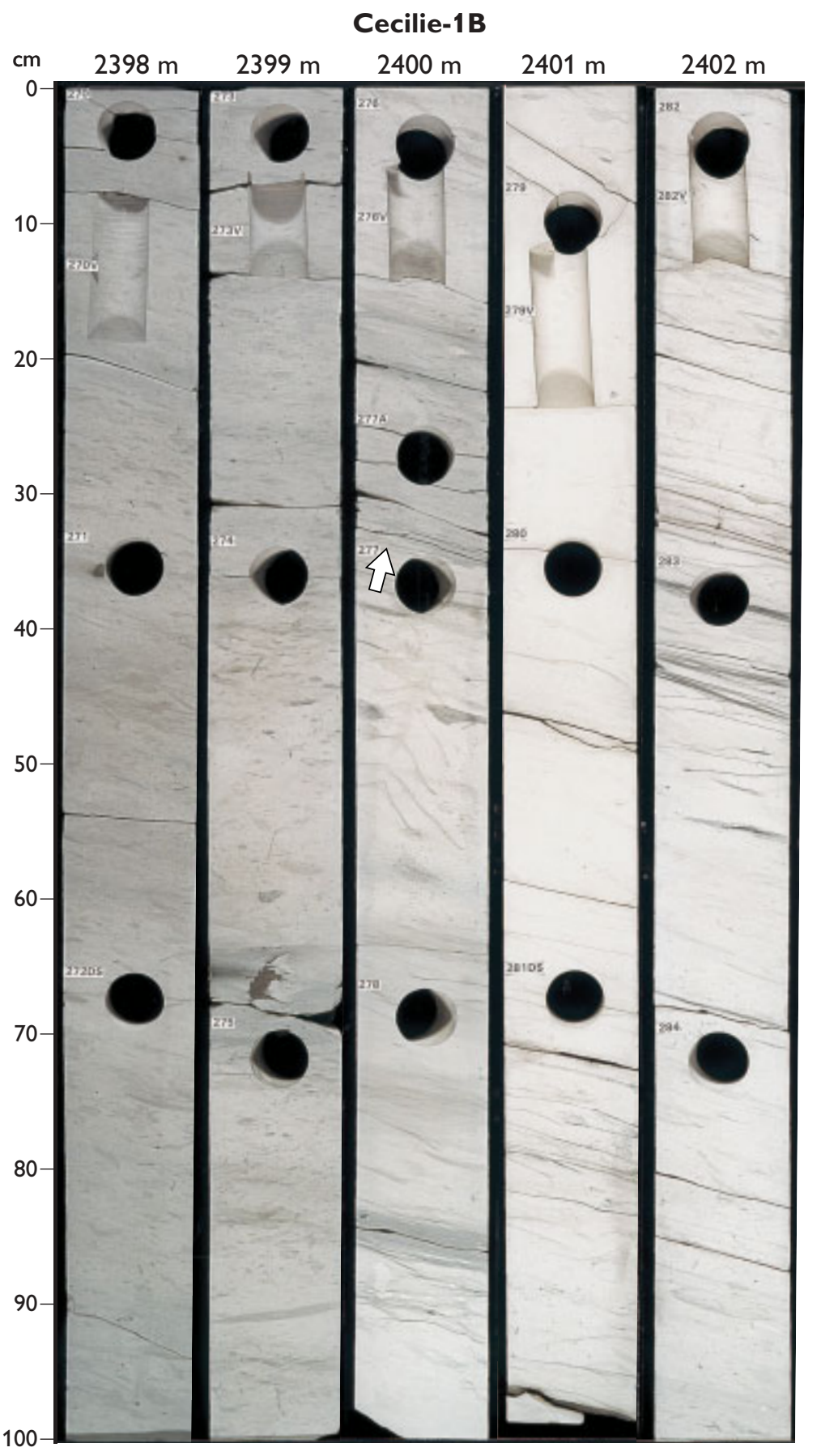

Fig. 16. Core photographs of the Ekofisk-Våle formation boundary in the Cecilie-1B well. The shift from chalk to marlstones is gradational and placing the boundary can be difficult; it is positioned in the middle part of the core interval $2400.00-2401 \mathrm{~m}$, at $2400.35 \mathrm{~m}$ (arrow), where light grey marls become dominant. Depths are core depths.

Subdivision. The Våle Formation includes a sandstone unit (Bor Member, new) in the Danish North Sea sector.

Macro- and ichnofossils. Fragments of shelly macrofossils are present, but rare. The Våle Formation is heavily bioturbated. Trace fossils in the formation include Chondrites ispp., Phycosiphon ispp., Planolites ispp. and Zoophycos ispp. Thalassinoides ispp. burrows are only present locally.

Microfossils and palynomorphs. The uppermost part of the underlying Ekofisk Formation is characterised by the $\mathrm{HO}$ of the dinoflagellate Senoniasphaera inornata followed uphole by the $\mathrm{HO}$ of the planktonic foraminifer Globoconusa daubjergensis. There is a hiatus at the contact between the Ekofisk and Vale Formation in many sections and wells (Clemmensen \& Thomsen 2005). The basal part of the Våle Formation, just above the top of the Ekofisk Formation, is marked by the downhole increase in calcareous foraminifer diversity and the $\mathrm{HO}$ of the planktonic foraminifers Globanomalina cf. compressa and Subbotina 
Fig. 17. Augusta-1, type well for the Bor, Ve and Bue

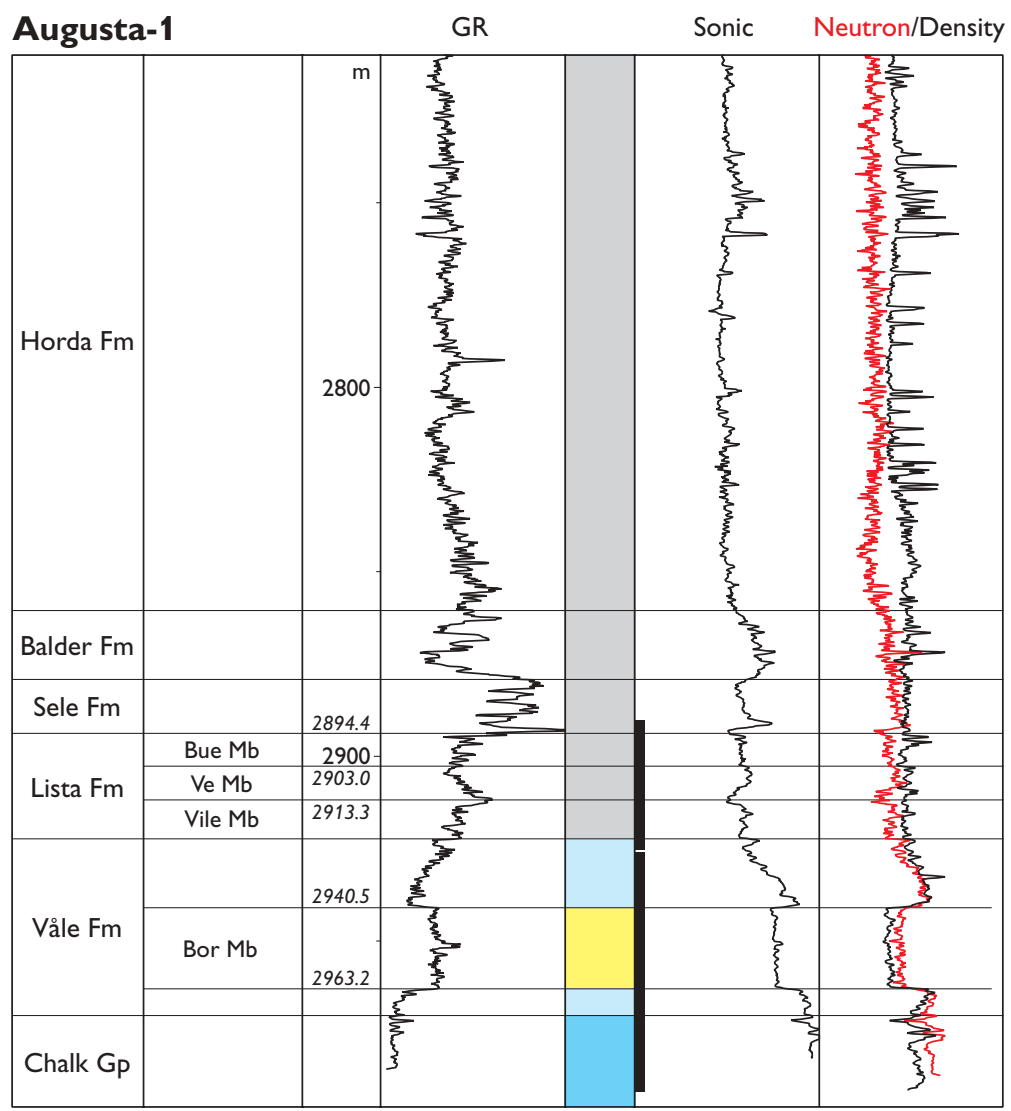

Members. Black bars show cored sections.

trivialis. Thus, the boundary between the two formations may in practice be located by reference to these three events (Fig. 5a). The $\mathrm{HO}$ of the dinoflagellate Alisocysta reticulata marks a level in the lower part of the Vale Formation. Calcareous microfossil events near the top of the Våle Formation in the Danish sector include the provisional $\mathrm{HO}$ of planktonic foraminifers.

Depositional environment. Over most of the Danish sector, the marlstones of the Vale Formation comprise hemipelagic deposits and deposits from dilute turbidity currents. The marlstones are probably largely of turbiditic origin. The foraminifer fauna of the Våle Formation is characterised by common calcareous taxa. Taxa belonging to the neritic 'Midway-type' fauna (Berggren \& Aubert 1975) are especially common. The plankton/benthos ratio varies from approximately $1: 1$ in some areas to a total dominance of calcareous benthic foraminifers in other areas. The microfaunal composition indicates that the Vale Formation was deposited in an open marine, outer neritic environment that periodically reached upper bathyal depths. The bottom conditions were predominantly oxic with periods of dysoxia. The indications from the microfauna are supported by the trace fossil assemblage, which indicates water depths of at least $200 \mathrm{~m}$ combined with oxic to dysoxic bottom conditions. In the Siri Canyon, where thin turbidites are common in the Våle Formation, gravity flows played a major role during the deposition of the formation.

Age. Selandian.

Correlation. The Vàle Formation is equivalent to the Lellinge Greensand and the Kerteminde Marl onshore Denmark and lithologically most closely resembles the latter. The oldest part of the Kerteminde Marl and the Lellinge Greensand are coeval, but the latter has a more restricted distribution (Sjælland and Storebælt regions only, Fig. 1; Thomsen 1994; Clemmensen \& Thomsen 2005). Alisocysta reticulata is consistently present in the lowest part of the Kerteminde Marl (Clemmensen \& Thomsen 2005). The $\mathrm{HO}$ of $A$. reticulata is therefore an important intraVåle as well as intra-Kerteminde Marl marker that may be used to correlate the two formations. The Vale Formation correlates with the marly facies of the Maureen Formation in the UK and Norwegian sectors of the Central and Viking Grabens (Knox \& Holloway 1992). 


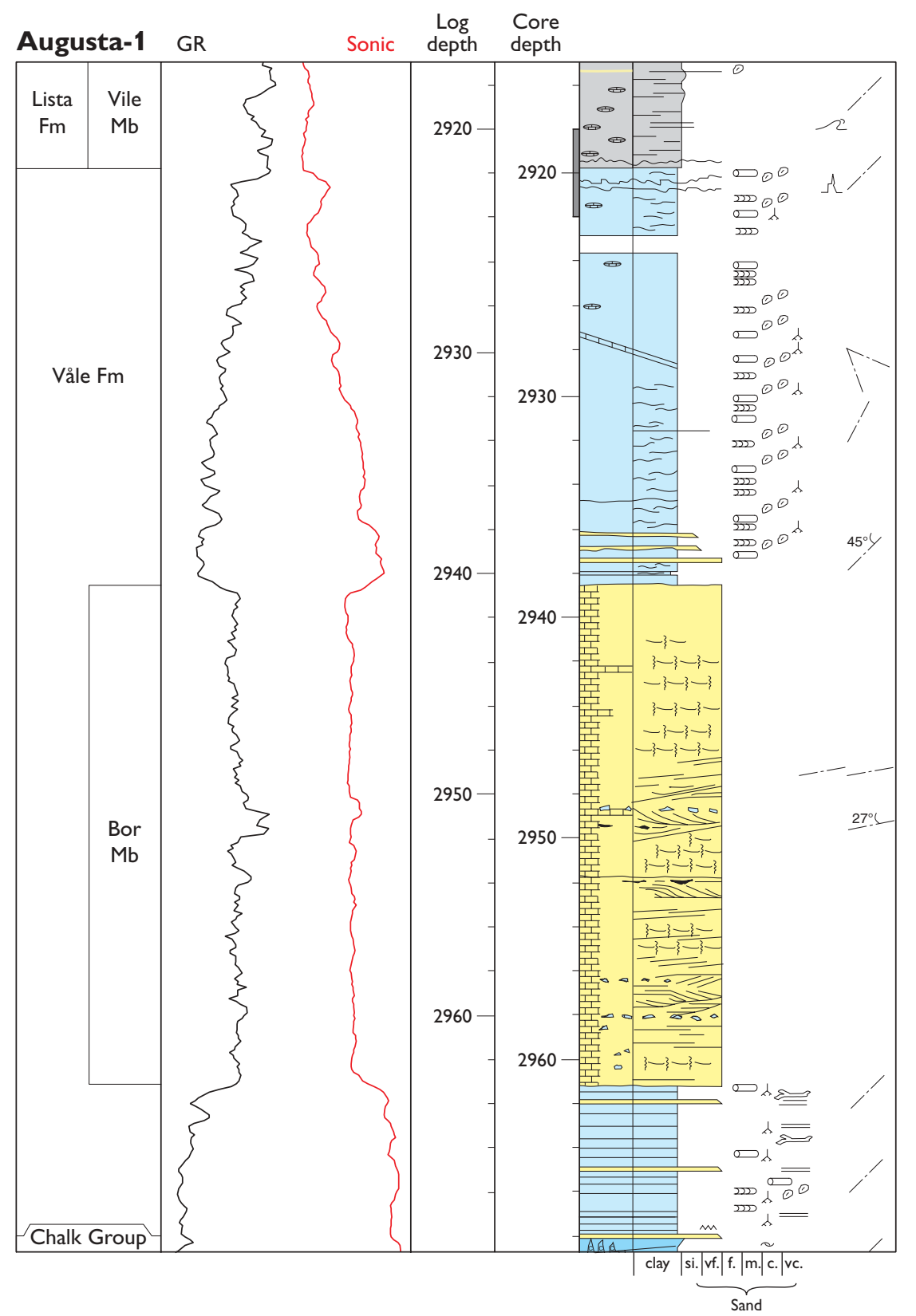

Fig. 18. Core log of Bor Member sandstones in the Augusta-1 well. Legend in Fig. 9. The interval around the Våle-Lista formation boundary marked by a grey bar in the core depth column is shown as core photographs in Fig. 23.

\section{Bor Member}

new member

History. The Bor Member encompasses sandstone bodies enveloped in the marlstones of the Vale Formation in the Danish North Sea sector. Hardt et al. (1989) recognised a pure sandstone unit, the Ty Formation, located between the Ekofisk and Lista Formations in the southern Viking Graben. The Ty Formation replaces the Våle Formation in its occurrence area and may be contemporaneous with the Bor Member, but it is not contiguous with it and it has a different source area. The presence of sandstone bodies in the Våle Formation in the Danish sector was recognised by a stratigraphic working group at Statoil
Norway in the mid-1990s and the sandstones were informally named the 'Borr Member'.

Derivation of name. After Bor (Danish spelling), the father of Odin.

Type well. Danish sector well Augusta-1, 2963.2-2940.5 m MDRT (Figs 17, 18).

Reference well. Danish sector well Cecilie-1, 2319.6-2284.6 m MDRT (Fig. 19).

Distribution and thickness. The Bor Member has been encountered at the mouth of the Siri Canyon as well as in 
Fig. 19. Cecilie-1, reference well for the Bor and Tyr Members. Black bar shows cored section.

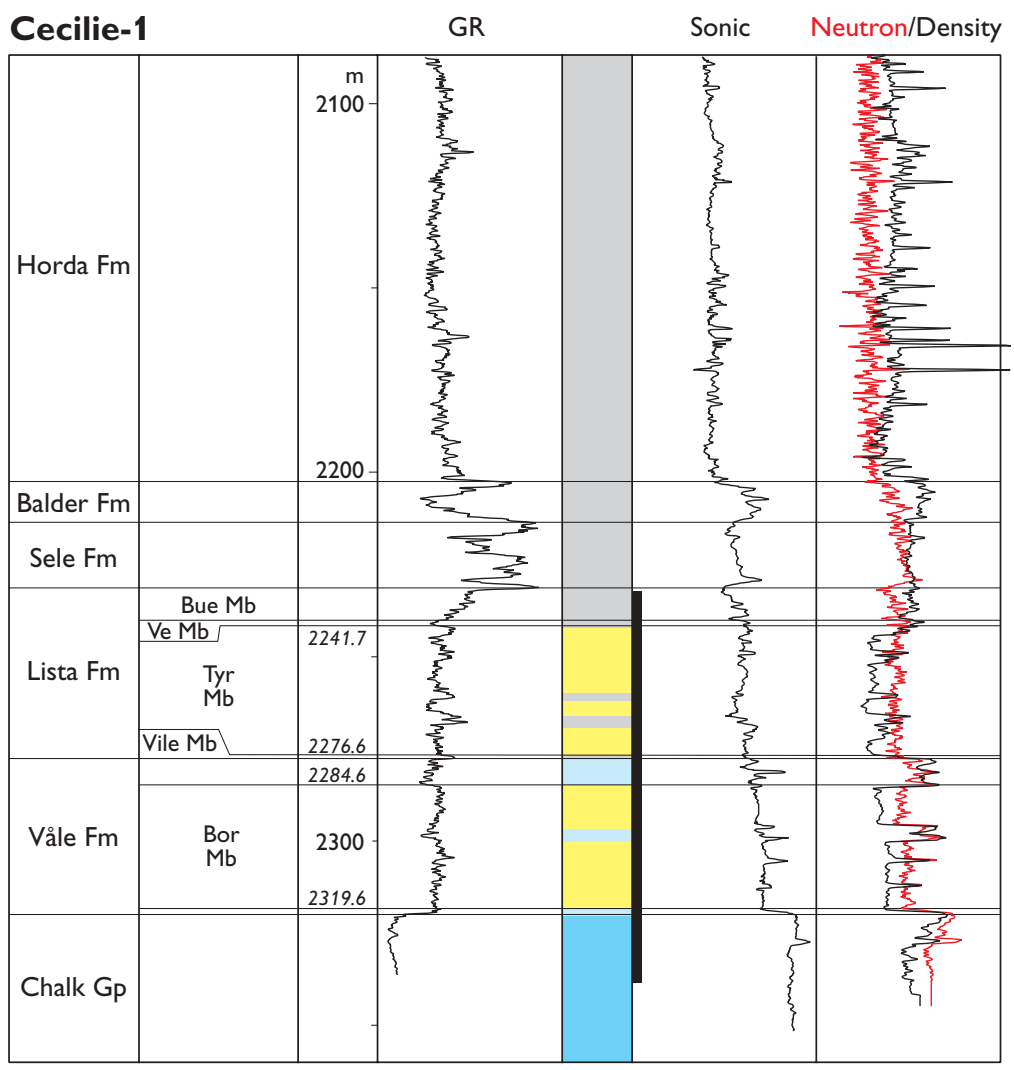

the nearby wells Tabita-1, Augusta-1 and Cleo-1 (Fig. 20a; Plate 1). It reaches a thickness of up to $23 \mathrm{~m}$.

Lithology. The Bor Member consists of olive-green, partly calcite-cemented sandstones. The sandstones are very fine grained to fine grained and well sorted (Fig. 18). Rounded and translucent quartz grains dominate, but the content of glaucony grains is high (20-25\%). Mica and pyrite concretions are present in small amounts. Angular chalk and claystone clasts occur locally. Although composed exclusively of sandstone in the type well (Fig. 18), the member may also include subordinate interbedded marlstones (e.g. Cecilie-1, Fig. 19).

Log characteristics. The Bor Member sandstones are best identified on the density log where they produce a blocky pattern with density values significantly lower than those of the marlstones beneath and above. The sandstones may also be identified from a combination of the density and neutron logs, as the presence of pure sandstone results in a 'cross-over' of the two log curves (Figs 17, 19). On the gamma-raylog, the Bor Member is characterised by a blocky log signature with only small-scale increasing or decreasing trends and with values clearly higher than those of the subjacent, suprajacent and locally interbedded marlstones.
Boundaries. The boundaries with the marlstones of the Våle Formation, the chalks of the Ekofisk Formation and the mudstones of the Lista Formation are sharp and characterised by prominent shifts on the gamma-ray, sonic and density logs (Figs 17-19, 21).

Depositional environment. The sandstones of the Bor Member were deposited from highly concentrated gravity flows at bathyal depths.

Age. Selandian.

Correlation. The Bor Member is contemporaneous with parts of the Kerteminde Marl onshore Denmark. The Lellinge Greensand, which appears between the top chalk surface and the Kerteminde Marl in some areas in eastern Denmark, may also be broadly contemporaneous with the Bor Member, but differs from it lithologically in being predominantly a glaucony-rich calcilutite, rich in bryozoan fragments. The Bor Member may be compared with the Ty Formation (Hardt et al. 1989) and with sandstones in the Maureen Formation (Deegan \& Scull 1977) in the Norwegian and UK sectors of the southern Viking Graben and the Central Graben. However, it is not contiguous with these units and it has a different source area. 

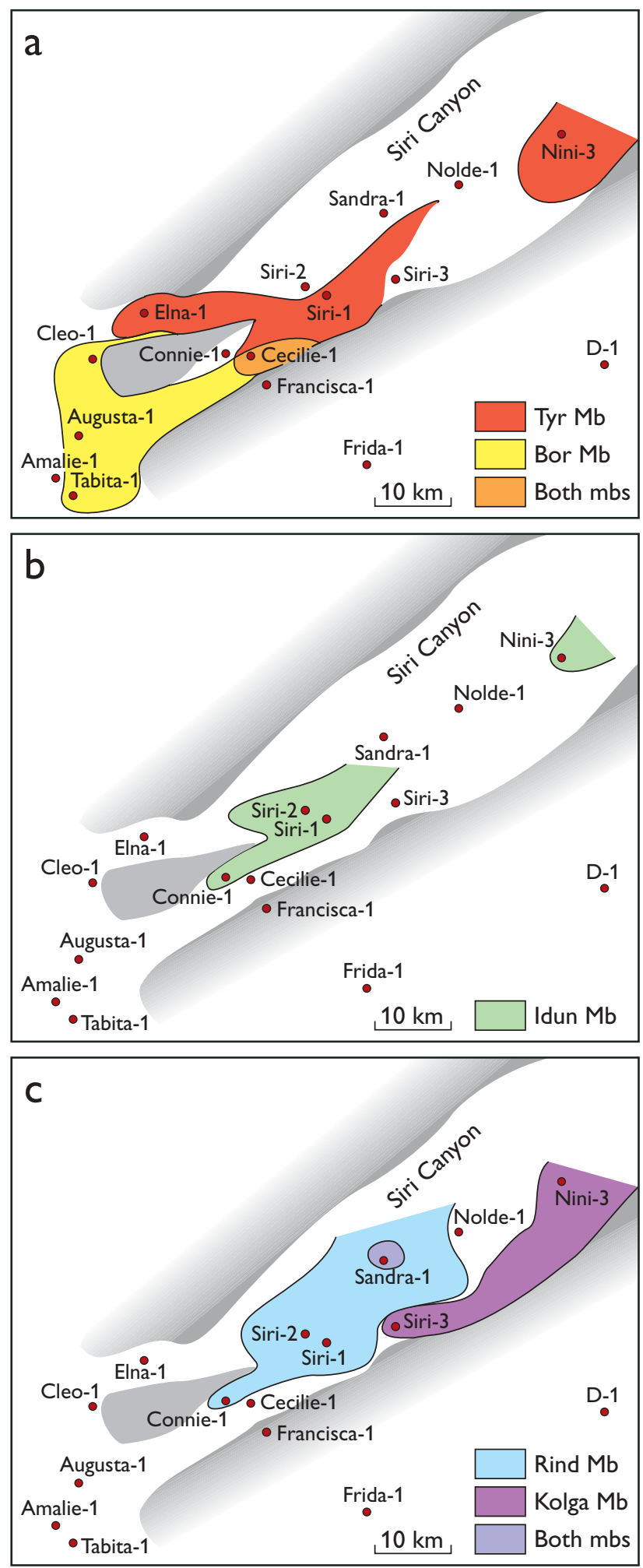

Fig. 20. Location map showing the distribution of the Rogaland Group sandstones in the Siri Canyon (the outline of the canyon is indicated by grey shading, the grey shading inside the canyon indicates an area of positive relief within the canyon). a: Bor and Tyr Members. b: Idun Member. c: Rind and Kolga Members.

\section{Lista Formation}

History. Deegan \& Scull (1977) established the Lista Formation for the widespread, non-laminated mudstones that overlie the marls of the unit equivalent to the Maureen Formation (Våle Formation). Kristoffersen \& Bang (1982) established the non-calcareous clay and shale unit CEN-1 between the top of their North Sea Marl (Våle Formation) and the base of the beds with volcanic tuff. They noted that the CEN-1 unit corresponds to the Lista Formation. For reasons of seniority and the informal nature of the CEN units, we maintain the name Lista Formation for this stratigraphic unit.

Type well. Norwegian sector well 2/7-1,2917.5-2872.5 m MDKB.

Danish reference wells. E-8, 2057.0-2027.6 m MDKB (Fig. 13); Cleo-1, 2812.0-2765.5 m MDKB (Fig. 21; Plate 1).

Distribution and thickness. The Lista Formation is present throughout the North Sea Basin, except in a few areas where it has been removed by erosion. In the Danish sector, its thickness varies from 0 to $108 \mathrm{~m}$ (Fig. 22).

Lithology. The formation is characterised by dark coloured, predominantly greyish, greenish or brownish, non-laminated to faintly laminated, non-calcareous mudstones. The Lista Formation is predominantly non-tuffaceous but becomes tuffaceous towards its top. In the Siri Canyon, glaucony-rich, massive sandstone layers and injected sandstone bodies occur in the Lista Formation.

Log characteristics. Although fluctuating, both the gamma-ray and sonic log readings in the Lista Formation have higher mean values than those of the underlying Vale Formation and lower mean values than those of the overlying Sele Formation. In wells where mudstone facies dominate in the Lista Formation, the gamma-ray and sonic log patterns can be subdivided into three. The tripartite $\log$ pattern reflects the succession of three different mudstone units, established as new members herein (see below).

Boundaries. In most wells where the transition has been cored, the boundary is sharp between the light-coloured marlstones of the Vale Formation and the dark-coloured, non-calcareous mudstones of the lower Lista Formation (Vile Member, see below; Fig. 23). On the gamma-ray $\log$, the boundary is picked at an abrupt upward shift to higher values than in the underlying Våle Formation. This level can typically be identified on the soniclog at a velocity 
Fig. 21. Cleo-1, Danish reference well for the Lista Formation and the Vile, Ve and Bue Members.

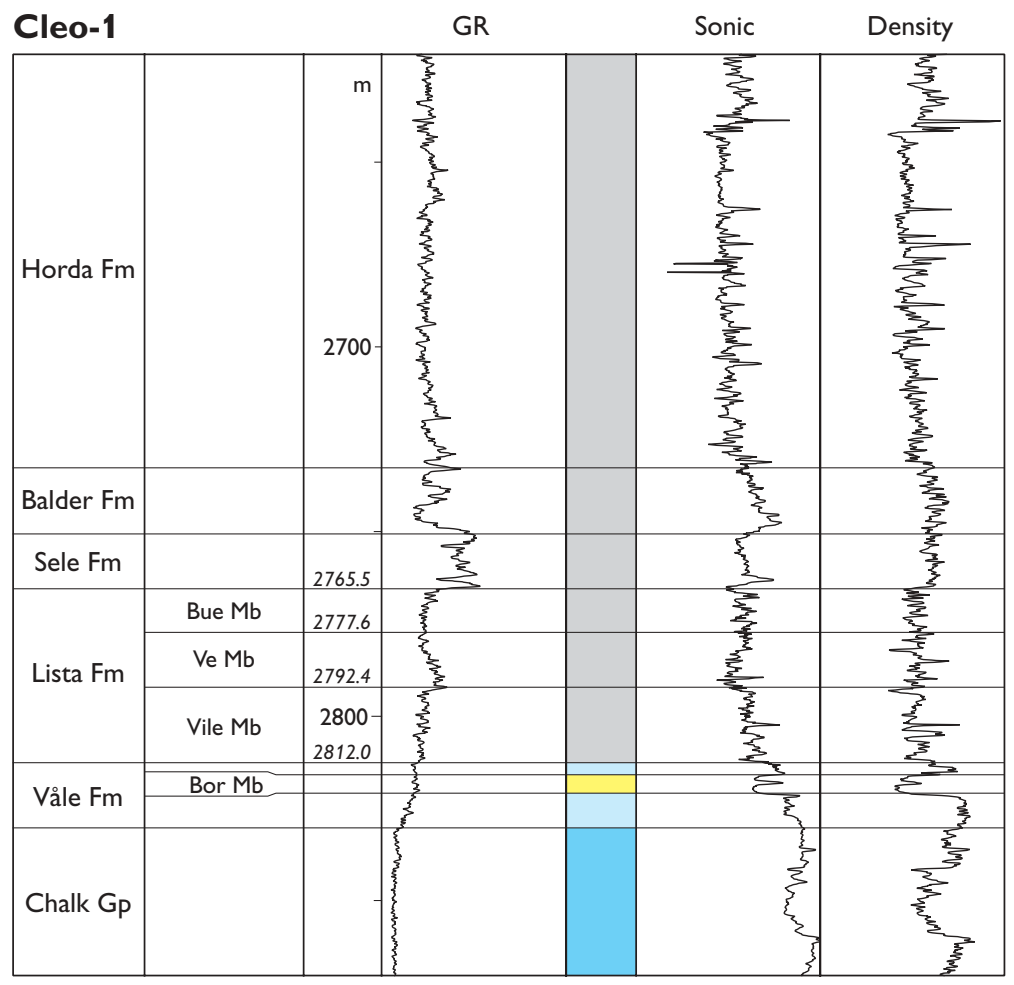

minimum. Above this minimum, the sonic readings increase slightly upwards.

The Lista Formation is overlain by the Sele Formation. The base of the Sele Formation was defined by Deegan $\&$ Scull (1977 p. 34) at the contact between "non-laminated, non-tuffaceous shales" (Lista Formation) and "laminated tuffaceous shales" (Sele Formation). This boundary definition was followed by Mudge \& Copestake (1992a, b). On the other hand, Knox \& Holloway (1992 p. 46) followed O'Connor \&Walker (1993) and placed the boundary somewhat lower, at the contact between "grey-green and green-grey, blocky, bioturbated claystones" of the Lista Formation and "dark grey fissile mudstones" of the Sele Formation. The boundary concept of Knox \& Holloway implies that the "non-laminated, non-tuffaceous shales" of Deegan \& Scull are incorporated in the Sele Formation where these, together with overlying laminated indisputable Sele mudstones, constitute the basal Sele unit S1a (Knox \& Holloway 1992). In the present paper, the boundary concept of Deegan \& Scull (1977) is followed, and the lower part of the unit of "non-laminated, nontuffaceous shales" (the "dark grey, fissile mudstones" of Knox \& Holloway) that overlies the grey-green mudstones is retained in the Lista Formation as its topmost unit. This unit is formalised as a new member of Lista Formation herein (Bue Member, see below).

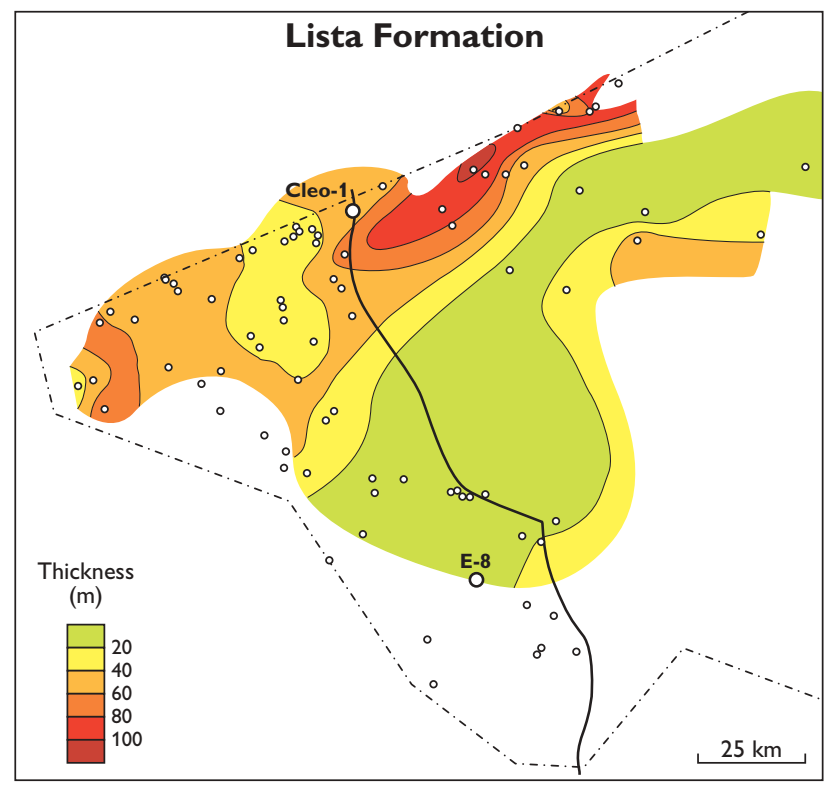

Fig. 22. Isochore map of the Lista Formation in the study area. The positions of the two Danish reference wells, Cleo-1 and E-8, are indicated.

Subdivision. The Lista Formation is subdivided into six new members. Three of these, the Vile, Ve and Bue Members, are mudstone units that have widespread distribution in the North Sea Basin and can be correlated with Danish onshore units. In the Siri Canyon, fine-grained 


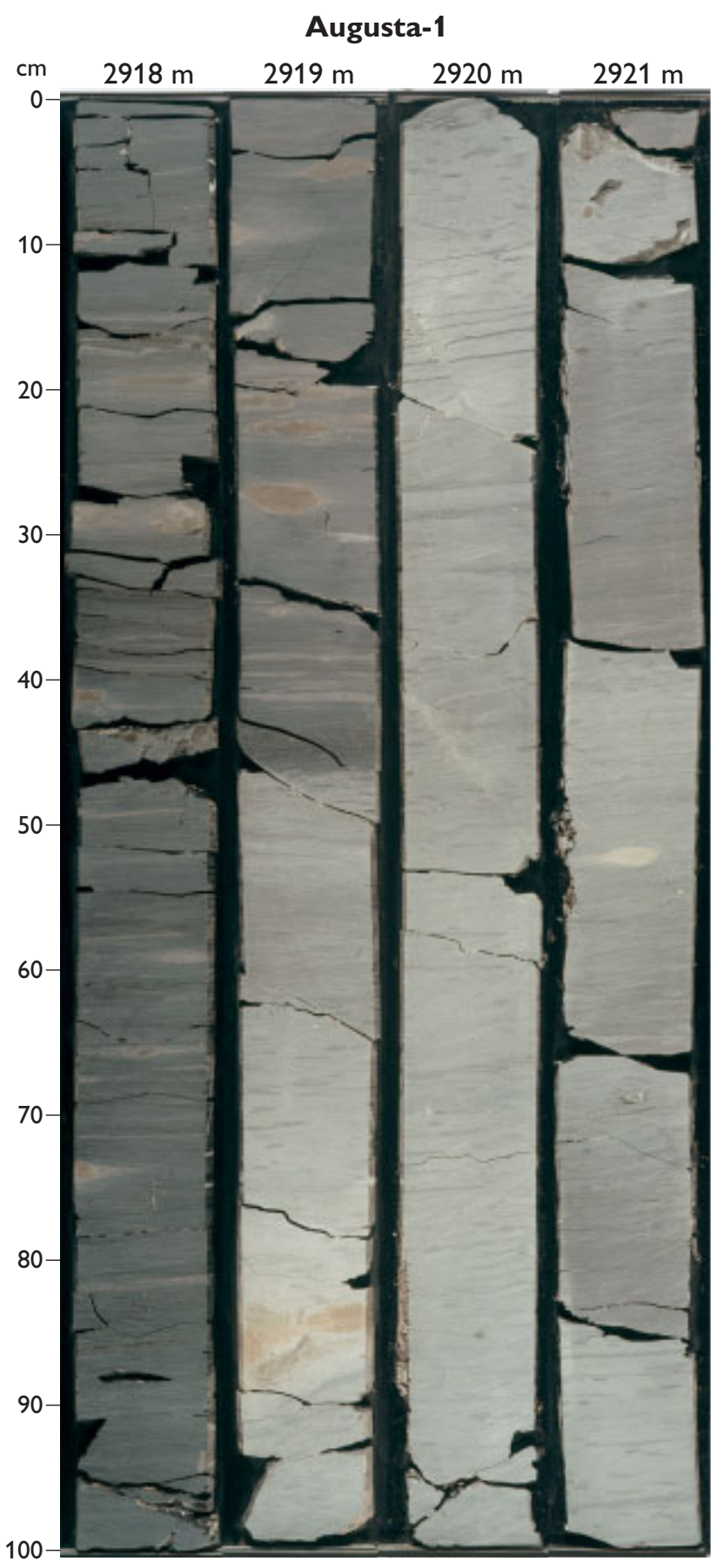

Fig. 23. Core photographs of the Våle-Lista formation boundary interval in the Augusta-1 well. The boundary is at $2919.46 \mathrm{~m}$ where dark grey non-calcareous mudstones of the Vile Member overlie greenish grey marls of the Våle Formation. In most cores the boundary is sharp, as illustrated here. Depths are core depths. Stratigraphic position of the figured interval is shown in Fig. 18.

sandstone bodies occur within each of the three mudstone units. These sandstone-dominated units are proposed here as three new members: the Tyr Member for the sandstones in the Vile Member, the Idun Member for the sandstones in the Ve Member, and the Rind Member for the sandstones in the Bue Member.

Knox \& Holloway (1992) recognised a threefold subdivision of the Lista Formation exclusively based on biostratigraphy. Their L1 and L2 units are separated by the $\mathrm{HO}$ of the dinoflagellate Palaeoperidinium pyrophorum, and the L2 and L3 units are separated by the $\mathrm{HO}$ of Areoligera gippingense. It is noticeable that these two bioevents occur close to the boundaries between the three mudstone members of the Lista Formation proposed herein on the basis of lithology.

Macro- and ichnofossils. Macrofossils have not been reported from the ListaFormation; the formation is moderately to heavily bioturbated (for ichnotaxa, see individual members below).

Microfossils and palynomorphs. The Lista Formation differs from the underlying Våle Formation by lacking common planktonic foraminifers and from the overlying Sele Formation by having an impoverished agglutinated benthic foraminifer assemblage. The Lista Formation contains a characteristic sequence of palynomorph datums that can aid separation of its members. These datums are treated under the individual Lista members below.

Depositional environment. The Lista Formation consists predominantly of hemipelagic mudstones and was probably deposited from very dilute turbidity currents and from suspension.

The composition of the microfaunal assemblage indicates a relatively open marine depositional setting in upper to possibly middle bathyal depths with oxic to dysoxic bottom conditions. This is based on the presence of an impoverished agglutinated foraminifer assemblage dominated by tubular suspension feeders (especially Rhabdammina spp.) together with epifaunal and infaunal detritivores (e.g. Haplophragmoides spp. and Spiroplectammina spectabilis). The relative abundance of tubular suspension feeders is higher in wells in the Siri Canyon than in wells outside the canyon. This probably indicates slightly deeper water within the canyon area during deposition of the Lista Formation.

Age. Selandian-Thanetian (Upper Paleocene). The Selandian-Thanetian boundary may be placed in the middle part of the Lista Formation (in the lower part of the Ve Member, see below), at the $\mathrm{HO}$ of the dinoflagellate Palaeoperidinium pyrophorum.

Correlation. The Lista Formation corresponds to the following succession of upper Paleocene units from onshore 
Fig. 24. Siri-3, type well for the Vile and Kolga Members, and Danish reference well for the Balder Formation. The figure also shows the subdivision of the Sele Formation used by Knox \& Holloway (1992); in this well, the Bue Member is equivalent to the S1a subunit of these authors. Black bar shows cored section.

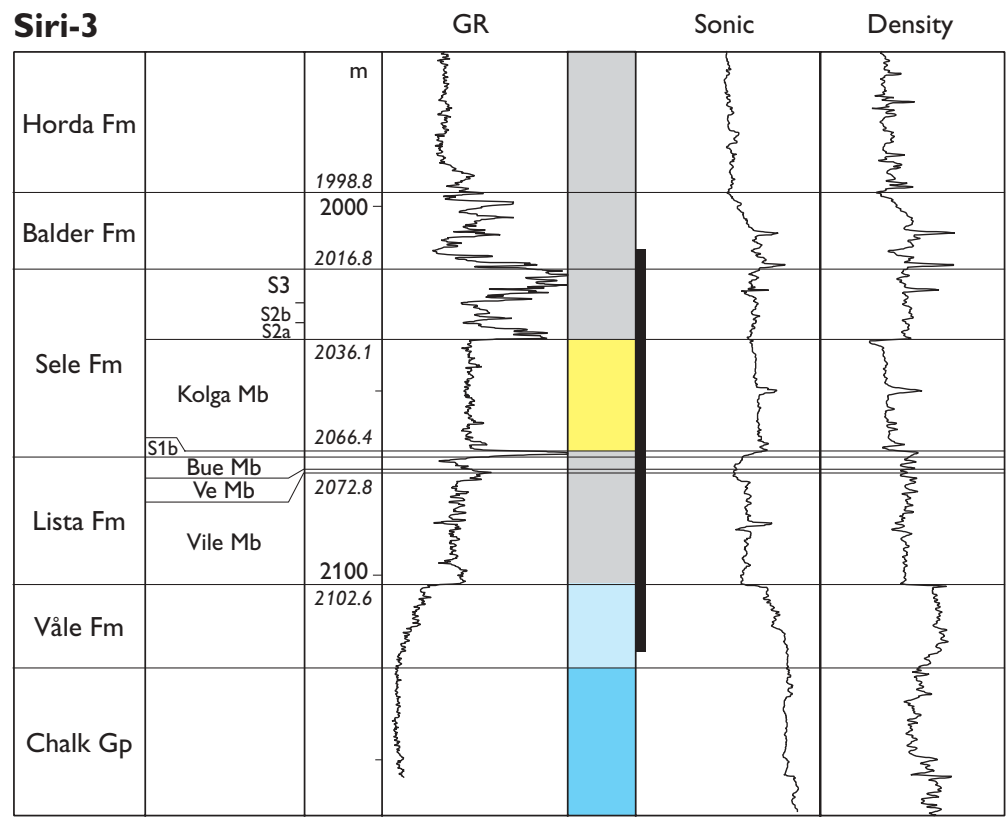

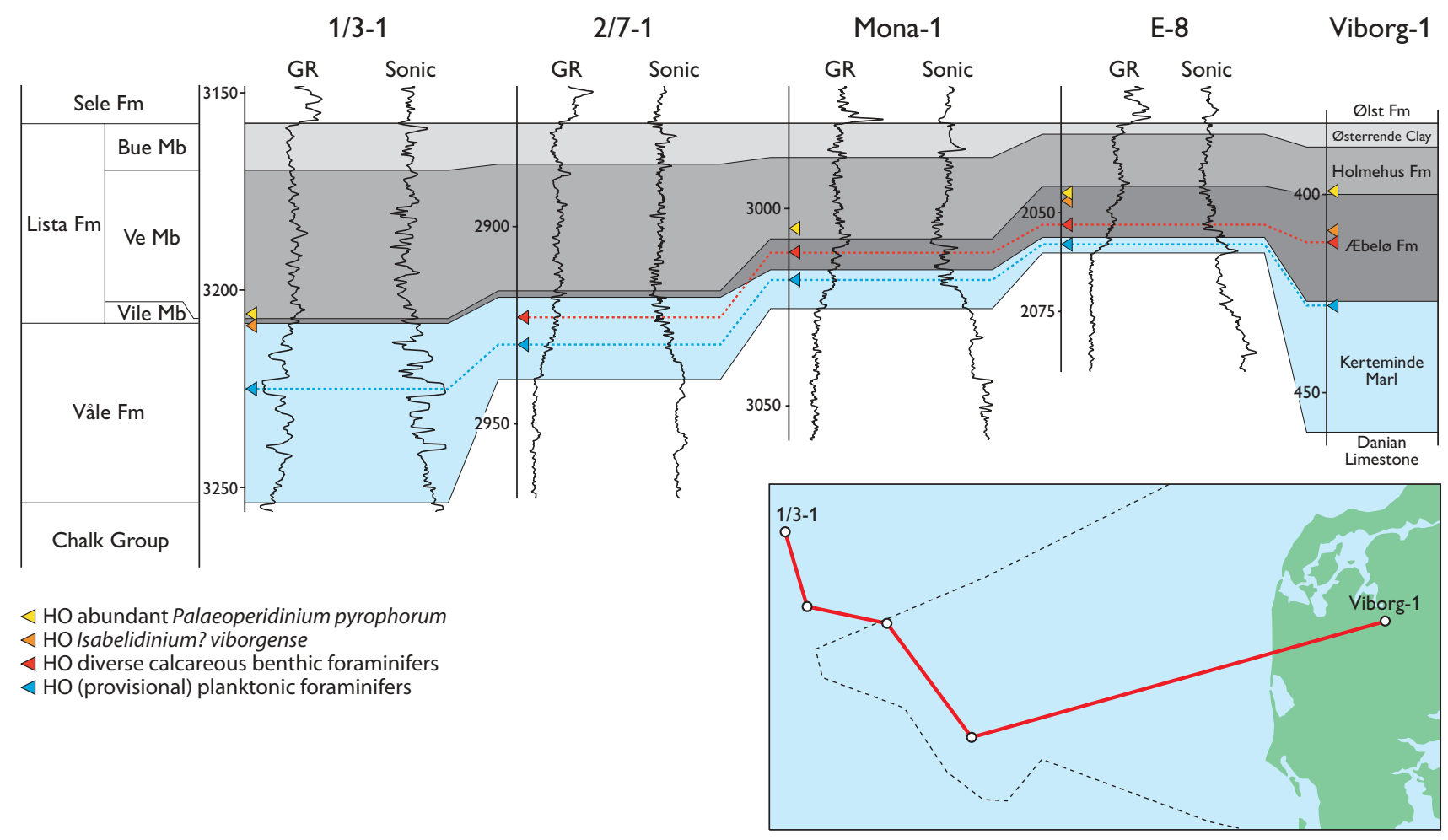

Fig. 25. Correlation diagram showing possible diachronism of the Våle-Vile boundary in an east-west transect extending into the Norwegian sector of the North Sea (1/3-1 and 2/7-1 are Norwegian sector wells). The distribution of biostratigraphic events shows that the Våle-Vile boundary youngs in a westerly direction (HO, highest occurrence). Alternatively, the event distribution could be explained as a result of reworking of older strata into the Lista Formation in the Danish sector. The figure also shows an example of a well (2/7-1) with a relatively large separation between the base of the Sele Formation and the lowest and most conspicuous gamma-ray peak in the formation (see text for further explanation). 


\section{Nini-3}

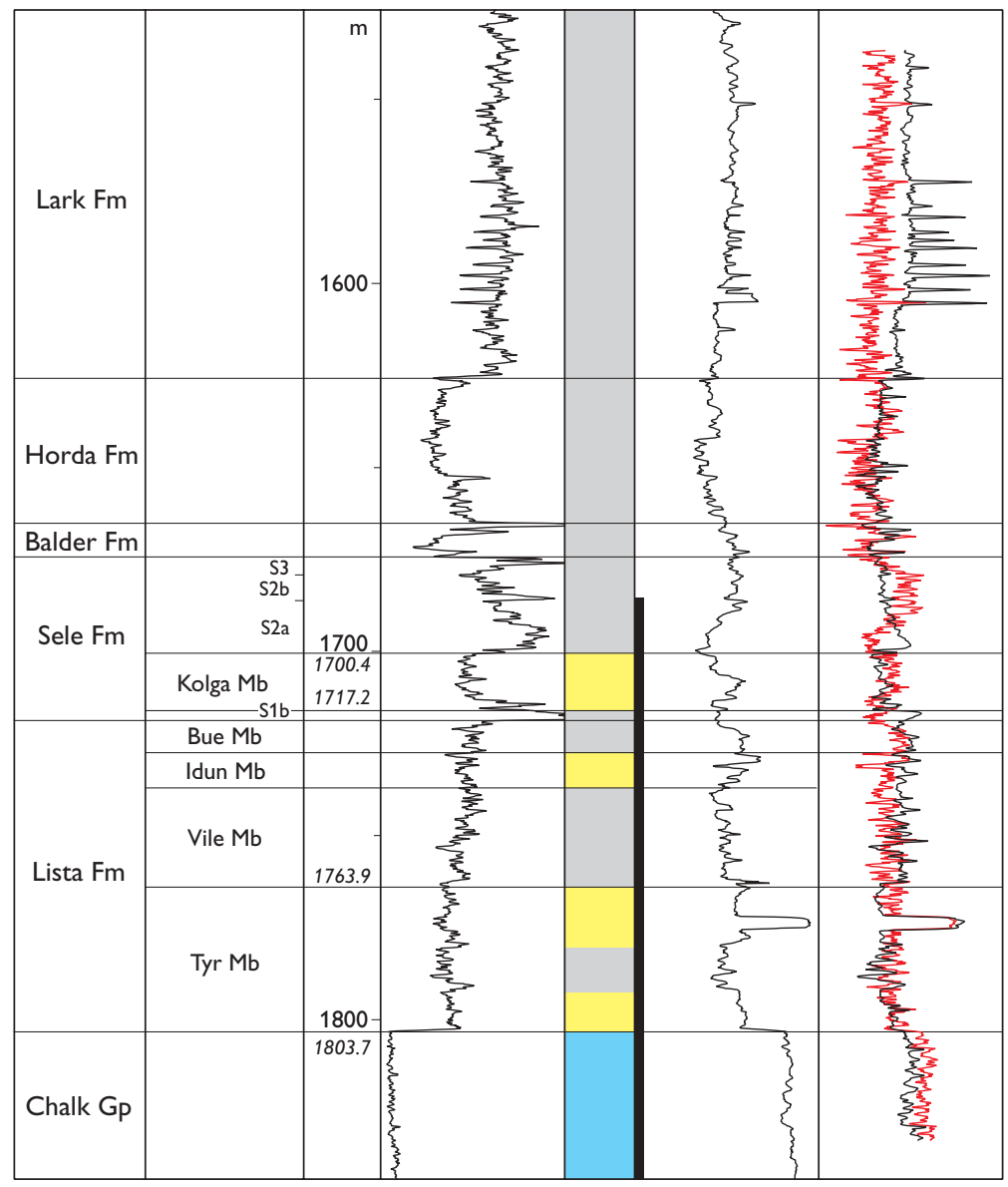

Fig. 26. Nini-3, type well for the Tyr Member and reference well for the Kolga Member. The figure shows the subdivision of the Sele Formation used by Knox \& Holloway (1992); in this well, the Bue Member is equivalent to the $S 1$ a subunit of these authors. Black bar shows cored section.
Denmark: Æbelø Formation (informal mudstone unit described by Bøggild 1918 and Heilmann-Clausen 1995), Holmehus Formation (Heilmann-Clausen et al. 1985) and Østerrende Clay (informal mudstone unit described by Nielsen et al. 1986 and Heilmann-Clausen 1995).

\section{Vile Member}

new member

History. The Vile Member comprises the widespread, dark olive-grey to dark grey, non-calcareous, fissile mudstones that constitute the lower part of the Lista Formation. The unit was recognised by a stratigraphic working group at Statoil Norway in the mid-1990s and informally named the 'Vile Formation'.

Derivation of name. After Vile, the brother of Odin.

Type well. Danish sector well Siri-3, 2102.6-2072.8 m MBRT (Fig. 24; Plate 4).
Reference wells. Danish sector wells E-8, 2057.0-2044.0 m MDKB (Fig. 13); Cleo-1, 2812.0-2792.4 m MDKB (Fig. 21; Plate 1).

Distribution and thickness. The Vile Member has been recognised in a large number of North Sea wells, and the unit probably has a basinwide distribution. However, it is apparently lacking in the Siri Canyon wells Connie-1 and Siri-2 (Figs 29, 31), probably due to erosion. Its thickness varies between 0 and $30 \mathrm{~m}$ over most of the Danish sector. It greatest thickness is reached in the Siri Canyon.

Lithology. The member consists of dark olive-grey to dark grey, non-calcareous, swelling, smectitic, fissile mudstones (Fig. 23). Thin silicified layers occur in the member. Calcite is common and occurs as small nodules and larger concretions.

In the Siri Canyon, small pyrite concretions and less than $1 \mathrm{~cm}$ thick, silty, very fine-grained glaucony-rich sand- or siltstone laminae are locally present in the Vile Member. The laminae are parallel to the bedding of the mudstones; they have sharp bases and are normally grad- 
Fig. 27. Core log of the Tyr Member in the Nini-3 well. For legend, see Fig. 9.

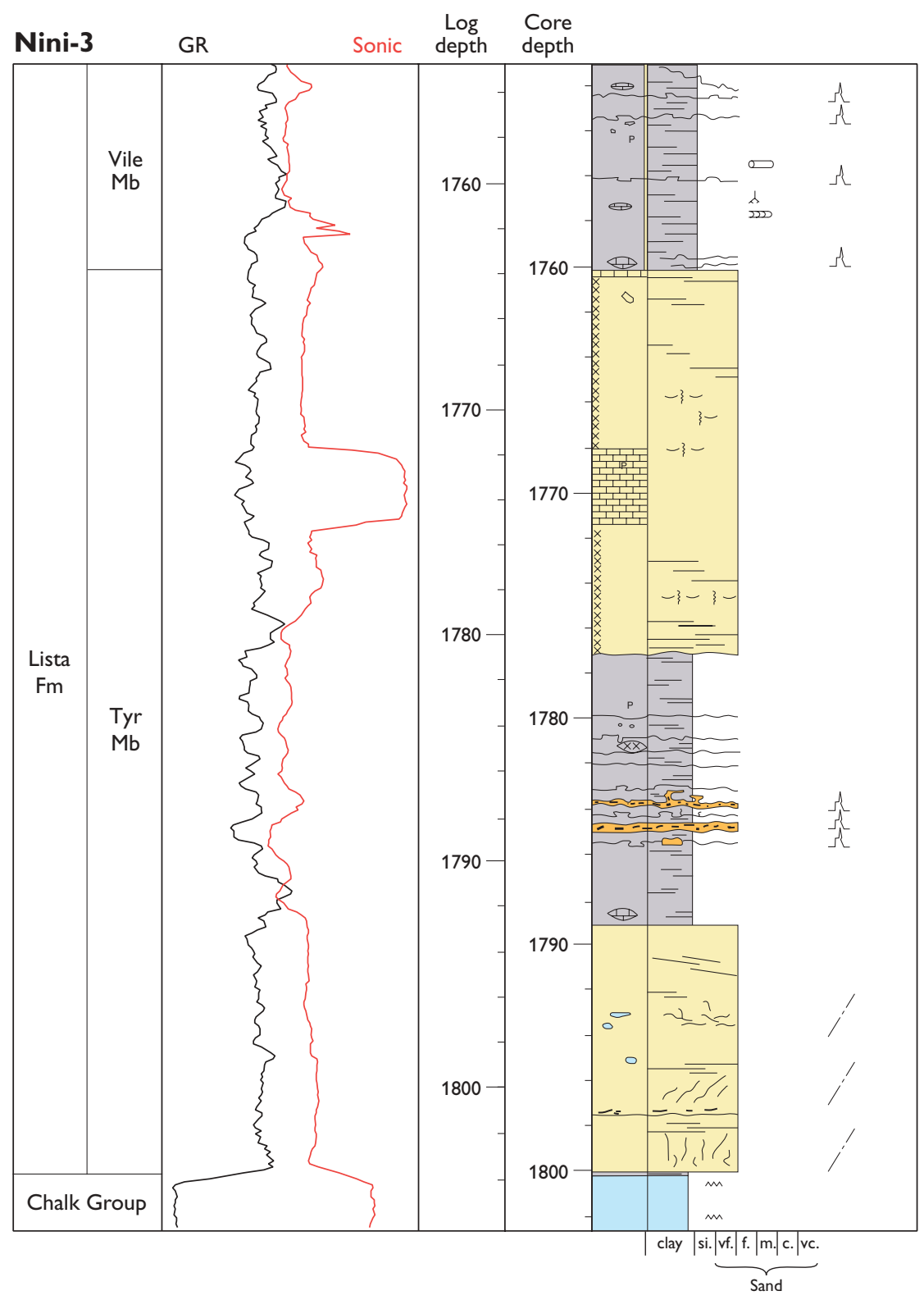

ed. Thin concordant or discordant, postdepositional sandstone intrusions are locally present. In the lower part of the Vile Member, the intrusions are only a few millimetres thick, but they often increase in number and thickness towards the top of the member (Fig. 11).

Log characteristics. In most wells there is a gradual increase in gamma-ray response up through the Vile Member, accompanied by a slight decrease in sonic readings.

Boundaries. The lower boundary of the Vile Member is that of the Lista Formation. The upper boundary is defined by the base of the Ve Member; boundaries with the sandstone-dominated Tyr Member are described under that member.
Macro- and ichnofossils. The Vile Member is moderately to intensely bioturbated. Ichnogenera in the member include Chondrites ispp., Phycosiphon ispp., Planolites ispp. and Zoophycos ispp.

Microfossils and palynomorphs. The Vile Member is characterised by a general decrease in the diversity of benthic foraminifers and radiolaria from its base to its top. In the Danish sector, the transition from the underlying Våle Formation to the Vile Member is marked by the provisional $\mathrm{HO}$ of planktonic foraminifers. A conspicuous drop in diversity of benthic foraminifers takes place in the middle of the Vile Member. The HO of the dinoflagellate Isabelidinium? viborgense is an important intra-Vile marker located in the upper part of the member. Above it, a sudden decrease in the abundance of radiolaria further char- 


\section{Augusta-1}

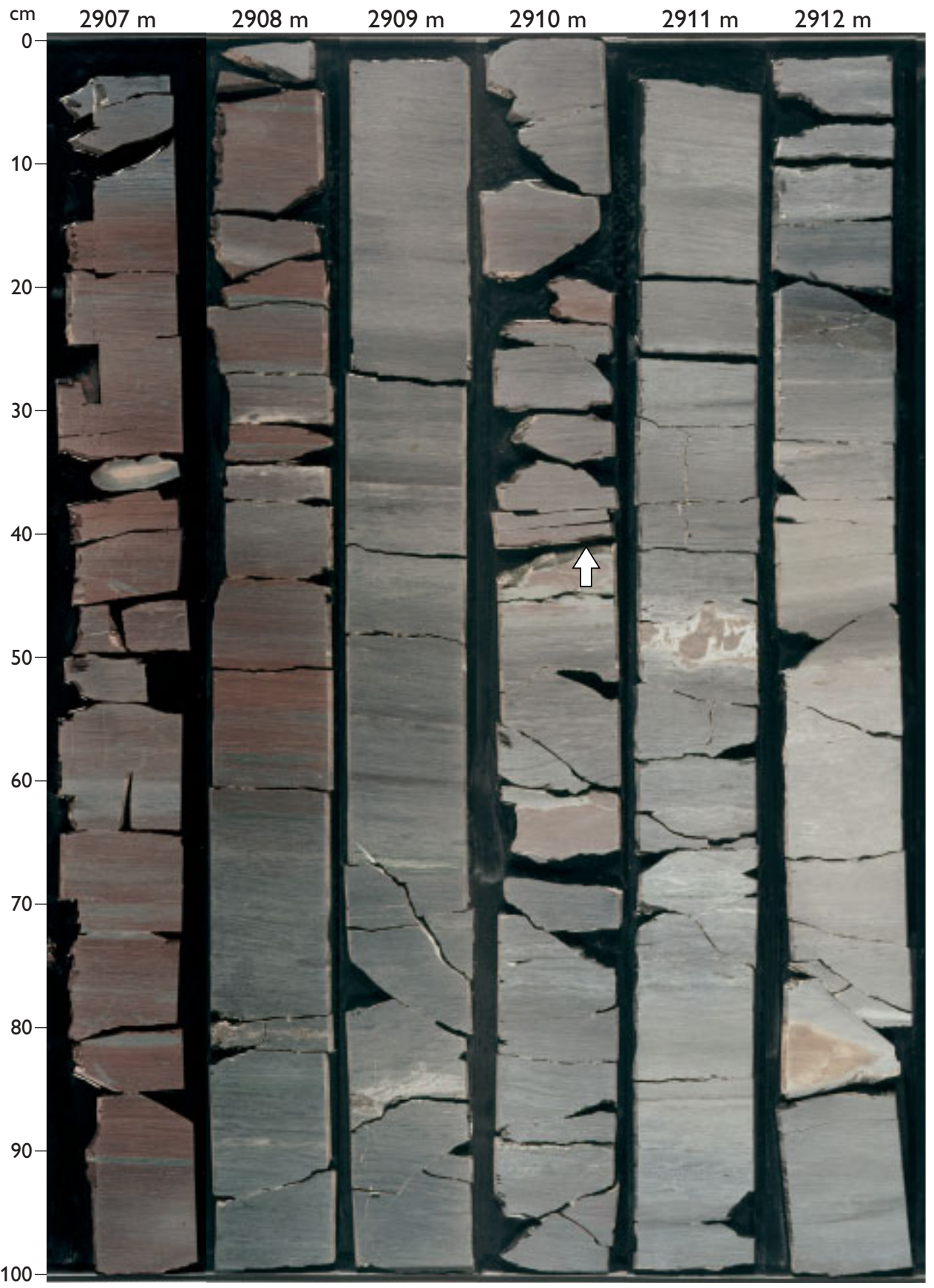

Fig. 28. Core photographs of mudstones of the Vile and Ve Members in the Augusta-1 well. Depths are core depths. The boundary between the two members is placed where greenish and reddish grey mudstones become dominant, at $2910.4 \mathrm{~m}$ (arrow). This depth corresponds to log depth $2913.3 \mathrm{~m}$ on Fig. 17. acterises a level within the uppermost part of the Vile Member. The transition from the Vile Member to the overlying Ve Member is marked by a conspicuous drop in the abundance of the dinoflagellate Palaeoperidinium pyrophorum (which has its $\mathrm{HO}$ at a slightly higher stratigraphic level, within the lower part of the Ve Member, see below).

Depositional environment. The mudstones of the Vile Member are hemipelagic deposits, whereas the thin sandstone and siltstone laminae are interpreted as the deposits of low-density turbidity currents. The presence of Zoophycos ispp. suggests depositional water depths of at least 200 m (Bottjer \& Droser 1992).

Age. Selandian.

Correlation. The Vile Member corresponds to the Æbelø Formation, onshore Denmark (informal mudstone unit described by Bøggild 1918 and Heilmann-Clausen 1995). It corresponds to the Lista L1 subunit of Knox \& Holloway (1992). 
Biostratigraphic correlation with well sections in the Norwegian North Sea sector may indicate that the lower boundary of the Vile Member is diachronous (Fig. 25). In the type well for the Lista Formation (Norwegian well 2/7-1; Fig. 25), its base (i.e. its contact with the marlstones of the underlying Våle Formation) is above the $\mathrm{HO}$ of a diverse calcareous benthic foraminifer assemblage. In wells in the Danish sector, this event occurs within the Vile Member. Similarly, the provisional HO of planktonic foraminifers, an event that is close to the boundary between the Våle and Lista Formations in Denmark, is found well within the Våle Formation in well 2/7-1. In the type well for the Våle Formation (Norwegian well 1/3-1; Fig. 25), the $\mathrm{HO}$ of I.? viborgense coincides with the Vale-Lista boundary (I. Prince, unpublished biostratigraphic data). This event occurs above the Våle Formation in the Danish sector, in the middle to upper part of the Vile Member. In the Danish onshore well Viborg-1, the latter event and the $\mathrm{HO}$ of the diverse calcareous benthic foraminifer assemblage occur above the Kerteminde Marl in the upper part of the Æbelø Formation, a correlative of the Vile Member (Fig. 25; Heilmann-Clausen 1985). The distribution pattern of the biostratigraphic events indicates that sedimentation of marls continued in the Norwegian sector some time after marl sedimentation was replaced by sedimentation of non-calcareous mudstones in the Danish sector. Alternatively, calcareous foraminifer assemblages and associated lithologies have been reworked into higher levels of the Våle Formation or even into the Lista Formation in the Danish sector.

\section{Tyr Member}

new member

History. The Tyr Member consists of glaucony-rich, sandstone-dominated deposits that are laterally equivalent to, and commonly underlain and overlain by, mudstones of the Vile Member. These sandstones were previously recognised by a stratigraphic working group at Statoil Norway in the mid-1990s and informally referred to the Ty Formation of Hardt et al. (1989).

Derivation of name. After Tyr, the son of Odin.

Type well. Danish sector well Nini-3, 1803.7-1763.9 m MDRT (Figs 26, 27; Plate 4).

Reference well. Danish sector well Cecilie-1, 2276.6-2241.7 m MDRT (Figs 8, 19).
Distribution and thickness. The Tyr Member has only been encountered in the Siri Canyon and it may be restricted to that area. It reaches a thickness of up to $40 \mathrm{~m}$ (Fig. 20a).

Lithology. The Tyr Member is characterised by thick beds of olive-green to greenish grey, very fine-grained to finegrained and well-sorted sandstone (Fig. 27). Rounded and translucent quartz grains dominate, but the content of glaucony grains is high (15-20\%), hence the greenish colour of the sandstones. Mica and small pyrite concretions are present in small amounts throughout the member. Angular chalk and claystone clasts occur locally in the sandstones. The sandstones are partly calcite-cemented. Intrusive sandstones are common, particularly towards the top of the member where they may be several metres thick (Fig. 8). Subordinate interbedded dark grey noncalcareous mudstones resemble those of the laterally equivalent Vile Member.

Log characteristics. The Tyr Member is best identified on the density log where the sandstones are characterised by a conspicuously lower density than the associated mudstones. The sandstones may also be identified from a combination of the density and neutron logs, as the presence of pure sandstone results in a 'cross-over' of the two $\log$ curves (Figs 19, 26). The gamma-ray response resembles that of the underlying Våle Formation, but is slightly lower than the response of the Vile Member (Figs 8, 26). This $\log$ pattern makes it feasible to differentiate even minor sand units from mudstone beds in the Tyr Member. Thicker sand units may show decreasing- or increasingupwards gamma-ray values. These trends do not seem to be related to grain-size variations, judging from core studies.

Boundaries. The boundaries to the mudstones of the Vile Member, the marlstones of the Vale Formation and the chalks of the Ekofisk Formation are sharp and characterised by prominent shifts in gamma, sonic and density log readings (Figs 19, 26, 27). In some wells, the Tyr Member overlies the Våle Formation or the Ekofisk Formation with an erosional contact (e.g. Nini-3; Figs 26, 27).

Depositional environment. Although the sandstones of the Tyr Member were deposited from highly concentrated gravity flows, their present appearance is dominated by the effects of postdepositional liquefaction and fluidisation.

Age. Selandian.

Correlation. The Tyr Member is contemporaneous with parts of the lithologically dissimilar Æbelø Formation in 
onshore Denmark and with the lower part of the Heimdal Formation of Deegan \& Scull (1977) as well as the Andrew Sandstone and the Mey Sandstone Member of Knox \& Holloway (1992) in the Norwegian and UK sectors of the southern Viking Graben. However, it is not contiguous with the latter three sandstone units and has a different source area.

\section{Ve Member}

new member

History. The Ve Member consists of variegated mudstones that have previously been recognised from North Sea wells as the Holmehus Formation by Heilmann-Clausen et al. (1985), who gave no further details, and by Danielsen \& Thomsen (1997), who indicated its presence in several wells. The unit was also recognised by a stratigraphic working group at Statoil Norway in the mid-1990s and informally named the 'Ve Formation'.

Derivation of name. After Ve, the brother of Odin.

Type well. Danish sector well Augusta-1, 2913.3-2903.0 m MDRT (Fig. 17).

Reference wells. Danish sector wells E-8, 2044.0-2030.3 m MDKB (Fig. 13); Cleo-1, 2792.4-2777.6 m MDKB (Fig. 21; Plate 1).

Distribution and thickness. The sediments of the Ve Member have been recognised from a large number of North Sea wells, and the unit probably has an almost basinwide distribution. Its thickness varies from 0 to $21 \mathrm{~m}$ in the Danish sector.

Lithology. The Ve Member consists of mottled green, bluish green, reddish brown and brown mudstones (Fig. 28). Mottled, purple coloured intervals are also present locally. The middle part of the member is often characterised by a thick dark reddish brown to chocolate brown interval. The Ve Member mudstones are non-calcareous and rich in smectite. Pyrite and carbonate concretions occur throughout the member. A weak biogenic lamination is sometimes observed in cores. Only very little organic material is present in the member. In the Siri Canyon, thin intrusive sandstones are common in the Ve Member.

Log characteristics. In general, the gamma-ray log shows a decreasing-upwards trend through the Ve Member, as opposed to the increasing trend through the underlying
Vile Member. In the uppermost part of the Ve Member, the gamma-ray response increases over a short interval before reaching the base of the overlying Bue Member. The sonic log pattern throughout the Ve Member is smooth and relatively stable compared with the sonic pattern of the Vile Member. It also differs from the latter in having an increasing-upwards trend. The log pattern of the Ve Member differs from that of the overlying Bue Member in having a lower gamma-ray response level.

Boundaries. The lower boundary, with the Vile Member, is placed at the first appearance of greenish, bluish or reddish brown mudstones above the dark olive-grey to dark grey mudstones of the Vile Member. The colour change from Vile to Ve mudstones is often gradational and the boundary may be difficult to define precisely (Fig. 28), especially when only cuttings samples are available. However, in the colour transition interval, a gamma-ray spike separates an interval with an increasing-upwards gammaray trend below from an interval with a decreasing gamma-ray trend above (compare Figs 17 and 28). In the absence of a clear indication of the boundary level from sediment colour change, the gamma spike at the shift from increasing to decreasing gamma-ray values may be used as a marker for the boundary. The Vile Member is absent from the Connie-1 well, and in this well the lower contact of the Ve Member is with the marlstones of the Vale Formation (Fig. 31). The upper boundary is at the base of the Bue Member (see below). Boundaries with the Idun Member are described under that member.

Macro- and ichnofossils. The mudstones of the Ve Member are normally heavily bioturbated. The most common trace fossils are Phycosiphon ispp. and Zoophycos ispp. Chondrites ispp. and Planolites ispp. are present, but rare.

Microfossils and palynomorphs. In the Danish sector of the North Sea, the HO of abundant Palaeoperidinium pyrophorum is located at or close to the Vile-Ve boundary. The HOs of P. pyrophorum and Palaeocystodinium australinum are in the lower part of the Ve Member. In general, the dinoflagellate assemblage from the upper part of the Ve Member is sparse and is characterised by specimens of Areoligera gippingensis. An acme of the latter species marks a level in the upper part of the Ve Member. The highest in situ occurrence of the dinoflagellate Alisocysta margarita is located close to the top of the Ve Member.

Depositional environment. Deposition of the mudstones of the Ve Member was controlled by hemipelagic sedimentation and sedimentation from dilute turbidites. The 
Fig. 29. Connie-1, type well for the Idun and Rind Members. In this well, the Rind Member may be divided into three major sandstone intervals. The Idun Member consists of two thick sandstone intervals, separated by a thick mudstone unit. Black bars show cored sections.

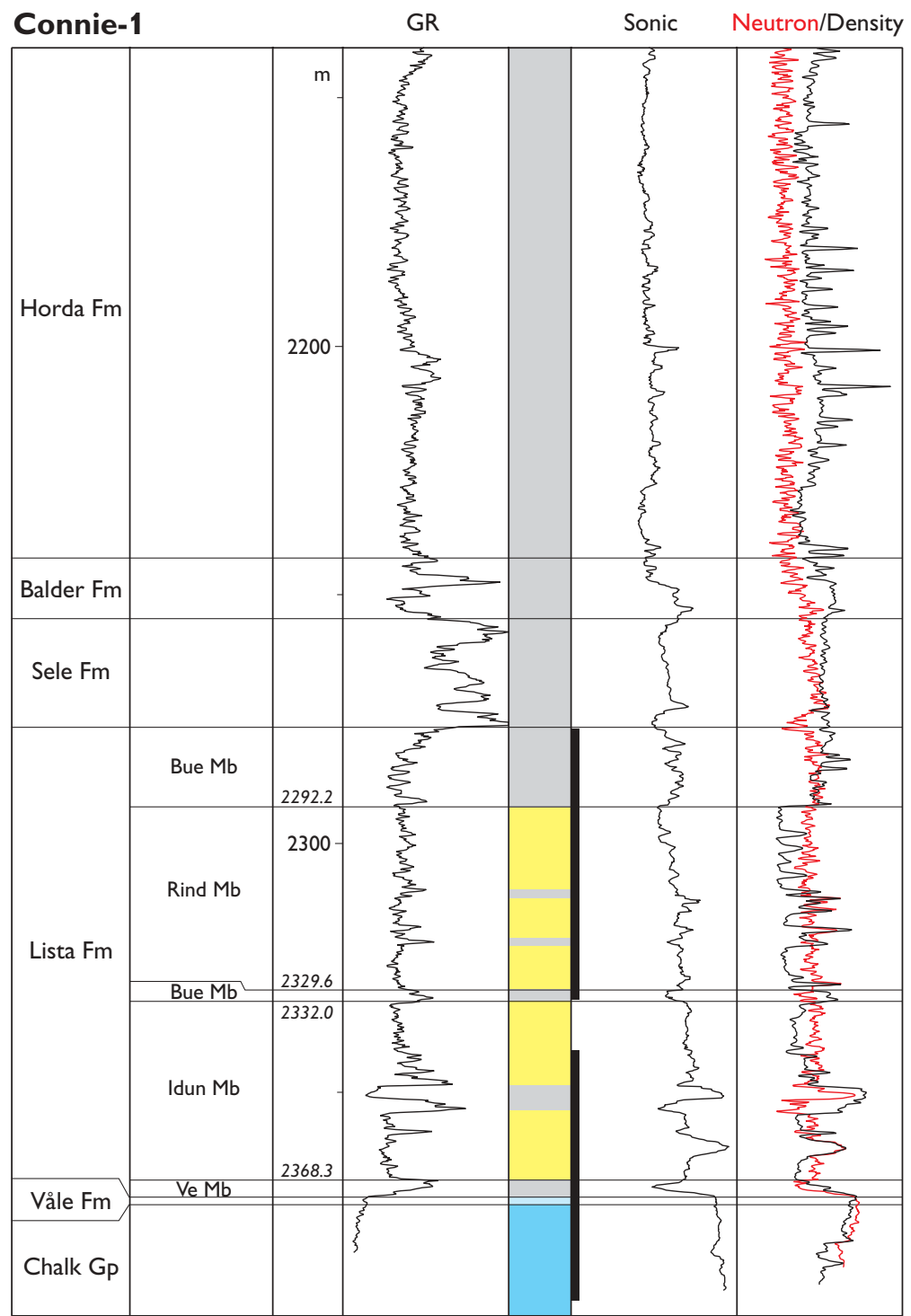

occurrence of the trace fossil Zoophycos ispp. indicates a water depth of at least 200 m (Bottjer \& Droser 1992). The overall high degree of bioturbation, the lack of organic material and the greenish, bluish and reddish brown colours together suggest oxygenated bottom conditions.

Age. Selandian-Thanetian. The Selandian-Thanetian boundary is placed at the $\mathrm{HO}$ of the dinoflagellate Palaeoperidinium pyrophorum, in the lower part of the Ve Member.

Correlation. The Ve Member correlates with the Holmehus Formation (Heilmann-Clausen et al. 1985) onshore Denmark and is lithologically indistinguishable from that formation.

\section{Idun Member}

new member

History. The Idun Member consists of sandstone-dominated deposits that are laterally equivalent to, and commonly underlain by, mudstones of the Ve Member. This sandstone unit was previously recognised by a stratigraphic working group at Statoil Norway in the mid-1990s and was informally referred to the Heimdal Formation of Deegan \& Scull (1977).

Derivation of name. After Idun, the goddess of youth.

Type well. Danish sector well Connie-1, 2368.3-2332.0 m MDRT (Figs 29, 30). 


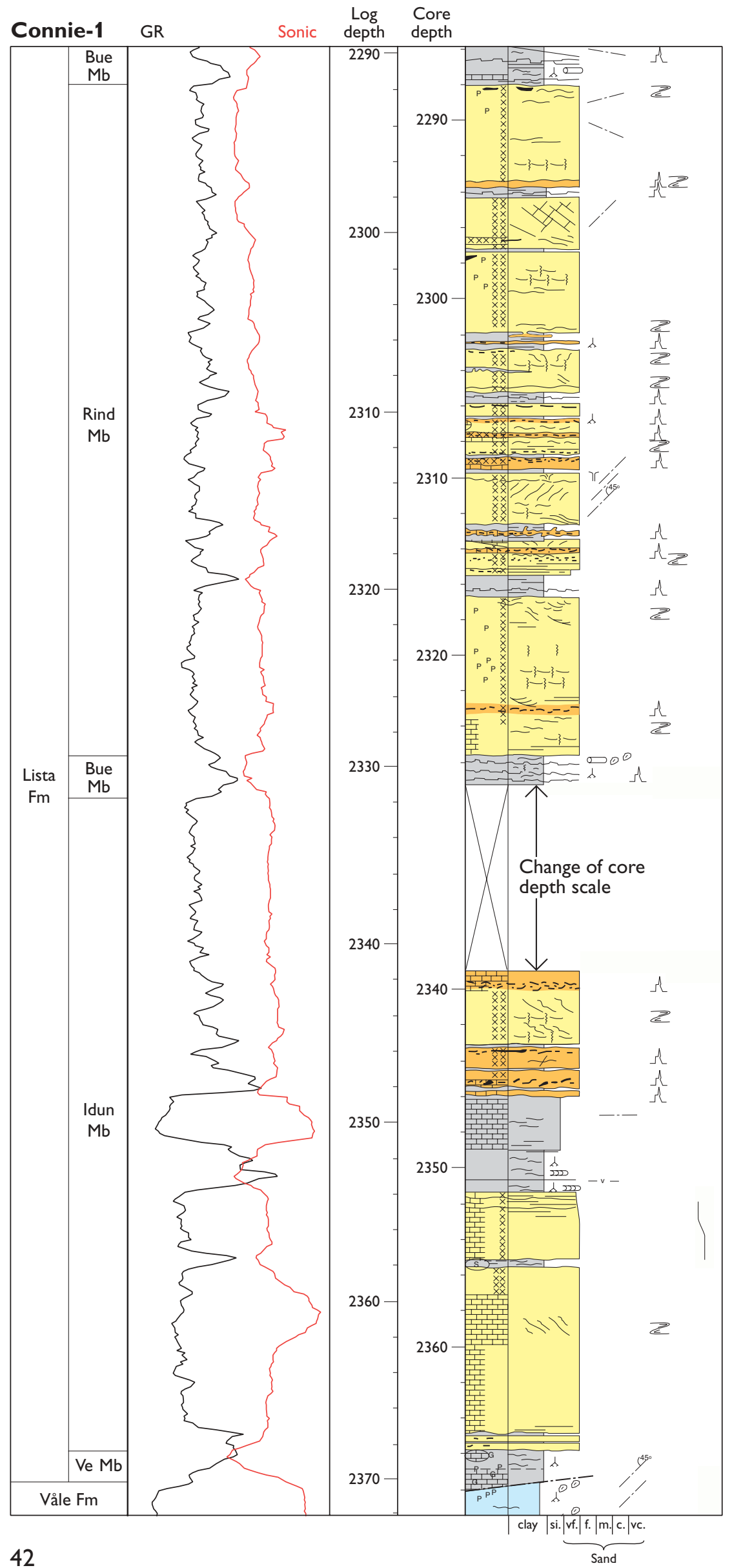

Fig. 30. Core log of the Idun and Rind Members in the Connie-1 well. For legend, see Fig. 9. Minor mudstone beds separate the three major sandstone intervals of the Rind Member. Minor mudstone layers are also intercalated with the Idun Member sandstone intervals. The core depth scale of the lower core is offset by $c .1 .6 \mathrm{~m}$ relative to the scale of the upper core in the figure. For reasons of consistency with core data from this well, the original (albeit erroneous) core depths of the lower core are maintained in the figure. This does not affect the depths of the top and base of the Idun Member given in the text, as these are based on log depths. 
Fig. 31. Siri-2, reference well for the Idun Member. Black bar shows cored section.

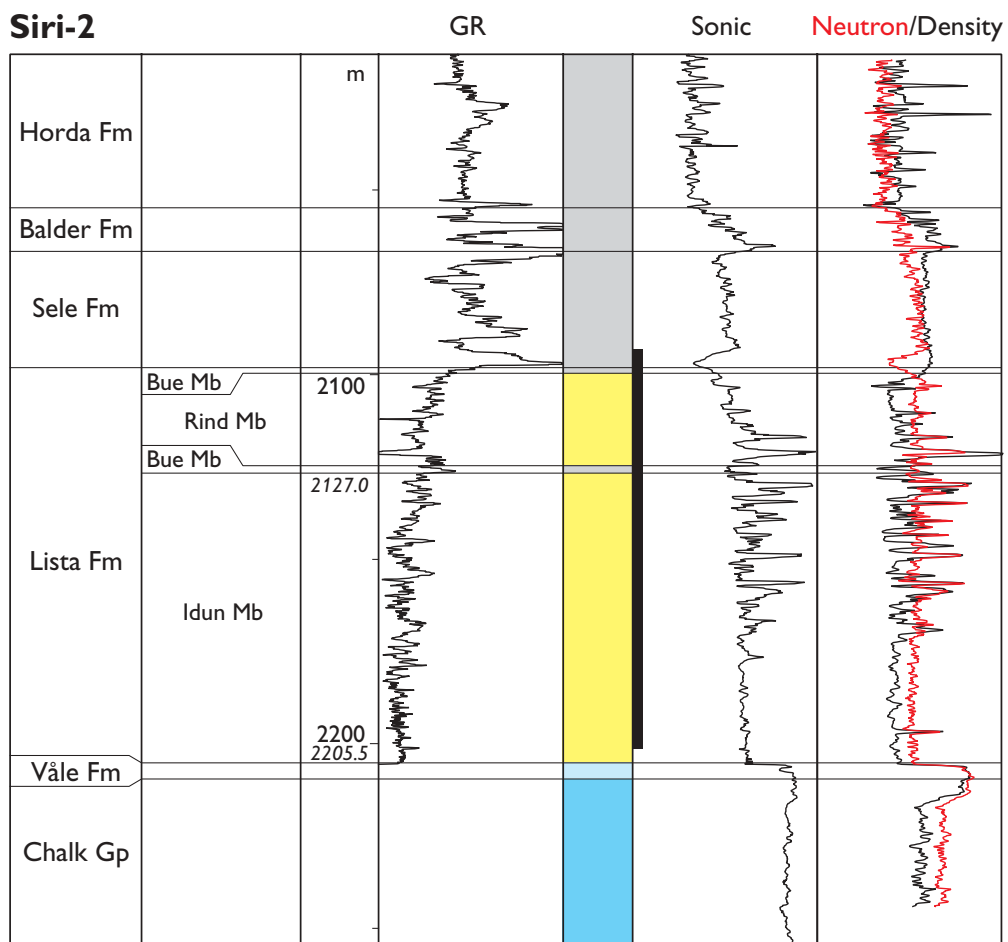

Reference well. Danish sector well Siri-2, 2205.5-2127.0 m MDRT (Fig. 31).

Distribution and thickness. The Idun Member is only known from the Siri Canyon, and it may be restricted to that area (Fig. 20b). It reaches a thickness of up to $179 \mathrm{~m}$ in the Siri-2 well.

Lithology. The Idun Member is dominated by very finegrained to fine-grained, well-sorted sandstones (Fig. 30). Rounded and translucent quartz grains dominate, but the content of glaucony grains is high (15-25\%). The sandstones are olive green to greenish grey due to the high content of glaucony. Mica and small pyrite concretions are present in small amounts. Angular chalk and claystone clasts occur locally. Intrusive sandstones are also represented (Figs 11, 12, 30). The sandstones and adjacent mudstones are partly calcite-cemented. In the Nini and Siri wells, the sandstones occur in thick amalgamated successions with only rare, thin mudstone interbeds; the latter are lithologically comparable to the laterally equivalent Ve Member mudstones (see above). In the Connie-1 well, however, the sand-rich succession is interrupted by a discrete $6 \mathrm{~m}$ thick mudstone unit (Fig. 30).

Log characteristics. The sandstone-dominated Idun Member is best identified on the density log where it is characterised by a conspicuously lower density than the under- lying and overlying mudstones (Figs 29, 31). The sandstone component may also be identified from a combination of the density and neutron logs, as the presence of pure sandstones results in a 'cross-over' of the two log curves (Figs 29, 31). The Idun Member is characterised by a blocky, decreasing-upwards gamma-ray and density $\log$ pattern. Intervals with an overall constant gamma-ray pattern may be characterised by many small-scale increasing- or decreasing-upwards gamma-ray cycles.

Boundaries. In sections where the sandstones of the Idun Member are enveloped by mudstones of the Ve Member, the boundaries are sharp and characterised by prominent shifts on the gamma-ray, sonic and density logs (Figs 29, 30). Where the Ve Member is absent, comparable, sharp boundaries are observed with the mudstones of the Vile Member beneath and the Bue Member above (Figs 11, 26, 30). In the Siri-2 well, the lower Lista Formation is absent and an erosive unconformity separates the Idun Member sandstones from the marlstones of the Våle Formation (Fig. 31).

Depositional environment. Although the sandstones of the Idun Member were deposited from highly concentrated gravity flows, their present appearance largely records postdepositional liquefaction and fluidisation processes.

Age. Selandian-Thanetian. 


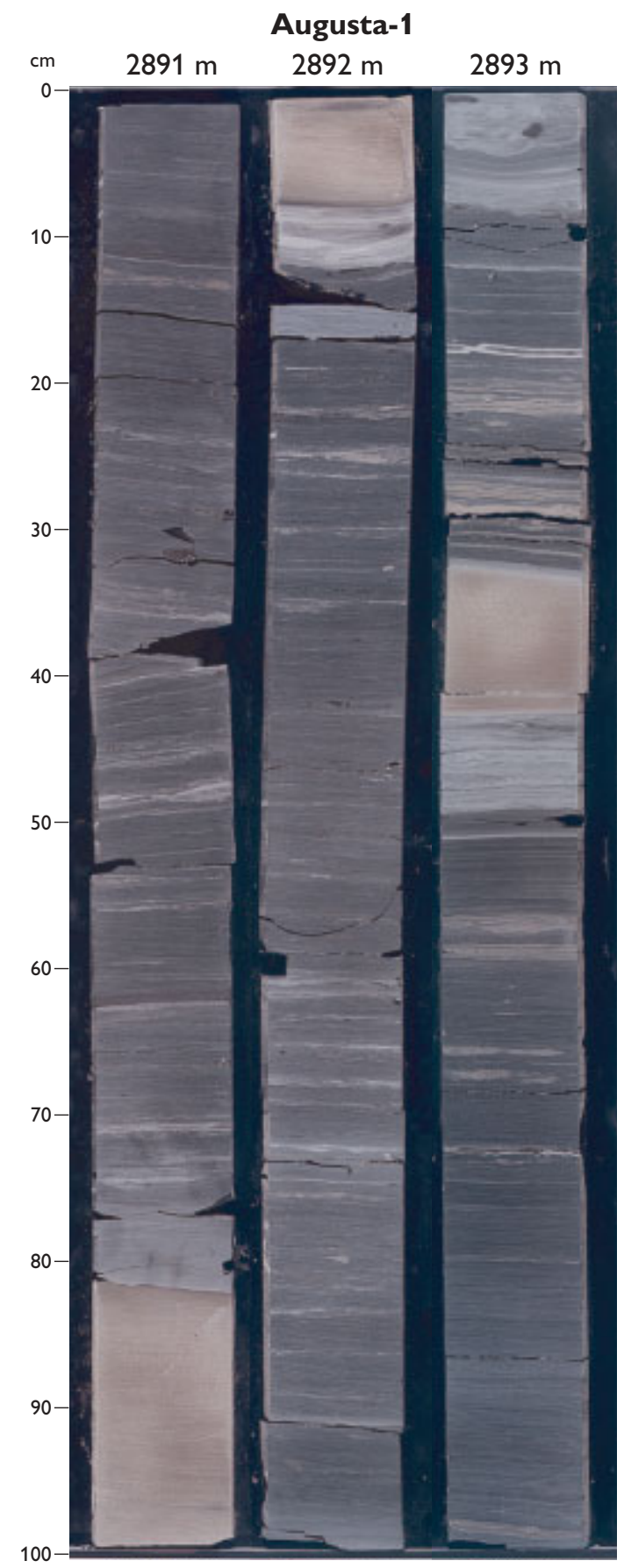

Fig. 32. Core photographs showing the Bue Member mudstones with numerous sandstone laminae in the Augusta- 1 well. Depths are core depths.

Correlation. The Idun Member is contemporaneous with parts of the lithologically dissimilar Holmehus Formation onshore Denmark and with parts of the Heimdal Formation of Hardt et al. (1989) and the Lower Balmoral Sandstone and Tuffite of the Mey Sandstone Member of Knox \& Holloway (1992). The Idun Member is not contiguous with these sandstone units, however, and has a different source area.

\section{Bue Member \\ new member}

History. The Bue Member encompasses the light to dark grey and greyish black mudstones that occur between the top of the Ve Member and the base of the Sele Formation. These mudstones have not previously been recognised as a separate unit in the Danish sector.

Derivation of name. After Bue, the son of Odin and Rind.

Type well. Danish sector well Augusta-1,2903.0-2894.4m MDRT (Fig. 17).

Referencewells. Danish sector wells E-8, 2030.3-2027.6 m below MDKB (Fig. 13); Cleo-1, 2777.6-2765.5 m MDKB (Fig. 21; Plate 1).

Distribution and thickness. The sediments of the Bue Member have been recognised from a large number of North Sea wells, and the unit probably has a basinwide distribution. Its thickness varies from 0 to $18 \mathrm{~m}$ in the Danish sector.

Lithology. The Bue Member consists of light to dark grey and greyish black mudstones. The mudstones are generally rich in smectite. In the Siri Canyon, the upper part of the member sometimes contains laminae of very finegrained to fine-grained sandstones or siltstones, mimicking the laminated mudstones of the overlying Sele Formation (Figs 32, 39). The laminae are less than $2 \mathrm{~cm}$ thick, have sharp bases, are normally graded and show parallel lamination. Concordant or discordant sandstone intrusions are locally present in the member (Fig. 8). Small calcite and siderite concretions are occasionally present. Moderately to intensely bioturbated intervals are interbedded with non-bioturbated intervals. Tuff layers may be present in the member.

Log characteristics. The gamma-ray response of the Bue Member is generally higher than that of the underlying Ve Member, but lower than that of the overlying Sele Formation. In some Siri Canyon wells, minor coarseningupwards cycles are indicated by the gamma-ray log of the Bue Member.

Boundaries. The transition from typical lithologies of the Ve Member to those of the Bue Member is often grada- 
tional and the boundary may therefore be difficult to position precisely. It is placed where mottled green, bluish green, reddish brown and brown mudstones pass upwards into grey mudstones with sandstone and siltstone laminae. On the petrophysical logs, this transition is reflected by a shift from decreasing- to increasing-upwards gamma-ray values or at an abrupt increase in the gamma-ray response. The upper boundary of the Bue Member is at the base of the Sele Formation.

Macro- and ichnofossils. Trace fossils recognised in the Bue Member are Phycosiphon ispp., Planolites ispp., Thalassinoides ispp. and rare Zoophycos ispp.

Microfossils and palynomorphs. The Ve-Bue boundary is bracketed by the stratigraphic succession of the $\mathrm{HO}$ of in situ Alisocysta margarita (occurring in the upper Ve Member) followed by the $\mathrm{HO}$ of an impoverished assemblage of benthic agglutinated foraminifers (in the lower part of the Bue Member). The upper part of the Bue Member is characterised by common spores and pollen, in particular bisaccate pollen and Inaperturopollenites spp. The BueSele boundary is marked by the base of an acme of the dinoflagellate genus Apectodinium and the LO of Apectodinium augustum.

Depositional environment. The normally graded sandstone to siltstone laminae in the upper part of the member indicate that deposition of the Bue Member took place from dilute, low-density, turbidity currents in a generally sediment-starved environment at this level. The minor coarsening-upwards cycles observed on petrophysical logs from some Siri Canyon wells probably indicate either small distal lobes of deep-water channel-sandstones or levee deposits.

Age. Thanetian.

Correlation. The Bue Member corresponds to the Østerrende Clay (informal mudstone unit described by Nielsen et al. 1986 and Heilmann-Clausen 1995) onshore Denmark. The level here defined as the boundary between the Ve and the Bue Members was correlated by Knox (1997 fig. 3; the Lista-Sele boundary of this worker) with the boundary between the Holmehus Formation and the Østerrende Clay (as 'Grey Clay') onshore Denmark. The Bue Member further correlates with the lower part of the S1a subunit of the Sele Formation established by Knox \& Holloway (1992; see correlation section under the Lista Formation for further details).
Rind Member

new member

History. The Rind Member consists of sandstone-dominated deposits that are laterally equivalent to, and commonly underlain and overlain by, mudstones of the Bue Member. Sandstone bodies at this stratigraphic level were previously recognised by a stratigraphic working group at Statoil Norway in the mid-1990s and were informally referred to the Heimdal Formation of Deegan \& Scull (1977).

Derivation of name. After the giantess Rind.

Type well. Danish sector well Connie-1, 2329.6-2292.2 m MDRT (Figs 29, 30).

Reference well. Danish sector well Sandra-1, 2066.32004.8 m MDRT (Fig. 33).

Distribution and thickness. The Rind Member has only been encountered in the Siri Canyon, and it may be restricted to that area where it reaches a thickness of $62 \mathrm{~m}$ (Fig. 20c).

Lithology. The Rind Member consists of very fine-grained, well-sorted sandstones interbedded with thin mudstone beds that typically form less than $15 \%$ of the member (Fig. 30). Rounded and translucent quartz grains dominate in the sandstones, but the content of glaucony grains in the very fine-grained to fine-grained size fraction is high $(15-25 \%)$. The sandstones are olive green to greenish grey due to the high content of glaucony. Mica and small pyrite concretions are present in small amounts. Angular chalk and claystone clasts occur locally in the sandstones, which are partly calcite-cemented. The interbedded mudstones are lithologically comparable to the Bue Member mudstones (see above).

Log characteristics. The Rind Member is best recognised on the density log where it shows either a blocky or a serrate pattern created by the alternation of sandstone beds or amalgamated units (low density) with thin mudstone beds (high density; Figs 29, 33). The sandstones may also be identified from a combination of the density and neutron logs, since the presence of pure sandstones results in a 'cross-over' of the two log curves (Figs 29, 33). The gamma-ray log shows a low-amplitude serrate pattern. This pattern does not reflect alternating sand or mudstones, judging from core inspection.

Boundaries. The boundary between the sandstones of the Rind Member and the mudstones of the Bue Member is 


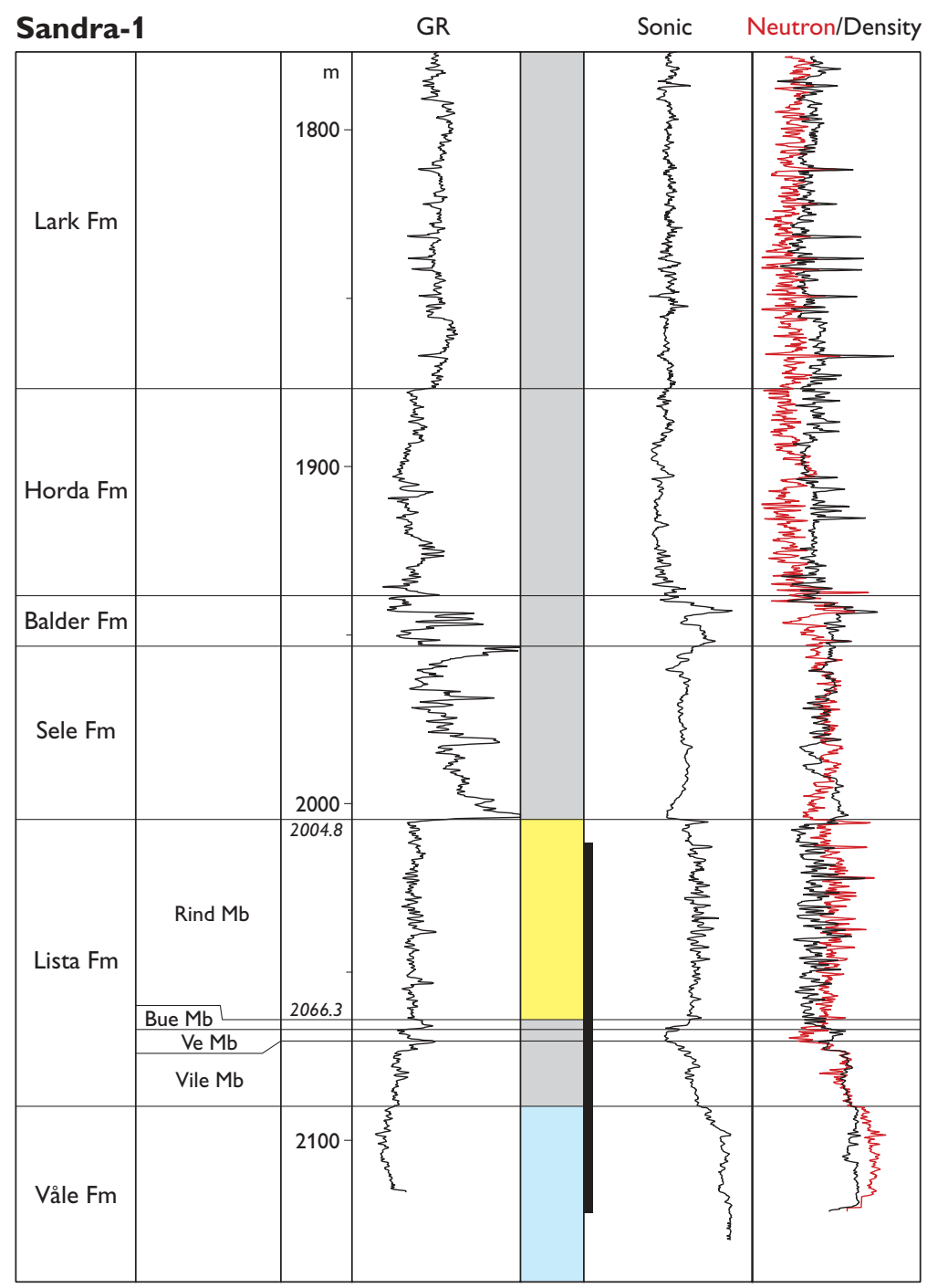

Fig. 33. Sandra-1, reference well for the Rind Member. Black bar shows cored section.

sharp and characterised by prominent shifts on both the sonic and density logs (Figs 29, 33). It is often difficult to identify the boundaries on the gamma-ray log alone.

Depositional environment. Although the sandstones of the Rind Member were deposited from highly concentrated gravity flows, their present appearance largely records postdepositional liquefaction and fluidisation processes.

Age. Thanetian.

Correlation. The Rind Member may be contemporaneous with parts of the lithologically dissimilar Østerrende Clay encountered in the Storebælt region (Fig. 1), with sandstones in the higher parts of the Heimdal Formation (Hardt et al. 1989) and with the Upper Balmoral Sandstone of the Mey Sandstone Member of Knox \& Holloway (1992). However, the Rind Member is not contiguous with those sandstone units and has a different source area.

\section{Sele Formation}

History. The Sele Formation was established by Deegan \& Scull (1977) for the dark grey to greenish grey, laminated and carbonaceous, tuffaceous, montmorillonite-rich shales and siltstones that overlie the non-laminated and nontuffaceous shales of the Lista Formation in some areas, or arenaceous sediments belonging to a variety of different units in other areas. The original definition of the Sele boundary is followed herein. This implies that the base of the Sele Formation is located at the base of the "laminated tuffaceous shales" that overlie the "non-laminated, nontuffaceous shales" of the Lista Formation (Deegan \& Scull 1977; see Boundaries section under the Lista Formation for further details). Sandstones occur in the Sele Formation in the Danish sector; these are established as a new member, the Kolga Member.

Type well. British sector well 21/10-1,2131-2100 m MDKB. 
Danish reference wells. Siri-1, 2072.6-2047.5 m MDKB

(Fig. 14; Plates 1, 4); Tabita-1, 2958.8-2941.4 m MDKB (Fig. 34; Plate 2).

Distribution and thickness. The Sele Formation is recognised from a large number of North Sea wells and it has a basinwide distribution. In the Danish sector, the thickness varies from 5 to $54 \mathrm{~m}$ (Fig. 35).

Lithology. The Sele Formation consists of medium to dark grey, brownish or black laminated mudstones. Thin tuff layers occur in the upper part of the formation. It contains three or more well-laminated intervals where dark mudstone beds alternate with lighter coloured mudstone beds. The well-laminated intervals are enriched in organic material resulting in a high gamma-ray response, primarily due to increased uranium content. The most organic-rich, and often darkest, most well-laminated interval is found in the basal part of the formation (Fig. 36). The mudstones of the Sele Formation show an overall upward increase in the silt fraction. In the upper half of the formation, the mudstones may be interbedded with thin, very fine-grained sandstone laminae and thin sandstone beds (Fig. 37). The sandstone beds are up to $12 \mathrm{~cm}$ thick, normally graded and display parallel lamination. Locally, and dominantly in the upper part of the formation, graded tuff laminae less than $1 \mathrm{~cm}$ thick are present. In cores, the tuff laminae have a light purple colour. Small calcite concretions are present, but rare. In the Siri Canyon, the Sele Formation is interbedded with sandstones or it grades upwards into a succession of thinly interbedded sandstones and mudstones. Thin sandstone intrusions occur, but only in the lower part of the formation.

Log characteristics. The Sele Formation is characterised by high gamma-ray readings throughout, with a number of gamma-ray peaks. On the gamma-ray log, the base of the Sele Formation is generally marked by a conspicuous upward shift to consistently higher gamma-ray readings than those of the underlying Bue Member (Figs 38, 39). In most wells, a pronounced gamma-ray peak follows a short distance above the base of the Sele Formation (e.g. Augusta-1 and E-8; Fig. 38). In wells to the north and west of the Danish sector, the stratigraphic distance between the shift to higher gamma-ray readings at the base of the Sele Formation and the gamma-ray peak is considerably greater (e.g. in the Norwegian well 2/7-1; Fig. 25). In some wells in the Danish sector (and in most Siri Canyon wells), the basal high gamma-ray interval is missing and the base of the Sele Formation is marked by the pronounced gamma-ray peak (e.g. Cleo-1 and Nini-3; Figs 38, 39).

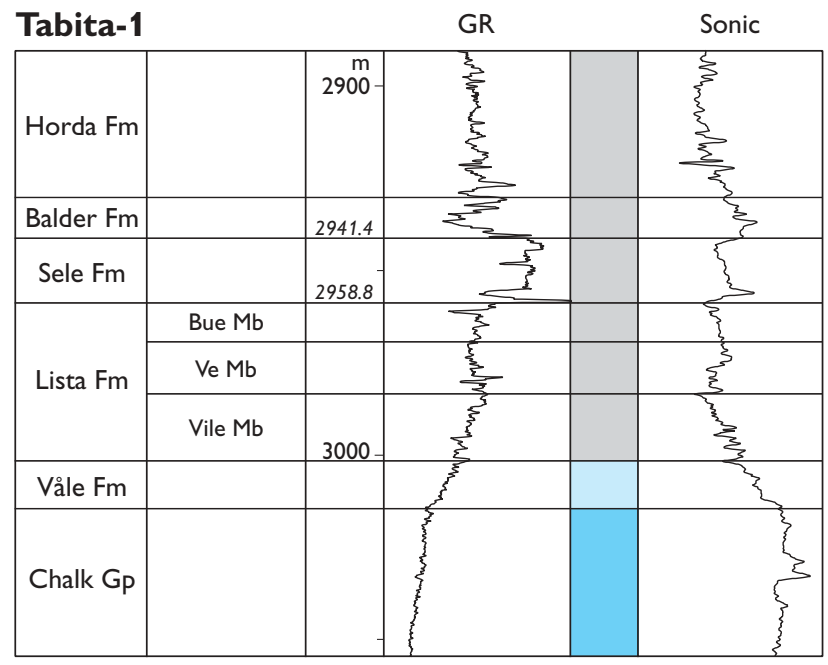

Fig. 34. Tabita-1, Danish reference well for the Sele Formation.

Boundaries. The lower boundary is characterised by a change from the light to dark grey and greyish black mudstones with thin sandstone laminae of the Bue Member (Lista Formation), to dark grey to black well-laminated mudstones without sandstone laminae of the Sele Formation (Fig. 36). The upper boundary is at the base of the Balder Formation.

Subdivision. Knox \& Holloway (1992) suggested an informal threefold subdivision of the Sele Formation based

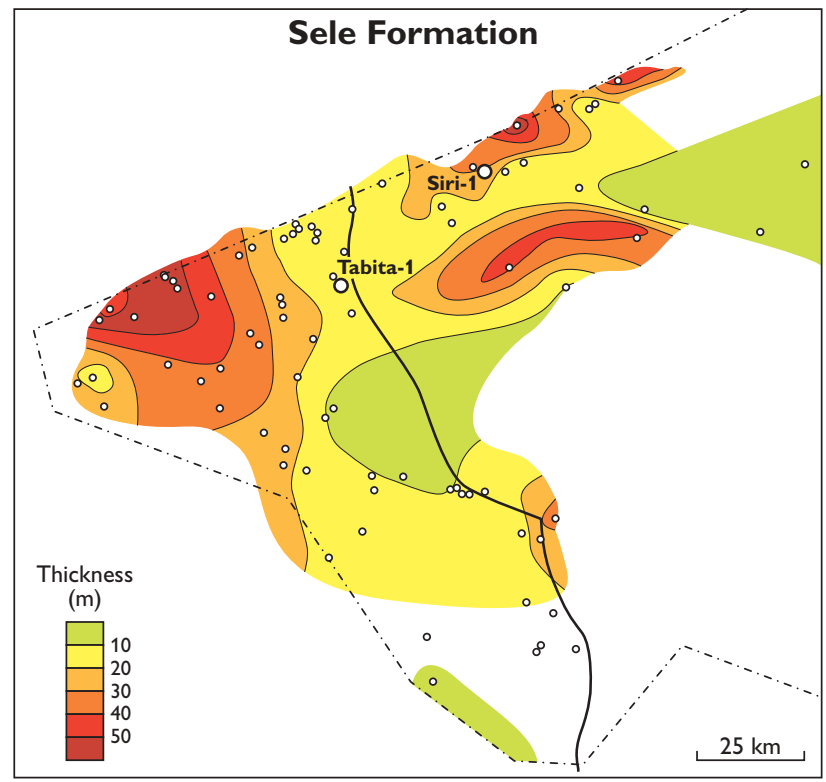

Fig. 35. Isochore map of the Sele Formation in the study area. The positions of the two Danish reference wells, Siri-1 and Tabita-1, are indicated in the figure. 


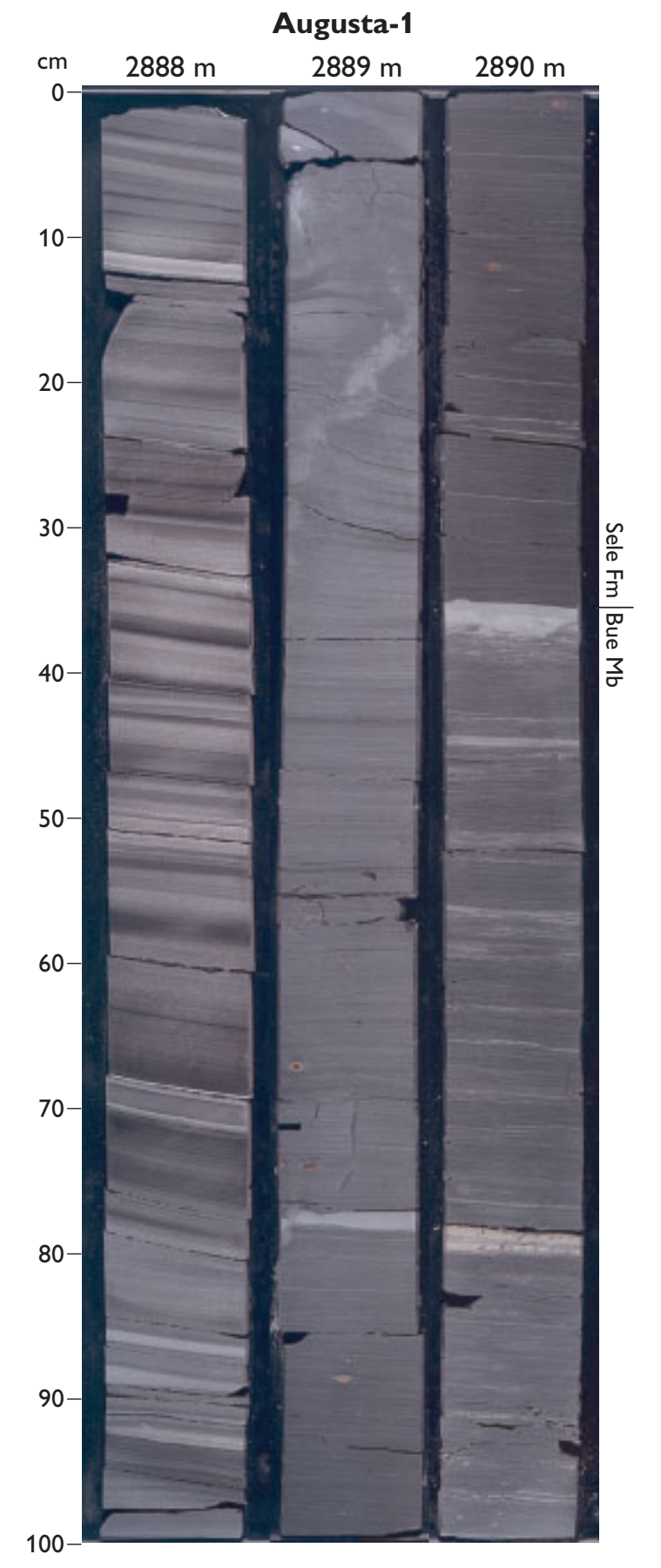

Fig. 36. Core photographs of the Lista-Sele formation boundary interval in the Augusta- 1 well. The upper part of the Bue Member (Lista Formation) consists of mudstones with thin sand- and siltstone laminae superficially resembling mudstone-in-mudstone lamination. At $2890.35 \mathrm{~m}$, the Bue Member is overlain sharply by the laminated mudstones of the Sele Formation. Depths are core depths.

on the gamma-ray log signature. This subdivision can also be recognised on petrophysical logs from most wells in the Danish sector (the subdivision is shown in five wells in Figs 24, 26 and 38), whereas other lithological changes are more subtle. The subdivision is outlined below.

\section{Unit S1}

This unit comprises a lower subdivision S1a and an overlying subdivision S1b. Subdivision S1a is identical to the Bue Member of the Lista Formation and the stratigraphic interval from the base of the Sele Formation (sensu Deegan \& Scull 1977) up to the base of the lowermost conspicuous gamma-ray peak within that formation (Fig. 38). That peak is associated with relatively low sonic values. Subdivision S1b has its base at the gamma-ray peak and its top at the base of the next gamma-ray peak. The gamma-ray response decreases up through S1b. Unit $S 1$ consists of brownish grey to dark grey and black, well-laminated mudstones.

\section{Unit S2}

The base of the unit is at the base of the second gamma-ray peak. This peak can be differentiated from the gamma-ray peak at the base of $S 1 b$ by its association with high sonic values. Unit S2 can be divided into a lower subdivision (S2a) characterised by a relatively high gamma-ray response level and an overlying subdivision (S2b) with a lower gamma-ray response (Fig. 38). The two subdivisions are separated by a gammaray low. Unit S2 consists of light grey to brownish dark grey, laminated to well-laminated mudstones. Both the lamination and the colour of the two subdivisions are very similar in the cores encountered in this study and it is almost impossible to distinguish the two subdivisions on lithology alone. Knox \& Holloway (1992) observed tuff layers in the basal part of unit S2b in the British wells; tuffs were not observed in the Danish wells..

\section{Unit S3}

This unit is characterised by high and increasingupwards gamma-ray values. The base of the unit is defined by a sharp increase in gamma-ray readings (Fig. 38). There is no significant colour difference between the mudstones of units S2 and S3 in the Danish wells, but lamination seems to be better developed in unit S3 than in unit S2. Tuff layers were observed in unit S3 in the British wells studied by Knox \& Holloway (1992). Similar tuff layers have been observed in wells from the Siri Canyon, and may further be used to distinguish unit $\mathrm{S} 3$ from the upper part of unit $\mathrm{S} 2$. 
The Sele Formation includes a sandstone unit (Kolga Member, new) in the Danish North Sea sector.

Macro- and ichnofossils. Fish scales and skeletal fragments are common in cores from the Sele Formation. Bioturbation is very rare, but Chondrites ispp. has been observed locally.

Microfossils and palynomorphs. Benthic foraminifers are rare in the Sele Formation. The LO of an acme of the dinoflagellate genus Apectodinium and the coeval LO of the shortranged $A$. augustum mark a level at, or a few centimetres above the base of the Sele Formation. The HO of $A$. augustum is located in the lower part of the Sele Formation. The $\mathrm{HO}$ of an influx of the dinoflagellate Cerodinium wardenense marks a level in the upper part of the Sele Formation. The $\mathrm{HO}$ of an influx of the diatoms Fenestrella antiqua and Coscinodiscus morsianus is located in the uppermost part of the Sele Formation. Throughout, the formation contains abundant spores and pollen, in particular pollen of the genus Inaperturopollenites.

Depositional environment. The mudstones of the Sele Formation represent a mixture of pelagic fallout and dilute, low-density mud turbidites. The well-laminated character of the sediment, the high content of organic material and uranium, and the general lack of trace fossils and benthic foraminifers indicate starved sedimentation under dysoxic to anoxic bottom conditions. Common diatoms indicate a high nutrient level in the water mass.

The tuffs of the Sele Formation are evidence of extensive volcanism in the region. The significant depauperation of the benthic microfaunas during the deposition of the Sele Formation was most likely caused by isolation of the North Sea Basin (Schmitz et al. 1996). The restriction and isolation of the basin was the result of a sea-level fall, possibly combined with (or caused by) tectonic uplift to the north-west (Knox et al. 1981). Based on microfossils, the palaeoenvironment has been suggested to represent an upper bathyal setting with a palaeodepth estimate of around $300 \mathrm{~m}$ (Mitlehner 1996). The palynomorph assemblage indicates a marine environment characterised by a massive influx of terrestrial palynomorphs.

Age. Sparnacian (sensu Aubry et al. 2003) - early Ypresian, with the lowermost level possibly of Thanetian age.

Correlation. The Sele Formation corresponds to the Haslund Member of the Ølst Formation (Heilmann-Clausen et al. 1985). Its upper part correlates with the Haslund Member-equivalent diatomitic Knudeklint Member of the

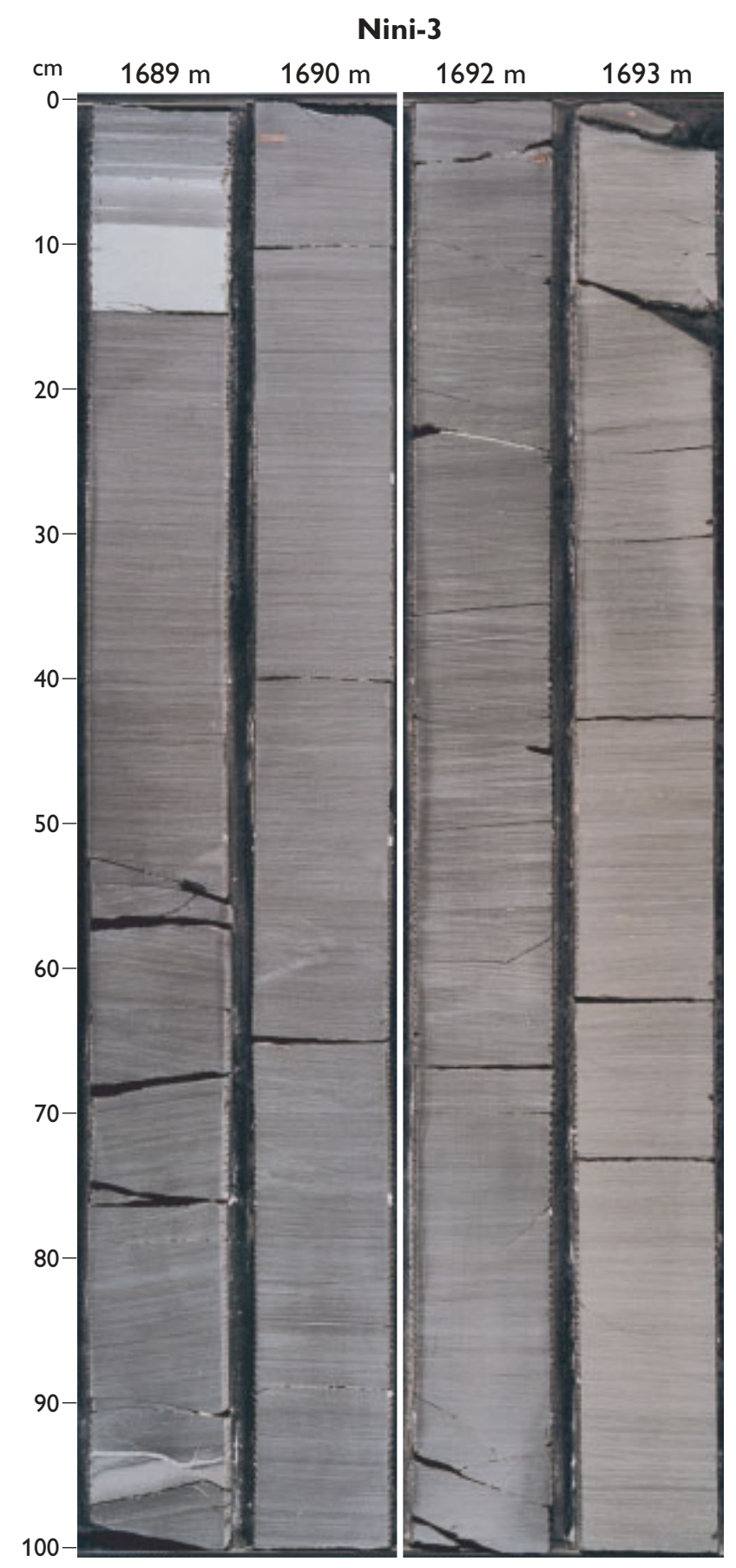

Fig. 37. Core photographs from the Nini-3 well showing the upper, arenaceous part of the Sele Formation. The interval belongs to the S2a subunit of the Sele Formation (see text for further explanation). Stratigraphic position of the figured interval is shown in Fig. 39. Depths are core depths.

Fur Formation in north-west Jylland (Danielsen \& Thomsen 1997). The lower boundary of the Sele Formation correlates with the boundary between the Østerrende Clay and the Haslund Member onshore Denmark. 


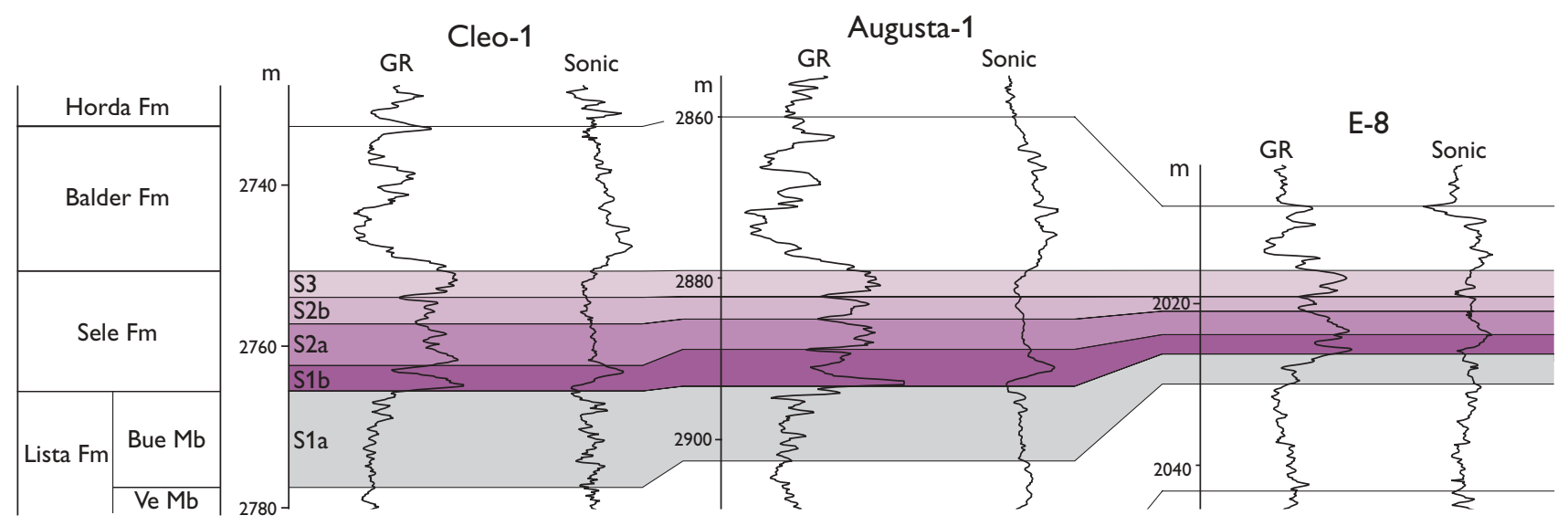

Fig. 38. Correlation diagram of the Sele Formation showing the Sele units S1-3 of Knox \& Holloway (1992).

The lower part of the Sele Formation, consisting of laminated, dark grey to black mudstones, correlates with the lithologically very similar, $15 \mathrm{~m}$ thick informal unit Stolle Klint Clay that constitutes the lower part of the Haslund Member, onshore Denmark (Heilmann-Clausen 1995). This unit is known from throughout the North Sea (Hardt et al. 1989; Knox \& Holloway 1992) and constitutes most or all of the Sele S1b unit of Knox \& Holloway (1992).

\section{Kolga Member}

new member

History. The Kolga Member consists of sandstone deposits within the Sele Formation. These sandstones were previously recognised by a stratigraphic working group at Statoil Norway in the mid-1990s and were informally referred to the Hermod Formation of Hardt et al. (1989).

Derivation of name. After the goddess Kolga.

Type well. Danish sector well Siri-3, 2066.4-2036.1 m MDRT (Fig. 24; Plate 4).

Reference well. Danish sector well Nini-3, 1717.2-1700.4 m MDRT (Figs 26, 39; Plate 4).
Distribution and thickness. The Kolga Member has a restricted distribution in the Siri Canyon in the northern part of the Danish sector (Fig. 20c). It reaches a thickness of up to $30 \mathrm{~m}$.

Lithology. The member consists primarily of fine-grained to very fine-grained, olive-green to greenish grey, well-sorted, quartz-rich sandstones (Fig. 39). Rounded and translucent quartz grains dominate the mineralogical assemblage, but the content of glaucony grains is high (15$25 \%$ ). Mica and small pyrite concretions are present in small amounts. Locally, the sandstones are partly cemented by calcite and chlorite. The member usually includes one thick unit composed of amalgamated sandstone beds and a number of thinner sandstone beds interbedded with mudstones that are lithologically comparable to the Sele Formation mudstones described above.

Log characteristics. The Kolga Member is clearly defined on the gamma-ray log by a blocky pattern with intermediate values. This pattern differs from the high gamma-ray readings that normally characterise the lower Sele Formation. The Kolga Member may show a gradual upward decrease in gamma-ray response in its lower part (e.g. in the well Nini-3; Figs 26, 39). However, this does not reflect grain-size change, judging from core examination. The density log shows a blocky pattern with low density 
Fig. 39. Core log of the sandstonedominated Kolga Member encased in the Sele Formation mudstones in the Nini-3 well. For legend, see Fig. 9. Intervals marked by grey bars in the core depth column are shown as core photos in Fig. 37.

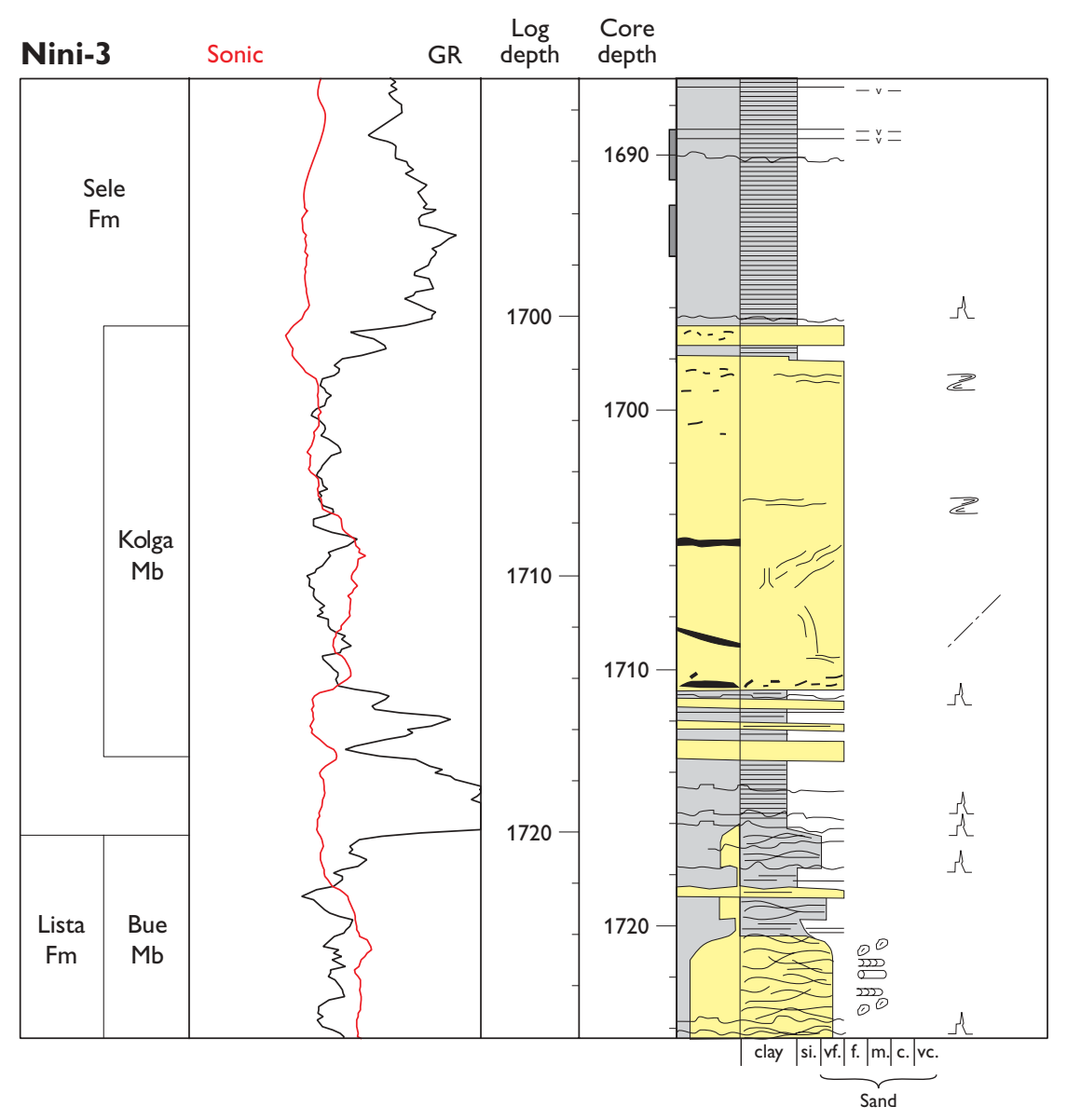

Correlation. The Kolga Member is contemporaneous with parts of the Sele Formation onshore Denmark. It possibly correlates with the Forties Sandstone Member (Knox \& Holloway 1992) in the Central Graben and with the Teal and Skadan Sandstone Members (Knox \& Holloway 1992) in the southern Viking Graben. However, the Kolga Member is not contiguous with those units and has another source area.

\section{Fur Formation}

History. The Fur Formation is a marine diatomite with numerous ash layers. It was formally established by Pedersen \& Surlyk (1983) with a type section in the coastal cliff Knudeklint on the island of Fur, Denmark. Its lower boundary was revised by Heilmann-Clausen et al. (1985). The characteristic lithology of the Fur Formation was subsequently recognised by Thomsen \& Danielsen (1995; Danielsen \& Thomsen 1997) in cuttings samples from three offshore wells located in the north-eastern part of the Danish sector of the North Sea, as well as in one well in the Norwegian sector.

Age. Sparnacian (sensu Aubry et al. 2003) possibly including the latest Thanetian. 


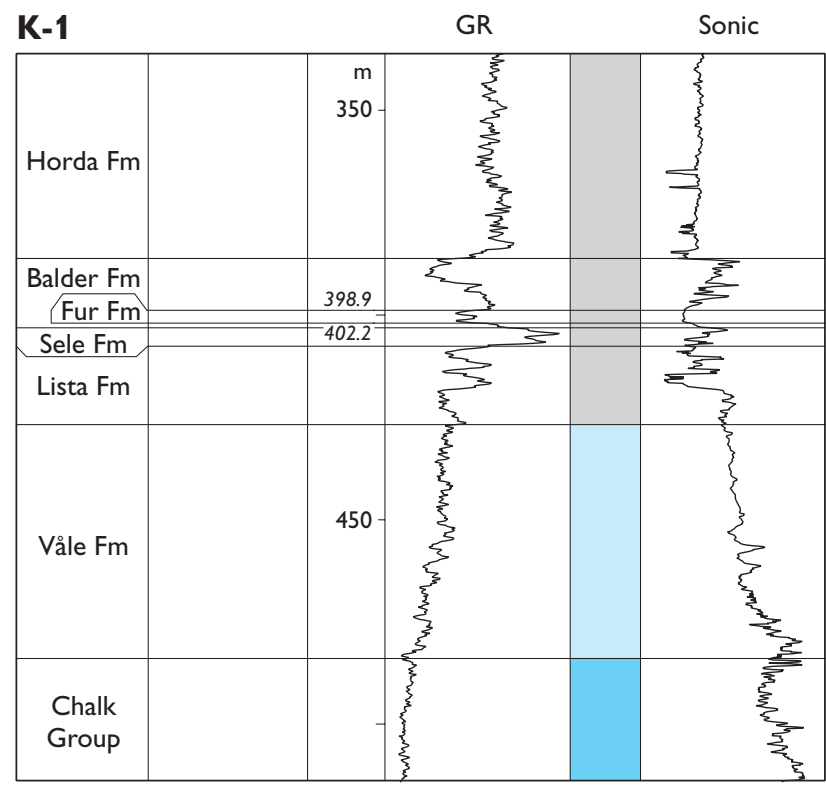

Fig. 40. K-1, reference well for the Fur Formation.

Type section. The coastal cliff Knudeklint, the island of Fur, onshore Denmark (for location map, see Pedersen \& Surlyk 1983).

Reference sections. Silstrup south cliff, Skarrehage, Feggeklit, Harhøj, Stolleklint (for location maps, see Pedersen \& Surlyk 1983).

Danish reference wells. Danish sector wells K-1, 402.2398.9 m MDKB (Fig. 40; Plate 5); Inez-1, 810.7-795.3 m MDKB (Fig. 41; Plates 1, 5).

Distribution and thickness. Onshore Denmark, the Fur Formation is distributed in a limited area in north-west Jutland. It is $c .61 \mathrm{~m}$ thick in its type section. Offshore, the formation occurs in a belt stretching from the northwestern coast of Jutland, continuing into the Norwegian sector parallel to the southern coast of Norway (Thomsen \& Danielsen 1995 text-fig. 6; Fig. 42). It reaches a thickness of $15.4 \mathrm{~m}$ in the Inez-1 well, $7.9 \mathrm{~m}$ in the C-1 well and $3.3 \mathrm{~m}$ in the K-1 well (Figs 40-42).

Lithology. The lithology of the Fur Formation was described from its onshore exposures by Pedersen (1981) and Pedersen \& Surlyk (1983). It is a clayey, porous, dark grey diatomite with numerous volcanic ash layers. Diatom frustules constitute $65 \mathrm{wt} \%$ of the rock, clay particles constitute $35 \mathrm{wt} \%$ (Pedersen 1981). Tests of Coscinodiscus spp. and Stephanopyxis are the major constituent of the diatomite fraction (Thomsen \& Danielsen 1995). Fine lamination is the primary sedimentary structure, but at some

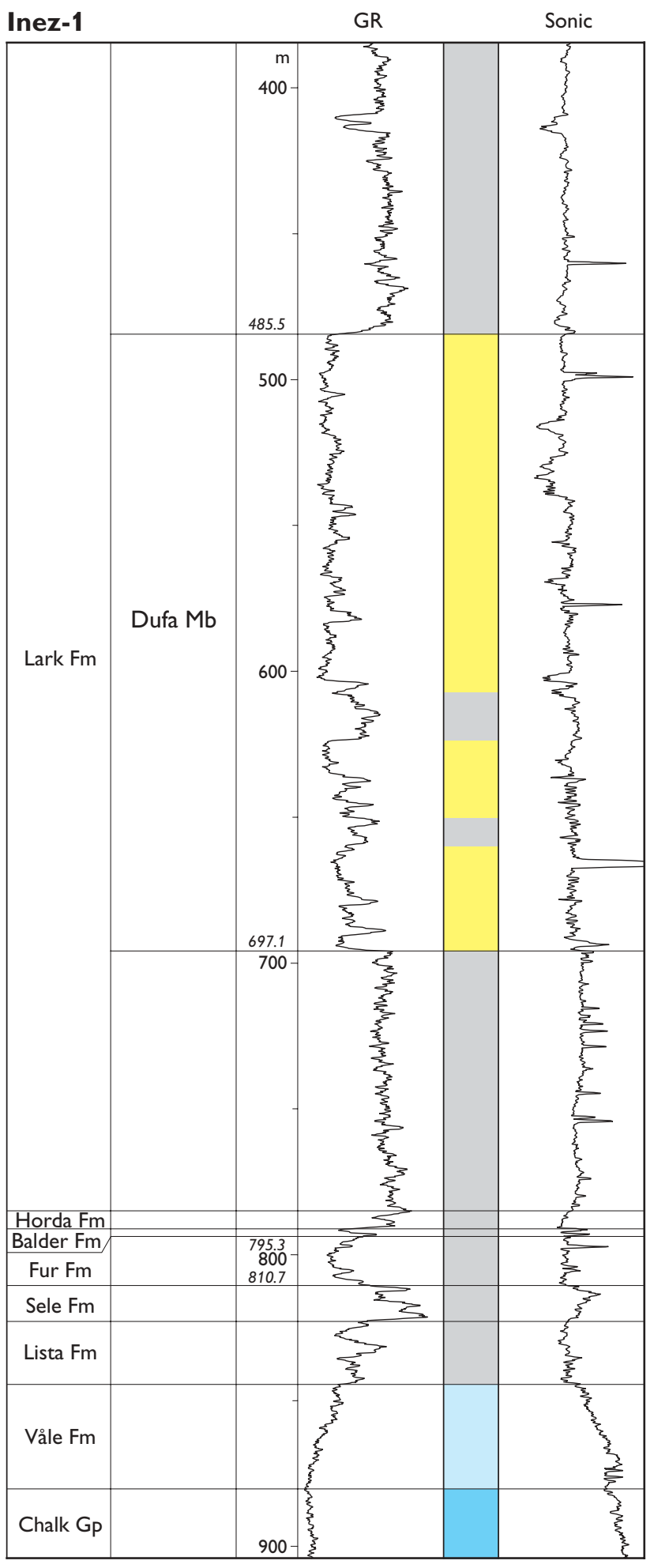

Fig. 41. Inez-1, reference well for the Fur Formation and type well for the Dufa Member. 
levels the lamination has been destroyed by bioturbation. The ash layers are black, graded and consist of volcanic glass particles. Individual layers range from $1-20 \mathrm{~cm}$ in thickness but are fairly uniform in thickness over a limited area (Pedersen $\&$ Surlyk 1983). The diatomite recognised in cuttings samples from North Sea wells by Thomsen \& Danielsen (1995) is a similar lithology to that of the onshore sections studied by Pedersen (1981) and Pedersen \& Surlyk (1983).

Log characteristics. The Fur Formation is identified by the combination of a low gamma-ray response and low sonic readings within an interval of higher sonic readings characterising mudstones below and above (Thomsen \& Danielsen 1995; Danielsen \& Thomsen 1997; Figs 40, 41; Plates 1, 5).

Boundaries. In the C-1 and K-1 wells, the Fur Formation is enveloped by the Balder Formation. In Inez-1, the formation is bounded by the Sele and Balder Formations (Figs 40, 41; Plates 1, 5). It should be noted, however, that Thomsen \& Danielsen (1995 text-fig. 4) and Danielsen \& Thomsen (1997 fig. 5) placed the Fur Formation entirely within the Sele Formation in the K-1 well. The discrepancy between the interpretation herein and that of the former authors is due to different interpretations of the position of the Balder-Sele boundary in the well. The boundary of the Fur Formation with the Balder and Sele Formations is characterised by a change from laminated or structureless diatomite with ash layers to the dark mudstones of the Balder and Sele Formations. This lithological change is reflected on the sonic log by an abrupt increase in velocity (Figs 40, 41; Plates 1, 5).

Subdivision. Onshore Denmark, the Fur Formation is divided into the lower, laminated Knudeklint Member that contains relatively few, widely spaced ash layers and the upper, mainly structureless Silstrup Member with numerous ash layers (Pedersen \& Surlyk 1983).

Macro-andichnofossils. The macrofossil assemblage described from onshore exposures of the Fur Formation encompasses fish, birds, turtles, snakes, starfish, shellfish, snails, mussels, crabs, pteropods, insects, fossil wood, leaves and fructifications (Bonde 1966, 1979, 1987, 2003; Pedersen 1981; Pedersen \& Surlyk 1983; Kristoffersen 2001). Ichnofossils from onshore exposures include Planolites ispp., Teichichnus ispp., Chondrites ispp. and Taenidium ispp. (Pedersen \& Surlyk 1983).

Microfossils and palynomorphs. Diatom frustules are rockforming in the Fur Formation (Pedersen 1981). Silico-

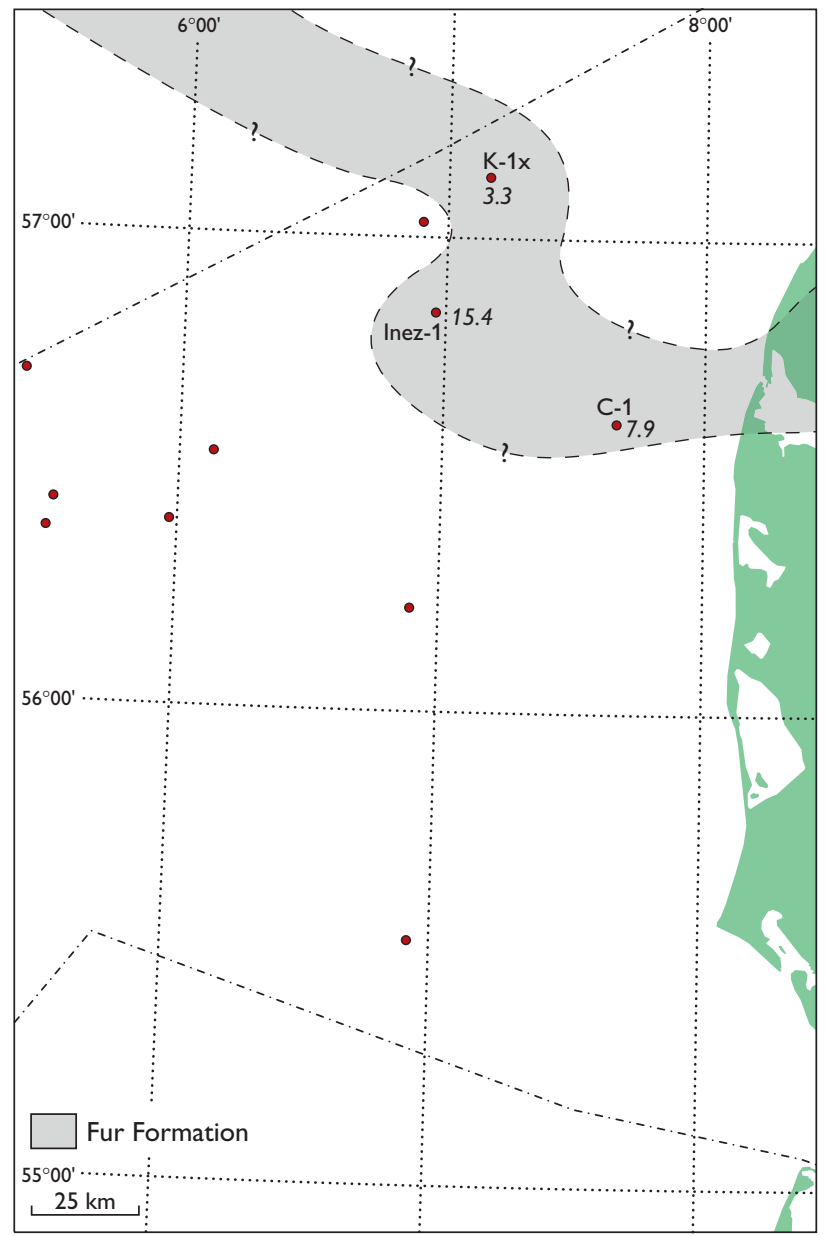

Fig. 42. Distribution map of the Fur Formation with formation thickness $(\mathrm{m})$ indicated for three wells.

flagellates are present (Perch-Nielsen 1976) whereas calcareous microfossils are absent. The formation contains abundant dinoflagellates and sporomorphs (Hansen 1979; Heilmann-Clausen 1982; Willumsen 2004).

Depositional environment. The deposition of the Fur Formation diatomites took place in a long, narrow zone under upwelling conditions (Bonde 1974, 1979). The upwelling was controlled by northerly winds (Bonde 1974, 1979) or it may have been created by a combination of bottom currents and bottom topography (Pedersen \& Surlyk 1983).

Age. Early Ypresian.

Correlation. Onshore Denmark, the Knudeklint and Silstrup Members are largely contemporaneous with the upper part of the Haslund Member and the overlying Værum Member of the Ølst Formation (HeilmannClausen et al. 1985), respectively, and correlate with the 


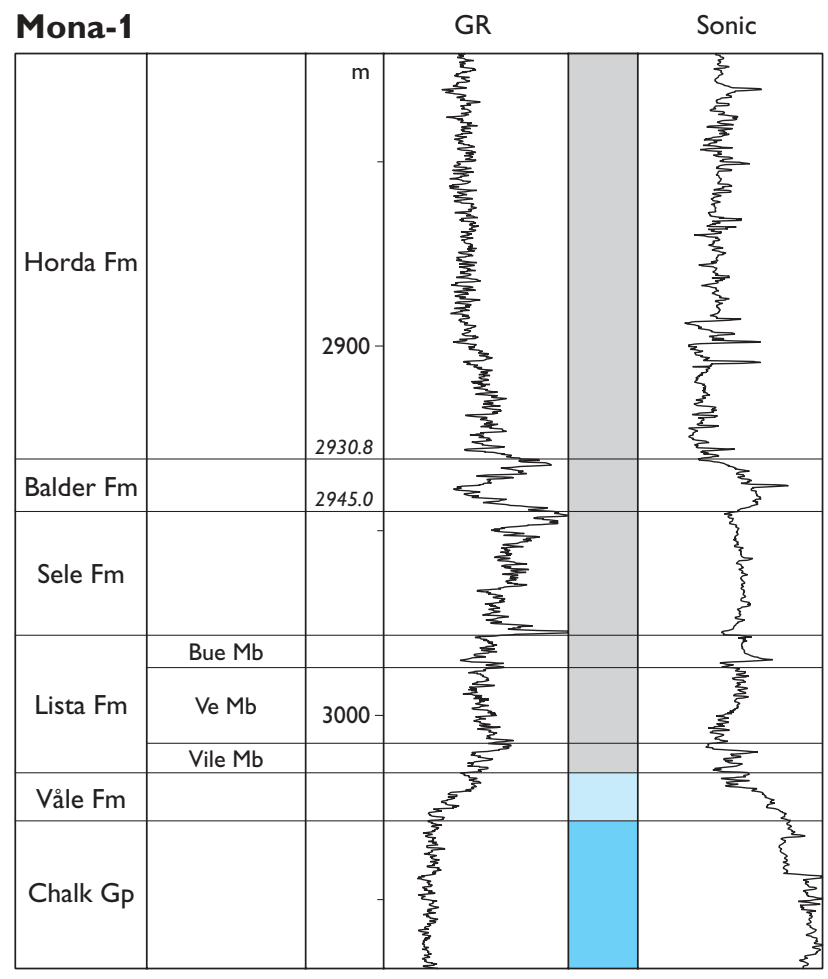

Fig. 43. Mona-1, Danish reference well for the Balder Formation.

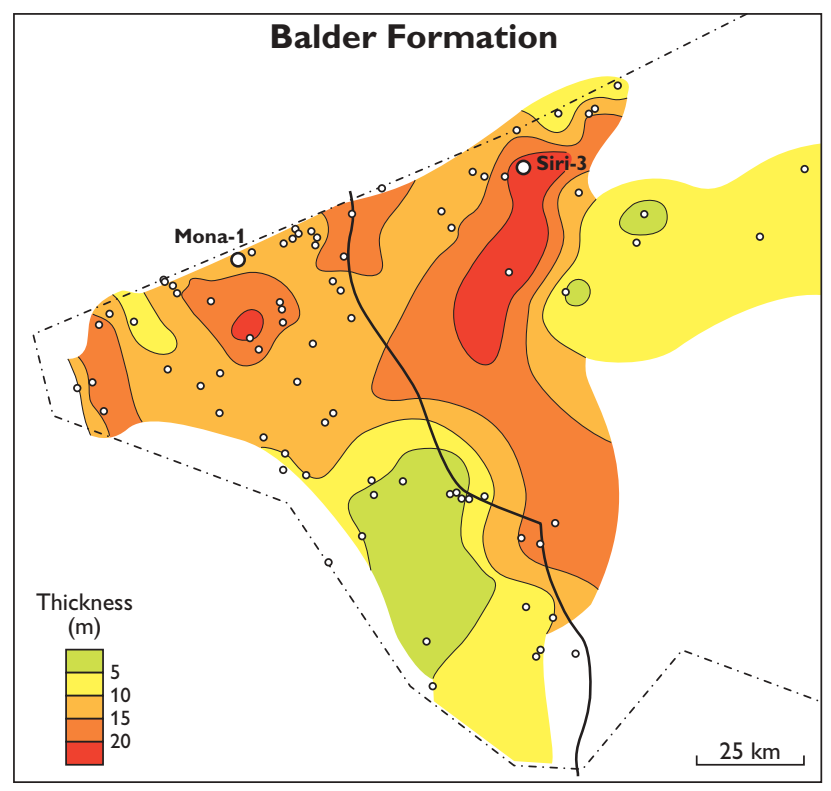

Fig. 44. Isochore map of the Balder Formation in the study area. The positions of the two Danish reference wells, Mona-1 and Siri-3, are indicated in the figure. upper part of the Sele Formation and the lower unit B1 (see below) of the Balder Formation (Heilmann-Clausen 1995; Knox 1997 fig. 3).

\section{Balder Formation}

History. Deegan \& Scull (1977) established the Balder Formation for the succession of variegated, fissile and laminated shales with interbedded tuff layers that lie between the Sele and Horda Formations.

Type well. Norwegian sector well 25/11-1, 1780-1705 m MDKB.

Danish reference wells. Mona-1, 2945.0-2930.8 m MDKB (Fig. 43; Plate 1). Siri-3, 2016.8-1998.8 m MDRT (Fig. 24; Plate 4).

Distribution and thickness. The Balder Formation extends over most of the central and northern North Sea. In the Danish sector, it reaches a thickness of more than $20 \mathrm{~m}$ in the Siri-3 and Frida-1 wells on the western part of the Ringkøbing-Fyn High (Fig. 1) and $20 \mathrm{~m}$ in Gwen-2 in the northern part of the Danish sector of the Central Graben. The Balder Formation thins to less than $5 \mathrm{~m}$ towards the south-west and to less than $10 \mathrm{~m}$ in the eastern part of the Danish sector of the North Sea. The Balder Formation is lacking in the Danish well S-1 (Michelsen et al. 1998). An isochore map of the Balder Formation is shown in Fig. 44.

Lithology. The Balder Formation is composed of laminated, dominantly grey, fissile shales with interbedded dark and light grey, purple, buff and green sandy tuffs (Fig. 45). The tuffs are normally graded and less than $5 \mathrm{~cm}$ thick. Locally the tuff beds are slumped. The tuff layers may be cut by irregular, vertical, calcite-filled cracks up to $20 \mathrm{~cm}$ long (Fig. 45). Similar cracks have been reported from the Balder Formation in the Grane Field, Norwegian sector of the North Sea (Haaland et al. 2000). Sandstone beds, interpreted as intrusive sandstone bodies, occur locally in the Balder Formation.

Log characteristics. The Balder Formation is characterised by a relatively high gamma-ray values in its lower and higher parts, but shows low values in its middle part. The change in gamma-ray response is normally gradual, but relatively steep. The gamma-ray motif is mirrored by a gradual increase in sonic readings commencing at the formation base, culminating at or slightly below the level of minimum gamma-ray values in the middle part of the 
formation, followed by a gradual decrease towards the top of the formation where the lowest sonic reading is reached. The gamma and sonic motifs together create a characteristic barrel-shaped log pattern (e.g. Figs 24, 33, 38, 43; Plates 1-5).

Boundaries. In general, the boundary with the underlying Sele Formation is gradational, although it can be sharp in some wells. Where gradational, it is placed where the tuff layers become prominent (e.g. Fig. 45). On petrophysical logs, the lower boundary is identified at a significant upward decrease in gamma-ray response accompanied by an increase in sonic readings (e.g. Figs 24, 33, 38, 43). The upper boundary is at the base of the Horda Formation.

Subdivision. Knox \& Holloway (1992) subdivided the Balder Formation into a lower, laminated and tuff-rich unit (B1) and a poorly laminated upper unit (B2). This subdivision can be recognised in a number of Danish wells west of Cecilie-1, but the B2 unit seems to be absent from Danish North Sea wells north-east of, and including, the Cecilie-1 well.

Macro- and ichnofossils. Macrofossils have not been observed. The Balder Formation is non-bioturbated to moderately bioturbated. Ichnofossils comprise Chondrites ispp., Phycosiphon ispp., Planolites ispp. and Thalassinoides ispp.

Microfossils and palynomorphs. The Sele-Balder boundary interval is characterised by the $\mathrm{HO}$ of common Fenestrella antiqua and Coscinodiscus morsianus (both diatoms). This event is located in the uppermost part of the Sele Formation but may be used as a biostratigraphic guide to locate the boundary. The diatom Fenestrella antiqua characterises the Balder Formation and has its $\mathrm{HO}$ at the formation top. The dinoflagellate Deflandrea oebisfeldensis shows an acme at the top of the Balder Formation. As observed in the underlying Sele Formation, the Balder Formation contains high numbers of spores and pollen, in particular pollen of the genus Inaperturopollenites spp., and the top of the Balder Formation is marked by the $\mathrm{HO}$ of common representatives of that genus. In contrast to the overlying Horda Formation, calcareous benthic foraminifers are virtually absent in the Balder Formation.

Depositional environment. A restricted marine palaeoenvironment at upper bathyal depths with dysoxic to anoxic bottom conditions is suggested for the Balder Formation. This is based on the scarcity of calcareous microfossils and agglutinated foraminifers combined with common to abundant siliceous microfossils, especially diatoms. The

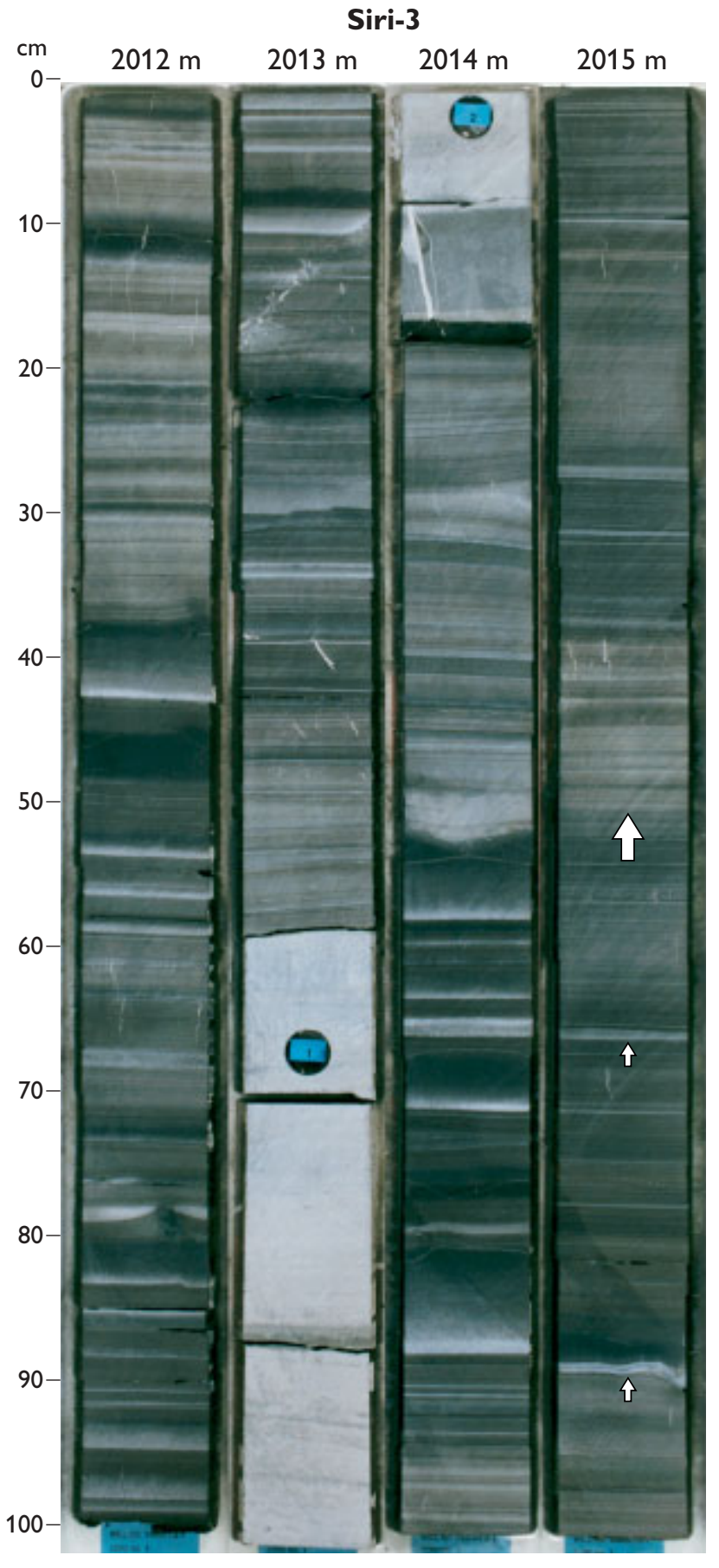

Fig. 45. Core photographs of tuffaceous Balder Formation mudstones from the Siri-3 well. The tuff layers are seen as light coloured, graded intervals (e.g. at 2012.42-2012.40 m). The boundary with the underlying Sele Formation is placed where tuffs become common, at 2015.5 $\mathrm{m}$ (large arrow); two tuff layers may be seen in the uppermost Sele Formation, at 2015.66 and $2015.90 \mathrm{~m}$ (small arrows). Two small, lightning-shaped cracks are seen at $2015.4 \mathrm{~m}$. Depths are core depths. 
Mona-1

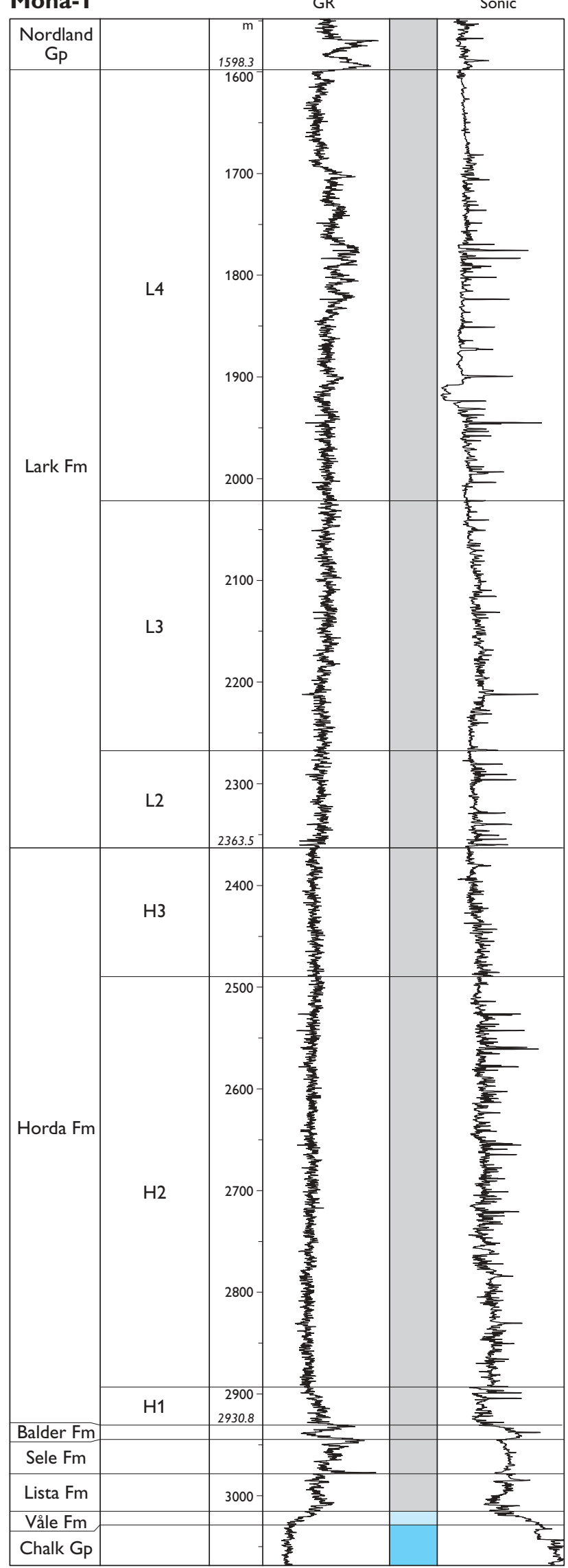

presence of abundant terrestrial palynomorphs further supports a restricted, marginal marine depositional setting.

A petrographic and geochemical study of the Balder Formation in the Grane Field, Norwegian North Sea sector, shows that the tuffs can be classified as representing sub-alkaline basalts and basaltic andesites of intra-plate origin (Haaland et al. 2000). The tuffs are similar to the contemporaneous Lower Basalts in East Greenland, the Rockall Trough and the Middle Series of the Faeroe Islands, all linked to the opening of the North Atlantic (Haaland et al. 2000). The volcanic phase took place at 55-52 Ma.

\section{Age. Early Ypresian.}

Correlation. Although unit B2 of Knox \& Holloway (1992) is apparently lacking in wells in the north-eastern part of the Danish sector, both units B1 and B2 can be correlated with strata onshore Denmark, although unit B2 is very thin. Unit B1 corresponds to the lithologically similar Værum Member of the widespread Ølst Formation onshore Denmark and with the diatomaceous Silstrup Member of the Fur Formation in north-west Jylland (Knox 1997 fig. 3). The lower boundary of the Værum and Silstrup Members is placed at ash layer no. +1 in the tephrachronology of Bøggild (1918). The ash chronology has not been identified in the type section of the Balder Formation and precise correlation with the lower boundary of the Værum and Silstrup members is therefore uncertain. However, judging from the abundance of thick ash layers in the Balder Formation and the scarcity of ash layers in the underlying Sele Formation, it is likely that the base of the Balder Formation approximately correlates with ash layer no. +1 , i.e. with the base of the Værum and Silstrup Members.

According to Knox (1997 fig. 3), unit B2 probably correlates with the Knudshoved Member of the Røsnæs Clay Formation (Heilmann-Clausen et al. 1985). This member has a very restricted distribution in north-west Jylland where it overlies the Silstrup Member of the Fur Formation. The Knudshoved Member consists of a lower dark grey, pyritic clay unit rich in pyritised diatoms, and an upper greenish clay unit (Heilmann-Clausen et al. 1985). Only a few, thin volcanic ash layers are present in the member (Håkansson \& Sjørring 1982). Based on lithological comparison, it is suggested that at least the lower,

Fig. 46. Mona-1, Danish reference well for the Horda and Lark Formations. The figure shows the tripartite subdivision of the Horda Formation and the L2-4 units of the Lark Formation. The L1 unit is absent in the Mona-1 area. 


\section{Siri-1}

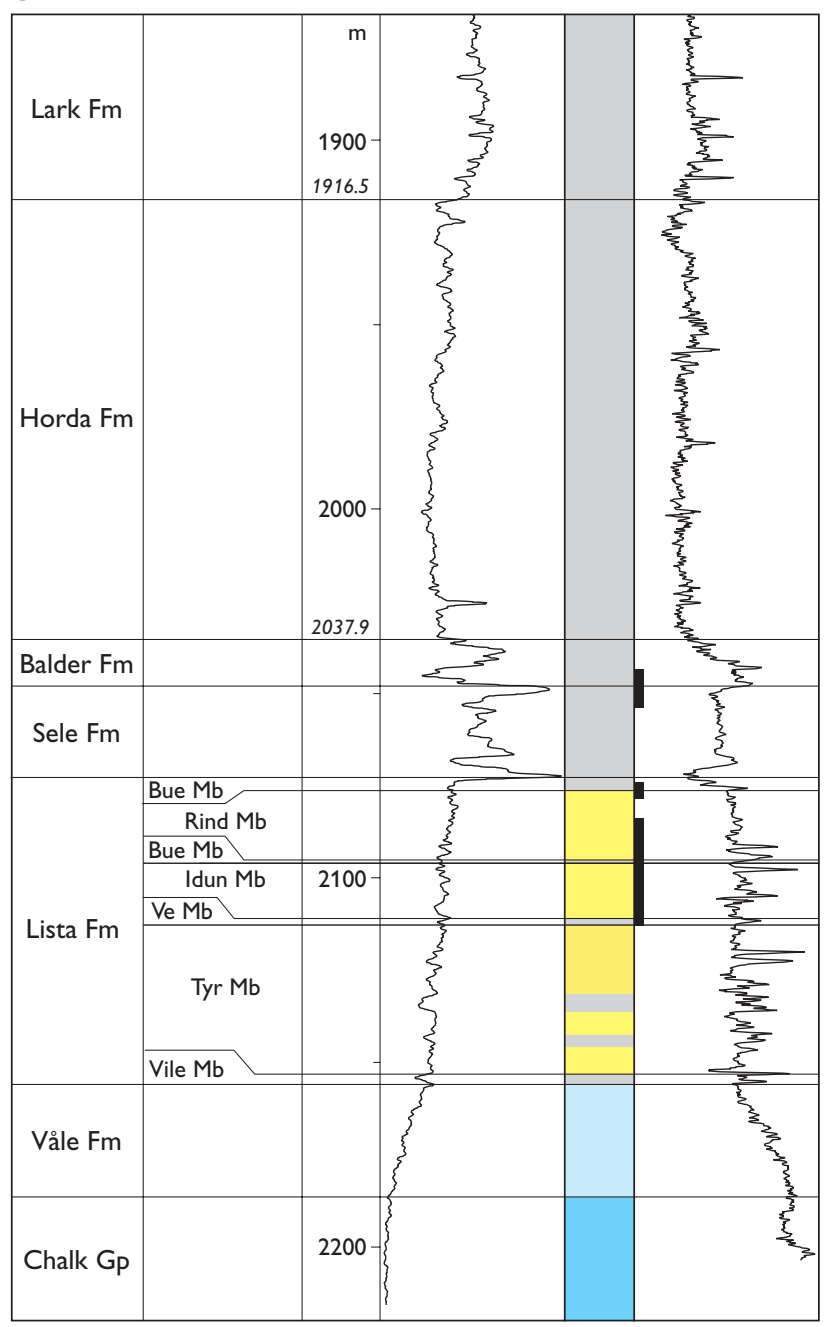

Fig. 47. Siri-1, Danish reference well for the Horda Formation. Black bars show cored sections.

pyritic part of the Knudshoved Member may correlate with the upper, tuff-poor unit B2 of the Balder Formation.

\section{Stronsay Group}

Knox \& Holloway (1992) replaced the Hordaland Group of Deegan \& Scull (1977) with two new groups: the Stronsay Group succeeded by the Westray Group (Fig. 3). The two groups together comprise the light grey, green and brown coloured, soft, fissile, marine shales with thin limestone streaks that overlie the Rogaland Group and underlie the Nordland Group. These groups each contain two formations, one representing sandy shelf lithofacies and the other representing basinal mudstone lithofacies. In the central North Sea, and in the Danish sector, the Stronsay Group is represented by its mudstone facies, the Horda

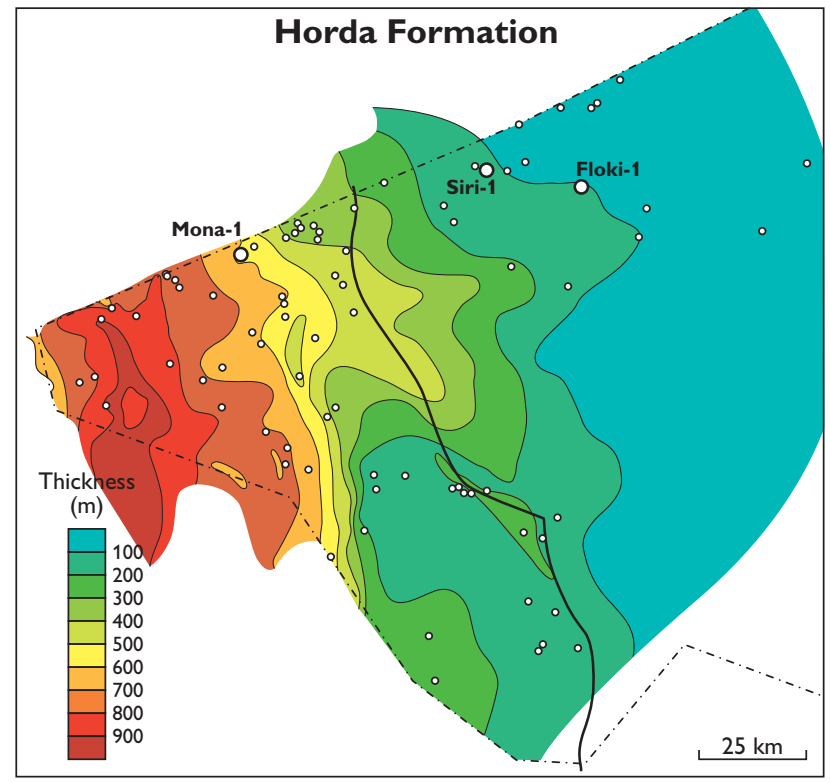

Fig. 48. Isochore map of the Horda Formation in the study area. The positions of the two Danish reference wells for the Horda Formation, Mona- 1 and Siri-1, are indicated on the map. The position of Floki-1, the type well for the Hefring Member, is also indicated.

Formation (Knox \& Holloway 1992). Sandstone units of varying thickness occur at many levels in the Stronsay and Westray Groups along the basin margin in the Norwegian and British sectors, and many of these have been defined as formations or members (Deegan \& Scull 1977; Hardt et al. 1989; Knox \& Holloway 1992). A sandstone unit also occurs in the Horda Formation on the Ringkøbing-Fyn High in the Danish sector and is described here as a new member (Hefring Member).

\section{Horda Formation}

History. Knox \& Holloway (1992) established the Horda Formation for the greenish grey basinal mudstone facies of their Stronsay Group that overlies the grey tuffaceous mudstones of the Balder Formation and underlies the greenish grey to brown mudstones of the Lark Formation (Knox \& Holloway 1992).

Type well. British sector well 22/1-1A, 2379.5-1992 m MDKB.

Danish reference wells. Mona-1, 2930.8-2363.5 m MDKB (Fig. 46); Siri-1, 2037.9-1916.5 m MDKB (Fig. 47).

Distribution and thickness. The Horda Formation extends over the central and northern North Sea and is present in 


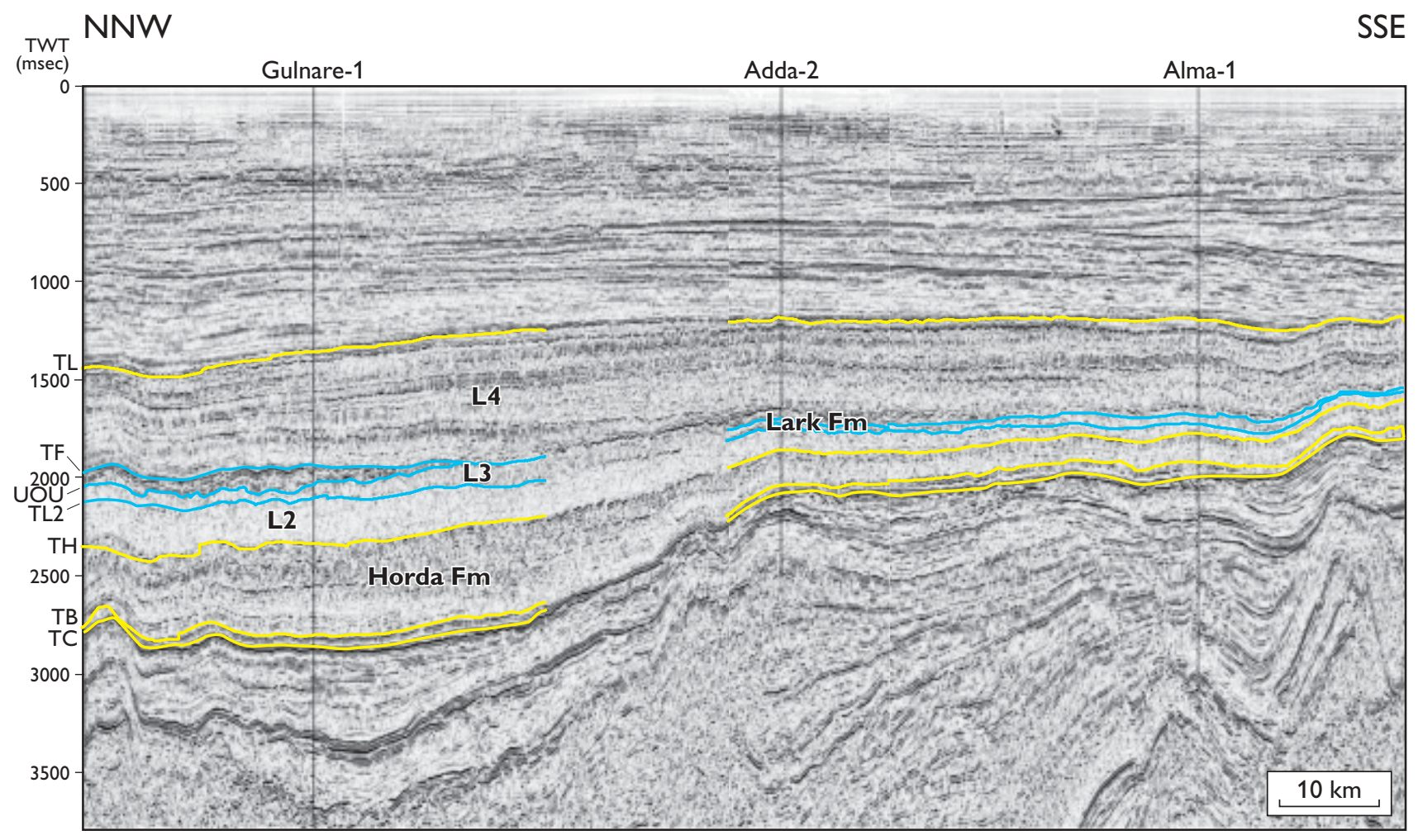

Fig. 49. NNW-SSE-trending seismic section (RTD81-RE94-17A) in the Central Graben showing south- and eastward thinning of the Horda Formation. The location of the seismic section is shown in Fig. 1. The L2, L3 and $\mathbf{L 4}$ subunits of the Lark Formation are indicated, as well as the mudstone-equivalent of the Freja Member. TL, Top Lark; TF, Top Freja; UOU, Upper Oligocene Unconformity; TL2, Top L2; TH, Top Horda; TB, Top Balder; TC, Top Chalk.

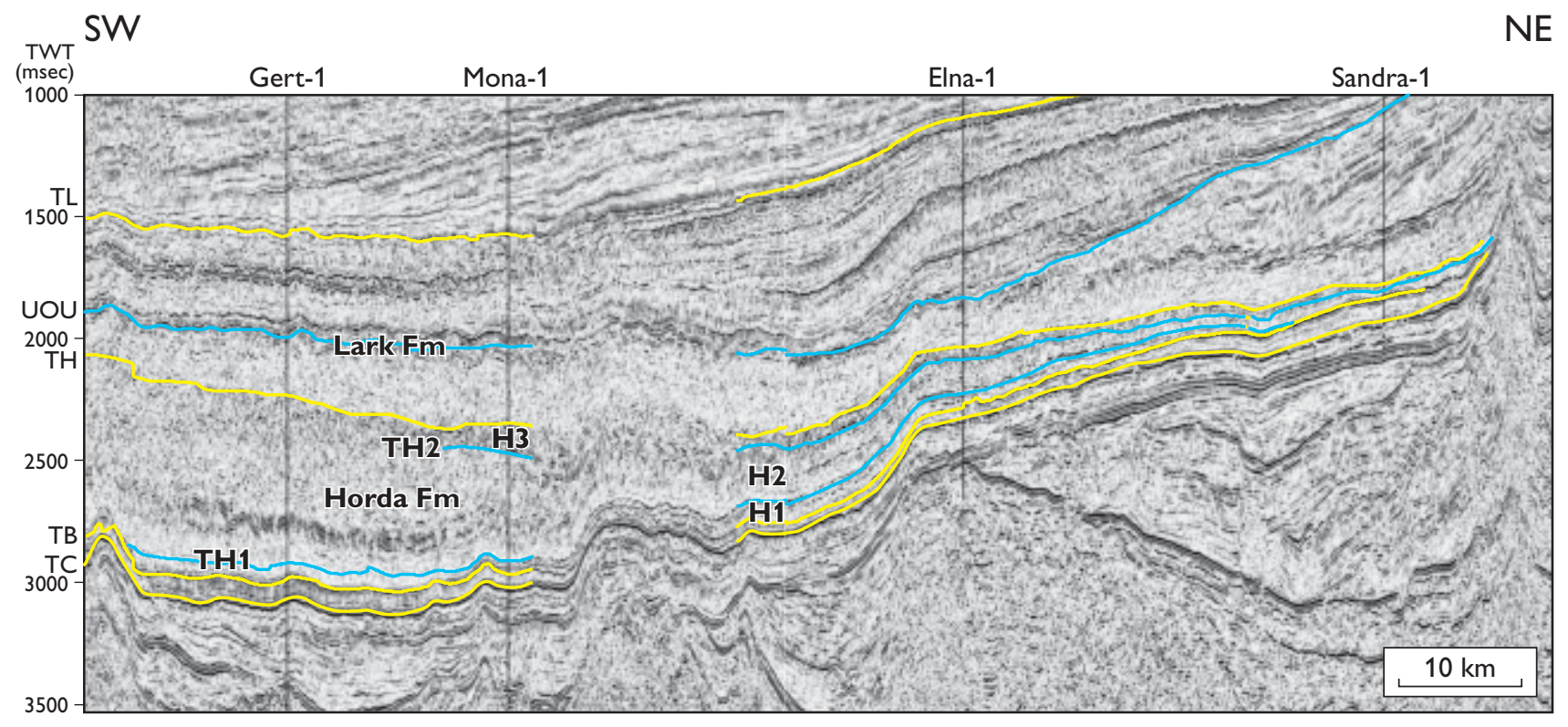

Fig. 50. SW-NE-trending seismic section (RTD81-RTD94-19A) showing the tripartite subdivision (H1-3) of the Horda Formation in the eastern part of the Danish Central Graben (Gert-1 and Mona-1) and pronounced thinning of the Horda Formation east of the Central Graben (Elna-1 and Sandra-1). The location of the seismic section is shown in Fig. 1. TH1, Top H1 marker; TH2, Top H2 marker; other abbreviations as in Fig. 49. 
all wells in the Danish sector of the North Sea. However, the lower part of the Horda Formation (Fig. 4; equivalent to Sequence 2 of Michelsen et al. 1998) is lacking in the eastern wells R-1 and S-1 and in the eastern part of the Ringkøbing-Fyn High. The upper part of the Horda Formation (Fig. 4; equivalent to Sequence 3 of Michelsen et al. 1998) is thin or absent in the same area (Michelsen et al. 1998). The Horda Formation reaches a thickness of $906 \mathrm{~m}$ in the Central Graben well Tordenskjold-1, but thins towards the east and south-east to less than $100 \mathrm{~m}$, with minimum recorded thicknesses of $9 \mathrm{~m}$ in the Ida-1 well and $4 \mathrm{~m}$ in the S-1 well. An isochore map of the Horda Formation is shown in Fig. 48. The overall thinning of the Horda Formation towards the south-east, east and north-east is also shown on the seismic sections in Figs 49 and 50 and on the log panel in Fig. 51.

Lithology. The Horda Formation is characterised by greenish grey to greyish green fissile mudstone. Subordinate limestone benches and thin layers of black mudstones occur at some levels in the formation. In many wells, particularly in the Central Graben, the lowermost 20-50 m of the Horda Formation consists of red-brown mudstones (Fig. 52). This lithology is apparently lacking in the eastern wells of the Danish sector.

Log characteristics. The Horda Formation is characterised by an overall stable gamma-ray and sonic log motif with a lower gamma-ray response than that displayed by the underlying Balder Formation and the overlying Lark Formation. In a few wells, the base of the Horda Formation shows relatively high gamma-ray values, which decrease to lower and more stable values over a short interval. The sonic readings decrease slightly upwards from the base to the top of the Horda Formation.

Boundaries. The base of the Horda Formation is placed at the change from the laminated, predominantly grey mudstones with interbedded sandy tuffs of the Balder Formation to the predominantly non-laminated, fissile, greenish grey or red-brown massive mudstones that form the basal part of the Horda Formation. The Balder-Horda boundary may be conformable or marked by a hiatus. The boundary is often difficult to pick on petrophysical logs. In basinal settings, Knox \& Holloway (1992) advocated placing the lower boundary of the Horda Formation at the base of a marked gamma-ray peak believed to represent a glaucony-rich condensed layer in the basal part of the Horda Formation. However, in many sections in the Danish sector there are two or more gamma-ray peaks in the Balder-Horda boundary interval. As the glaucony- rich layer has not been identified with certainty in the few cores taken across the boundary in the Danish sector, it is not possible to identify the key gamma-ray peak unambiguously. Therefore, it is suggested that the lower boundary of the Horda Formation is placed on the basis of the sonic log where a gradual decrease in values in the upper part of the Balder Formation is succeeded by relatively stable, but somewhat lower readings in the Horda Formation (Figs 46, 47). The upper boundary is at the base of the Lark Formation.

Subdivision. Knox \& Holloway (1992) suggested a threefold subdivision of the Horda Formation (H1-3), based on lithology and biostratigraphy. A threefold subdivision can also be seen on seismic sections in the Danish sector of the North Sea (Fig. 50). In some Central Graben wells, the subdivision may also be recognised on shifts in log patterns on both gamma-ray and sonic logs (Fig. 51). In these wells, subtle peaks separate the three units on the gamma-ray log and coincide with the top $\mathrm{H} 1$ and top $\mathrm{H} 2$ seismic markers. Based on analysis of cuttings samples, the subdivision apparently lacks lithological expression in the Danish sector. Knox \& Holloway (1992) noticed that the top of unit $\mathrm{H} 1$ is close to the $\mathrm{HO}$ of the dinoflagellate Eatonicysta ursulae, and that the top of unit $\mathrm{H} 2$ is close to the HO of the foraminifer Spiroplectammina spectabilis. This observation is supported by biostratigraphical data from the present study. A sandstone body within the Horda Formation has been encountered in the well Floki-1 on the Ringkøbing-Fyn High) in the Danish sector of the North Sea. This sandstone is defined herein as the new Hefring Member (see below).

Macro- and ichnofossils. The Horda Formation is moderately to intensely bioturbated. Ichnofossils comprise Chondrites ispp., Phycosiphon ispp. and Planolites ispp.

Microfossils and palynomorphs. In wells where the Horda Formation rests conformably on the Balder Formation, the dinoflagellate events HO Deflandrea oebisfeldensis and $\mathrm{HO}$ Dracodinium condylos occur in the lowermost part of the Horda Formation. Characteristic microfossil datums from the lowermost part of the Horda Formation are the HO of the planktonic foraminifer Subbotina ex gr. linaperta, which occurs abundantly, followed upwards by the almost coeval HOs of the benthic foraminifers Uvigerina batjesi, Turrilina brevispira and Gaudryina hiltermanni. A hiatus between the Horda and Balder Formations is indicated in wells in the northern and eastern part of the Danish sector by the absence of D. oebisfeldensis and D. condylos from the lower part of the Horda Formation. Central 


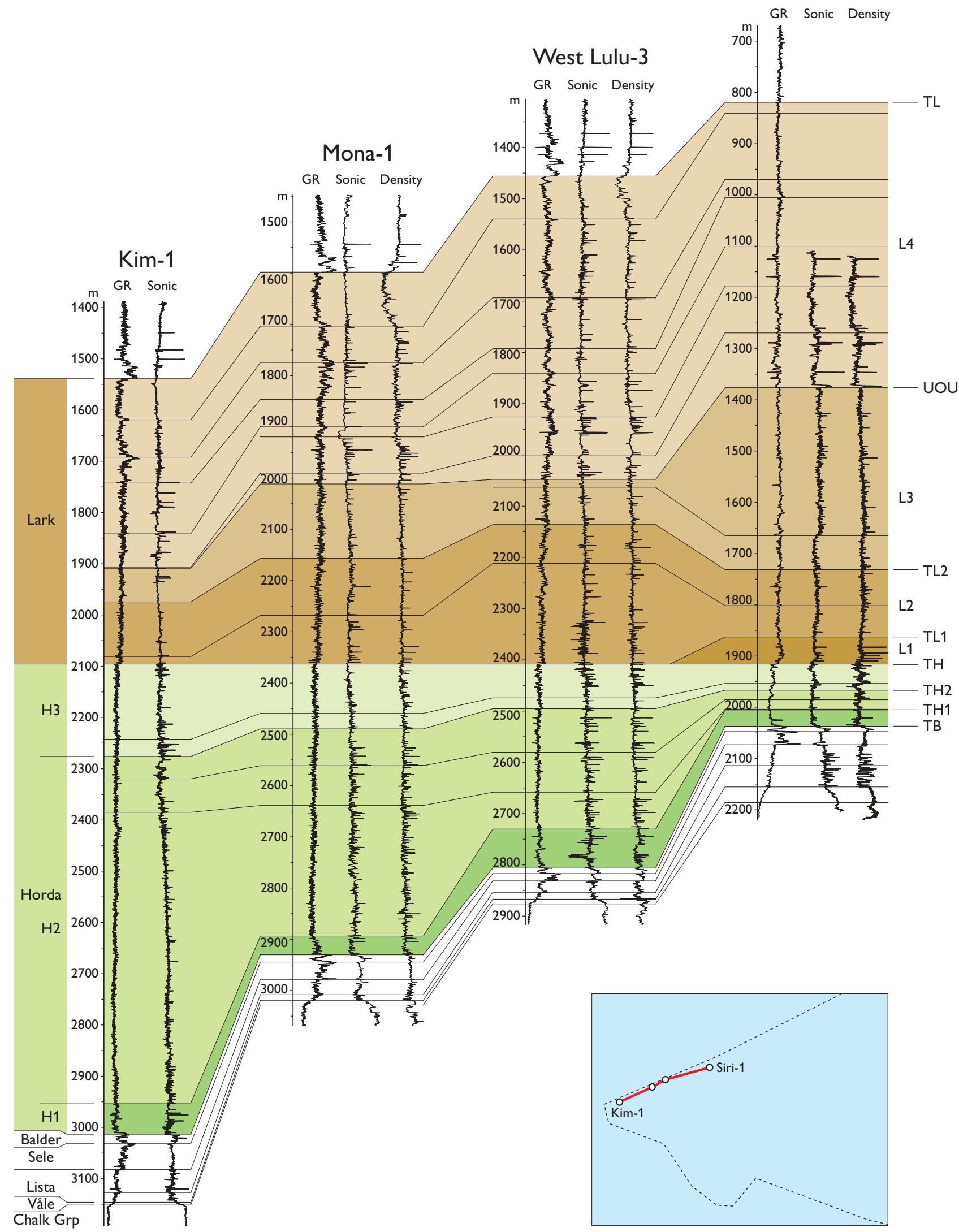


Graben wells contain the downhole succession of the dinoflagellate cyst events HO Areosphaeridium diktyoplokum, HO Areosphaeridium michoudii, HO Heteraulacacysta porosa and HO Cerebrocysta bartonensis from the top of the Horda Formation, indicating an age as young as earliest Rupelian (Fig. 5b). In wells to the north and east, the top of the Horda Formation seems to be slightly older since A. michoudii is recorded from the top of the formation, indicating a mid-Priabonian age (Fig. 5b). Significant dinoflagellate events from the middle to upper part of the Horda Formation are the succession of the HOs of Eatonicysta ursulae, Diphyes ficosoides and Phthanoperidinium clitbridium in the middle part of the formation, and the HOs of Diphyes colligerum and C. bartonensis in the upper part of the formation. In Central Graben wells, significant microfossil events in the lower part of the Horda Formation include the $\mathrm{HO}$ of abundant radiolaria of the genus Cenosphaera and the $\mathrm{HO}$ of the planktonic foraminifer Cyclammina amplectens. Key events in the middle and upper parts of the formation are the HOs of Pseudohastigerina spp. (planktonic foraminifers), Lenticulina gutticostata, Spiroplectammina amplectens and Planulina costata (benthic foraminifers). The top of the Horda Formation contains the HOs of Cibicidoides truncanus and Vaginulinopsis decorata.

Depositional environment. The lower part of the Horda Formation contains a microfauna that is significantly different from that of the underlying Balder Formation. The basal 5-40 m of the Horda Formation are characterised by a diverse fauna of both benthic and planktonic calcareous foraminifers together with agglutinated foraminifers. This indicates that the depositional setting was open marine, bathyal and with oxic bottom conditions.

The upper part of the Horda Formation is characterised by an abundant and diverse agglutinated foraminifer fauna. Calcareous foraminifers are very sparse or absent in this interval. The assemblage of Rhabdammina discreta, Haplophragmoides spp., Recurvoides spp. and Usbekistania charoides indicate that the upper part of the Horda Formation was deposited at upper bathyal depths with dysoxic bottom conditions. Radiolaria occur commonly in several narrow intervals, the lowest of which is slightly

\section{Facing page:}

Fig. 51. SW-NE-trending log panel showing eastward thinning of the Horda Formation. The figure also shows the variation in architecture and distribution of the Horda units $\mathbf{H 1}-\mathbf{H} 3$ and Lark units L14 between the Central Graben (Kim-1, Mona-1 and West Lulu-3) and the Ringkøbing-Fyn High (Siri-1). Seismic ties: TL1, Top L1; TH2, Top H2; TH1, Top H1; other abbreviations as in Fig. 49.

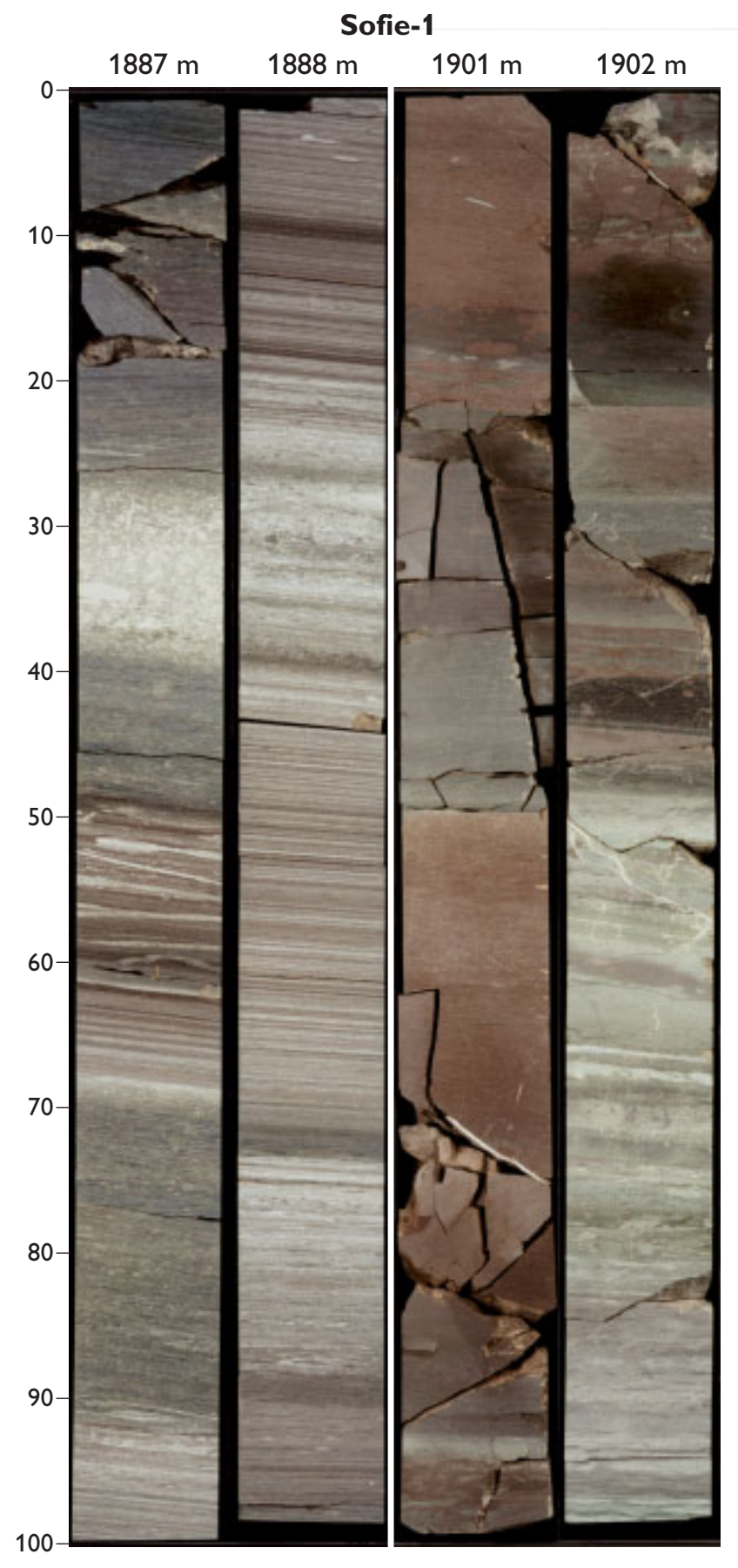

Fig. 52. Core photographs showing red to reddish grey mudstones of the lowermost part of the Horda Formation in the Sofie-1 well. Depths are core depths.

above the top of the lower, oxic part of the formation. The occasional influxes of radiolaria recorded throughout the upper part of the formation suggest that deeper marine conditions prevailed periodically.

The palynofacies of the Horda Formation is characterised by a rich and dominant dinoflagellate assemblage with dispersed terrestrial matter (phytoclasts, spores and pol- 


\section{Floki-1}

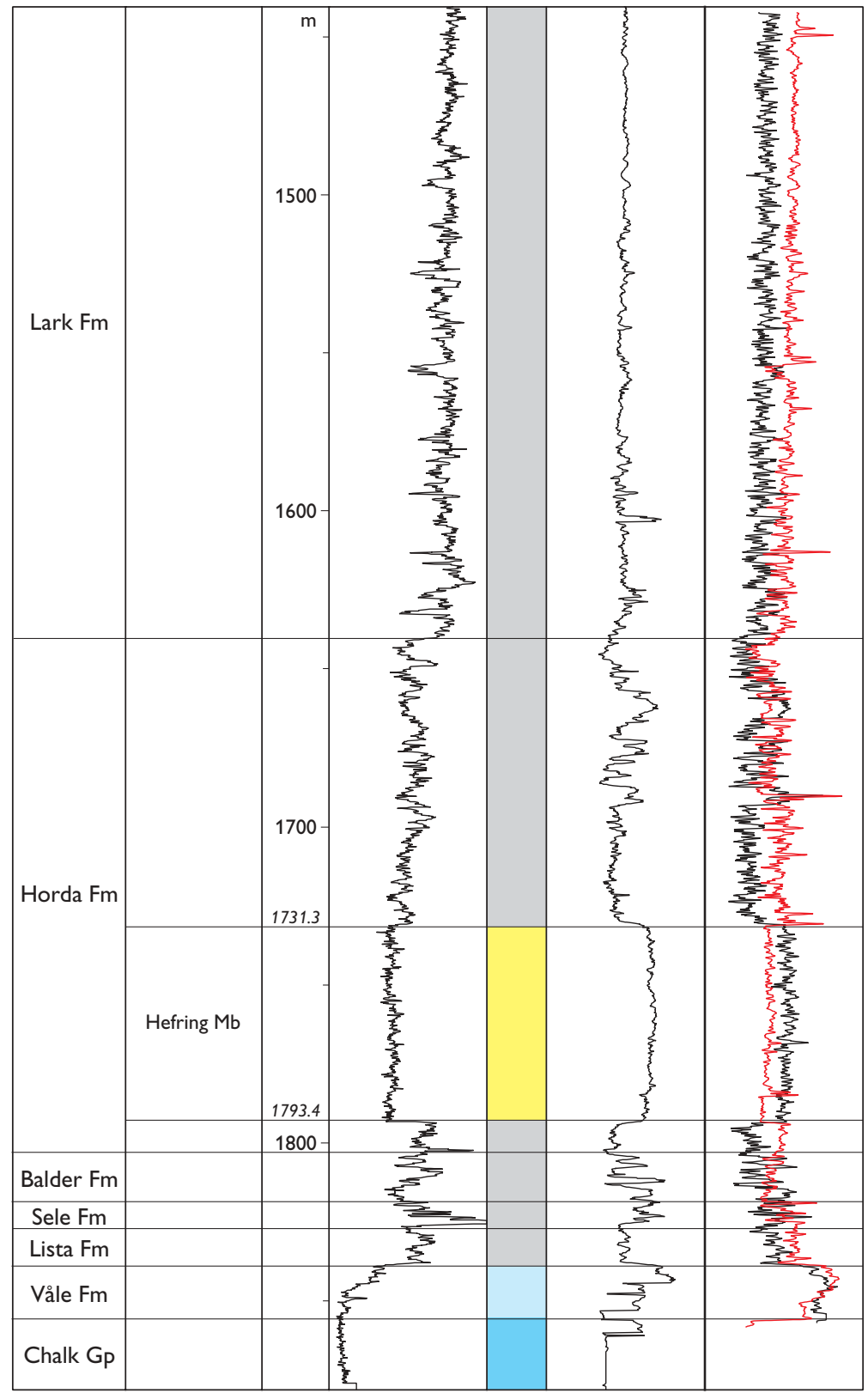

Fig. 53. Floki-1, type well for the Hefring Member.

len) as a minor component, indicating an open marine environment with only limited influx from surrounding terrestrial areas.

Age. In the Central Graben, where the Horda Formation is most complete, the formation spans from the middle Ypresian (Early Eocene) at its base to earliest Rupelian (earliest Oligocene) at its top. In wells to the east and north, the top is as old as middle Priabonian (see also biostratigraphic section above). This indicates that the top of the Horda Formation is diachronous, younging in a southwesterly direction. This is possibly due to increased ero- sion or longer intervals of non-deposition towards the north-east in the basin, or both.

Correlation. The Horda Formation can be correlated with the onshore Danish succession of the Røsnæs Clay Formation, the Lillebælt Clay Formation and the Søvind Marl Formation (Heilmann-Clausen et al. 1985), and the Viborg Formation (Christensen \& Ulleberg 1973).

The red-brown mudstones near the base of the Horda Formation in the central North Sea can be correlated lithologically with the Røsnæs Clay Formation and the lower part of the Lillebælt Clay Formation. 
The lower part of the overlying main body of greenish and greyish mudstones in the offshore succession can be correlated with the coeval and lithologically similar upper part of the Lillebælt Clay Formation. The upper part of the Horda Formation can be correlated with the Søvind Marl Formation, which consists of grey marls. The highest part of the Horda Formation, only observed in Central Graben wells, may be correlated with the Viborg Formation on biostratigraphic evidence.

\section{Hefring Member}

new member

History. The Hefring Member consists of sandstone deposits within the Horda Formation. These sandstones have not previously been recognised as a separate unit in the Danish sector.

Derivation of name. After the goddess Hefring.

Type well. Danish sector well Floki-1, 1793.4-1731.3 m MDRT (Fig. 53).

Distribution and thickness. The Hefring Member is only known from the Floki-1 well located in the northern part of the Danish sector. As the unit currently cannot be identified on seismic sections, its further distribution is unknown. In the Floki-1 well, the member is $62 \mathrm{~m}$ thick.

Lithology. The Hefring Member consists of greenish grey, fine-grained, immature sandstones with glaucony grains.

Logcharacteristics. The Hefring Member is characterised by a conspicuous blockysignature on the gamma-ray, sonicand density logs (Fig. 53). Gamma-ray responses are lower than those of the enveloping Horda Formation mudstones. The Hefring Member can also be recognised from a combination of the density and neutron logs as the presence of pure sandstones results in a 'cross-over' of the two log curves (Fig. 53).

Boundaries. The boundaries with the mudstones of the Horda Formation are sharp and characterised by prominent shifts on the gamma-ray and sonic logs (Fig. 53).

Depositional environment. No cores have been taken in the Hefring Member, but the sandstones were probably deposited from concentrated gravity flows, based on log similarity with the other fine-grained sandstone bodies in the nearby Siri Canyon.
Age. Lutetian (Middle Eocene) based on the age of the associated Horda Formation mudstones.

Correlation. Based on biostratigraphic data, the Hefring Member may be contemporaneous in part with the Lillebælt Clay Formation onshore Denmark, with the lower part of the Grid Sandstone Member (Knox \& Holloway 1992) in the Viking Graben and with the upper part of the Tay Sandstone Member (Knox \& Holloway 1992) in the northern part of the Central Graben.

\section{Westray Group}

The Westray Group is the upper of the two groups established by Knox \& Holloway (1992) to replace the Hordaland Group of Deegan \& Scull (1977; Fig. 3). In the central North Sea and in the Danish sector of the North Sea, the Westray Group is represented by the Lark Formation.

\section{Lark Formation}

History. The Lark Formation was established by Knox \& Holloway (1992) for the brownish grey mudstone-dominated lithofacies of the Westray Group that overlies the more variable association of red and green-grey mudstones, silty mudstones and sandstones of the Horda Formation and underlies the grey, sandy and shelly mudstones, siltstones and sandstones of the Nordland Group of Deegan \& Scull (1977; Fig. 3). The Lark Formation is also recognised in the Danish sector although its lithology is more variable than that given in the original description.

Type well. British sector well 21/10-4, 1867-1217 m MDKB.

Danish reference wells. Mona-1, 2363.5-1598.3 m MDKB (Fig. 46); Siri-1, 1916.5-819.3 m MDKB (Fig. 54).

Distribution and thickness. The Lark Formation extends over the central and northern North Sea and is probably present in the entire Danish sector of the North Sea. Its depocentre is in the central and northern part of the Danish sector, along the eastern boundary of the Danish Central Graben, where it reaches a thickness of $1194 \mathrm{~m}$ in the Siri-3 well. The Lark Formation thins west to a thickness of $389 \mathrm{~m}$ in the Tordenskjold- 1 well in the Central Graben, and east to a thickness of $240 \mathrm{~m}$ in the S-1 well on the Ringkøbing-Fyn High (Fig. 55). 
Siri-1

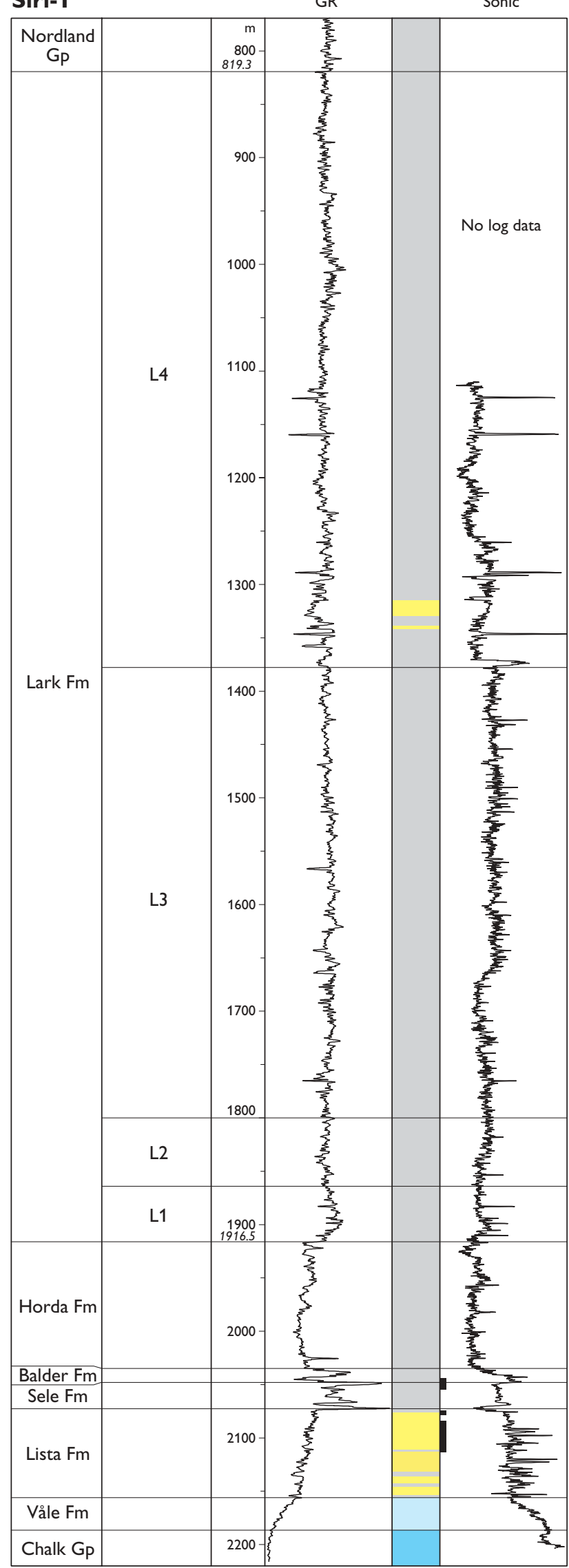

Lithology. The lower Lark Formation (L1-3, see below) is dominated by dark, greenish grey, non-fissile mudstones in most wells; in some wells subordinate intervals of brownish grey mudstones are also present. Thin layers of white or reddish brown carbonate are also recorded in the upper levels of the lower Lark Formation.

The upper Lark Formation (L4, see below) is dominated by pale to dark brownish grey mudstones with subordinate intervals of greenish grey mudstones in its lower levels. The uppermost 50-100 m of the formation consist of yellowish grey to light brown mudstones. In eastern and northern parts of the Danish sector, discrete sandstone interbeds and thin sandstone stringers occur throughout the formation.

Log characteristics. The lower part of the Lark Formation is characterised by an overall stable gamma-ray log signature, whereas the upper part of the formation has a more unstable signature (Figs 46, 54). This change in gammaray log signature coincides approximately with the change from lithologies dominated by greenish grey mudstones to lithologies dominated by dark to light brownish grey mudstones at the base of unit L4 (see below).

Boundaries. The base of the Lark Formation is marked by a change from fissile, greenish grey mudstones of the Horda Formation to non-fissile, greenish grey mudstones of the Lark Formation. This change in lithology coincides with an abrupt increase in gamma-ray values to a consistently higher level than that displayed by the Horda Formation (Figs 46, 51, 54). Wells in the eastern part of the Danish Central Graben and on the Ringkøbing-Fyn High show a conspicuous log break on the gamma-ray log at the formation boundary, whereas the log break is less pronounced in wells from the central and western parts of the Danish Central Graben (Fig. 51). Although the actual increase in gamma-ray response may be limited in the latter wells, the offset is usually sharp and well defined. On the sonic $\log$, the boundary between the Horda Formation and the Lark Formation is characterised by a transition from a stable sonic signature to one characterised by numerous fluctuations.

The Lark Formation is overlain by the undifferentiated Nordland Group of Deegan \& Scull (1977). Over most of the area, the boundary seems conformable and is represented by a change from yellowish grey and light brown mudstones to medium to dark grey mudstones characte-

Fig. 54. Siri-1, Danish reference well for the Lark Formation. The units $\mathbf{L} \mathbf{1} \mathbf{4}$ are all present in this well. Black bars show cored sections. 
Fig. 55. Isochore map of the Lark Formation in the study area. The positions of the two Danish reference wells, Mona-1 and Siri-1, are indicated in the figure. The map also shows the distribution of the sandstones of the Dufa and Freja Members and the location of their type and reference wells, Inez-1 and F-1, and Francisca-1 and Frida-1, respectively.

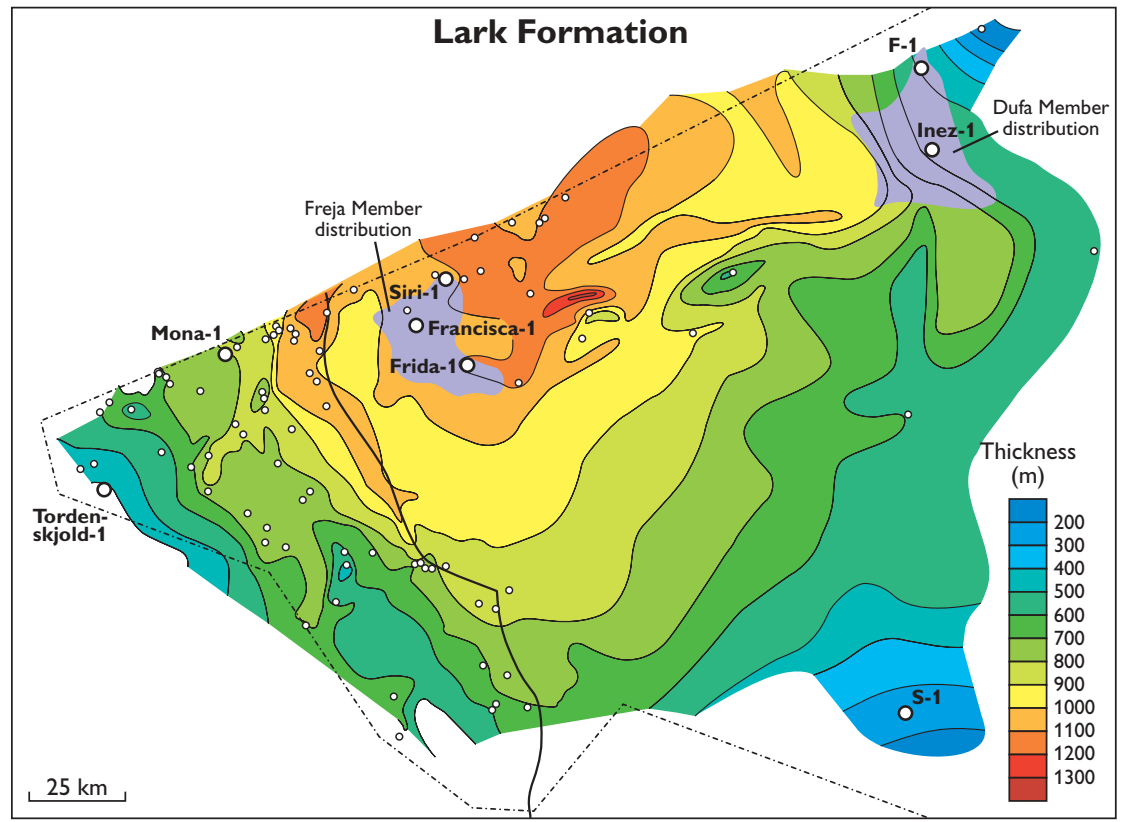

rised by intervals with shell-hash and coarse-grained sands. This boundary is marked by a conspicuous gamma-ray peak at the base of a 20-40 m thick interval with elevated gamma-ray values in the lowermost Nordland Group (Figs $46,51)$. This interval is further characterised by a marked double peak on the gamma-ray log.

In the north-eastern parts of the Danish sector (Nini-1, Vanessa-1, Cecilie-1 and Siri-1; Figs 1, 51, 54), sediments of the Nordland Group rest unconformably on the Lark Formation. In this area the uppermost Lark Formation and the lowermost Nordland Group are missing, probably due to erosion and/or non-deposition. The distinct gamma-ray peak that marks the top of the Lark Formation as well as the double gamma-ray peak in the lowermost Nordland Group are lacking in these wells, and therefore the top of the Lark Formation is more difficult to identify on petrophysical logs.

Subdivision. The Lark Formation can be subdivided into four major mudstone packages, L1-L4, based on seismic and $\log$ evidence (Figs 46, 49, 51, 54, 56; Plates 1-5). These units are described below; isochore maps of the units are shown in Fig. 57a-d.

\section{L1 (Figs 51, 56a, b, 57a; Plates 1, 4, 5)}

This unit has been recognised in the north-eastern part of the Danish sector only (Fig. 57a). It is bounded beneath by the TH marker and above by the TL1 marker (Fig. 56a, b). It is characterised by downlapping reflectors and represents a south-westwards prograding mudstone succession. On the gamma-ray log, the L1 unit is characterised by a relatively high and relatively stable response. In most wells, it shows a weakly concave pattern, going from a relatively high gamma-ray response at its base, over a gamma-ray low halfway through the unit to a level close to starting level at the top of the unit (e.g. Ida-1, Inez-1, K-1, F-1 and Sandra-1; Plates 1, 4, 5). In the Siri-1 and Siri-3 wells, near the south-western limit of the L1 unit, the gamma-ray log motif instead appears slightly convex (Figs 51, 54; Plates 1, 4). The L1 unit consists predominantly of greenish grey mudstones but also includes yellowish brown and dark grey mudstones.

\section{L2 (Figs 46, 51, 56a, b, 57b; Plates 1-5)}

The unit is recognised over the entire study area. On the gamma-ray and sonic logs the unit is characterised by a stable log signature. The gamma-ray log shows two to three slightly concave patterns with signatures similar to that of the L1 unit (Fig. 51; Plates 1, 4). The lithology is characterised by dark beige-grey to greenish grey mudstones, greenish colours becoming dominant towards the top of the unit.

\section{L3 (Figs 46, 51, 56a, b, 57c; Plates 1-5)}

This unit is encountered in the northern and eastern parts of the Danish sector, east of the Central Graben (Fig. 57c) but is not recognised on logs or seismic sections in the Central Graben area. It is characterised by stable gamma-ray and sonic $\log$ signatures (Figs 46, 51; Plates 1-4). The unit consists almost invariably of dark, greenish grey mudstones.

\section{L4 (Figs 46, 51, 56a, b, 57d; Plates 1-5)}

The unit is recognised over the entire study area (Fig. 57d). The interval is characterised by a slightly more unstable gam- 

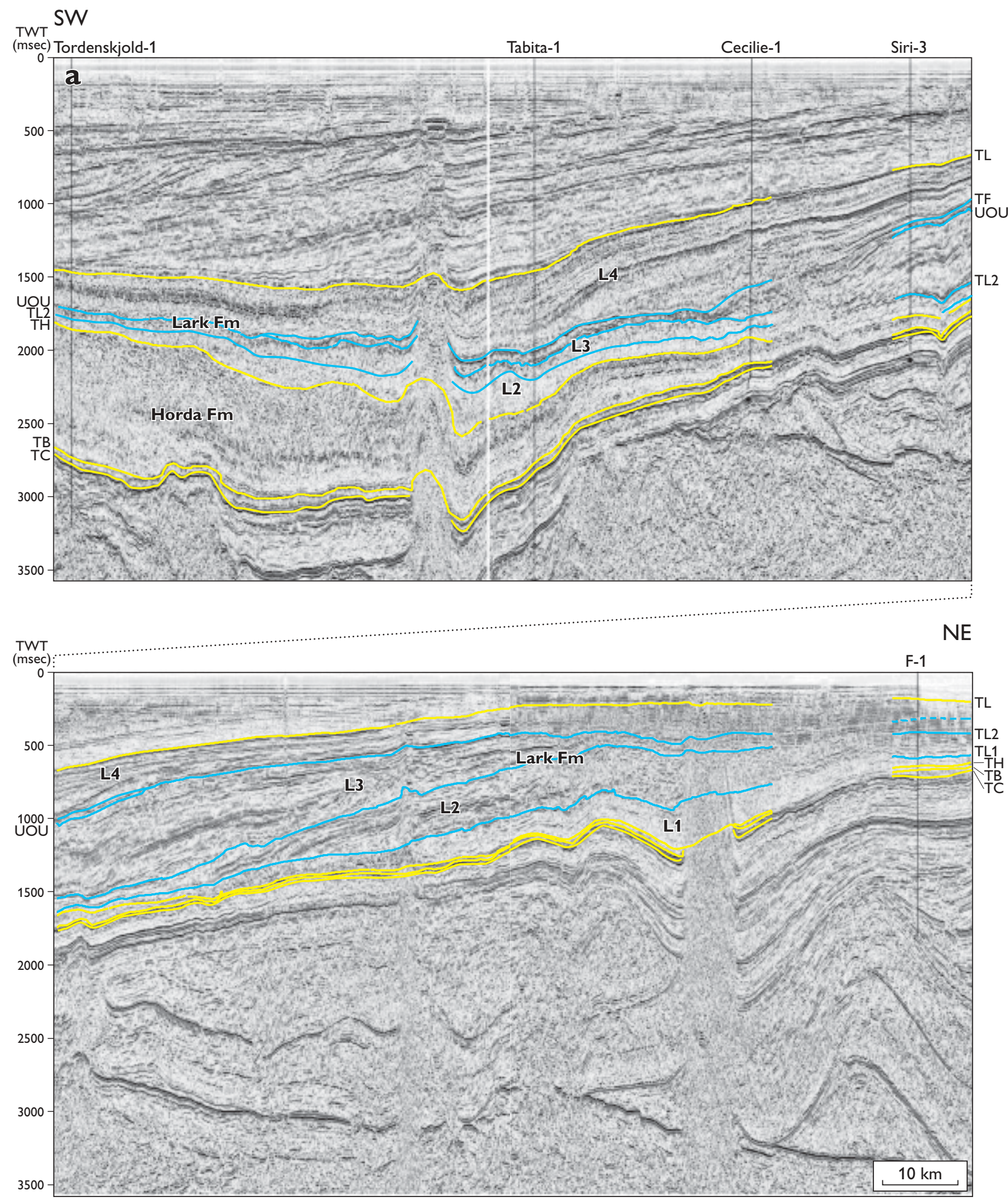

Fig. 56. a: SW-NE-trending seismic section (RTD81-RE94-22A) showing the complex architecture of the Lark Formation and its subdivision into L1-4 units. The vertical white line indicates change in section direction. The locations of the two seismic sections are shown on Fig. 1; abbreviations as in Figs 49 and 51. 
NW

TWT Nolde-1

(msec) Nini-2 D-1

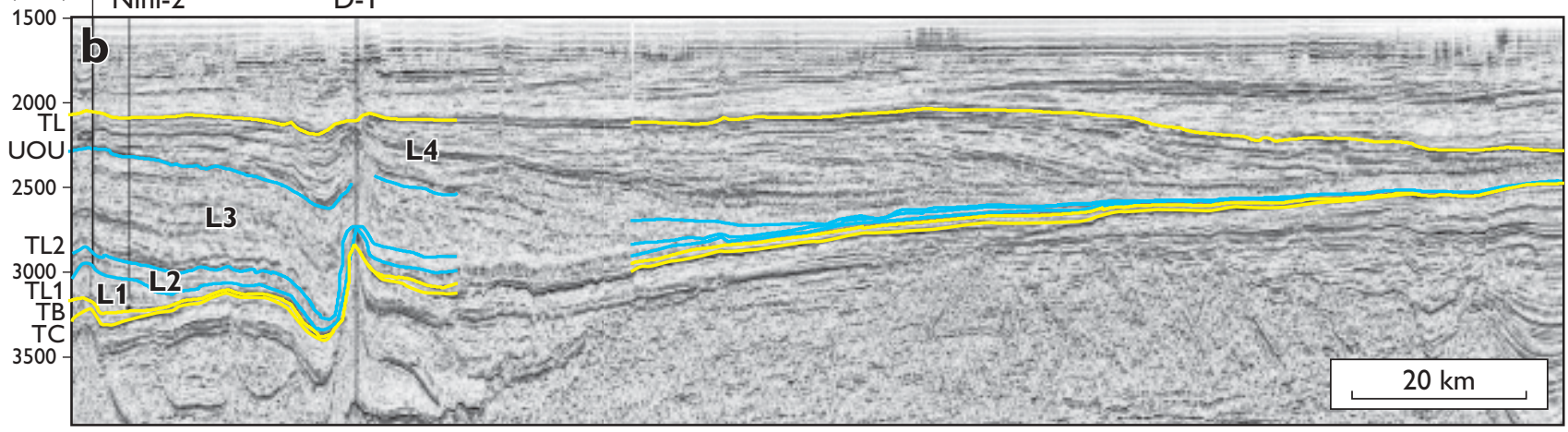

Fig. 56. b: NW-SE-trending seismic section (RTD81-RE94-14A) showing subdivision of the Lark Formation and marked thinning of this formation towards the south-east. The locations of the two seismic sections are shown on Fig. 1; abbreviations as in Figs 49 and 51.
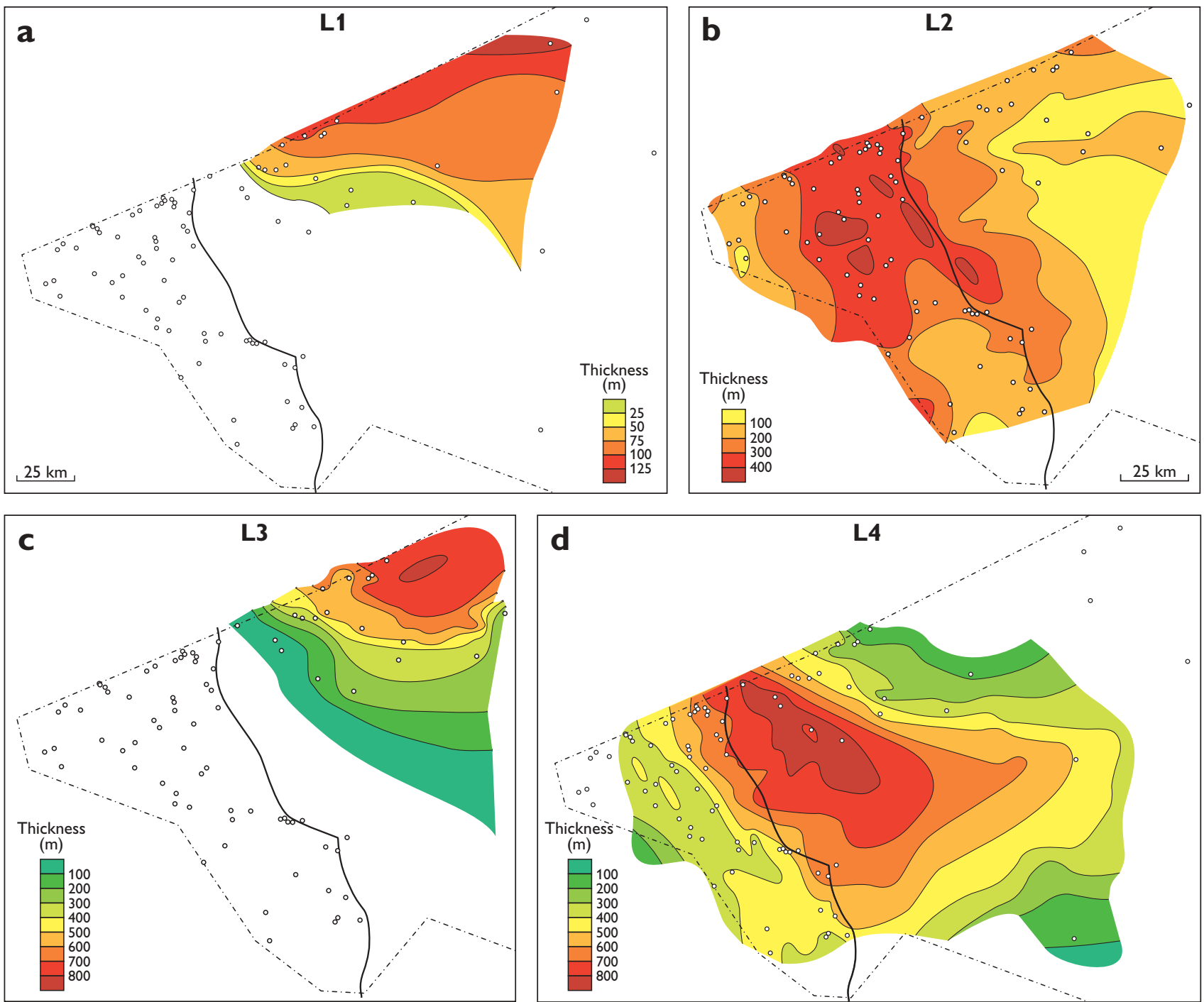

Fig. 57. Isochore maps of Lark Formation subunits. a: L1. b: L2. c: L3. d: L4. $\mathbf{a}$ and $\mathbf{d}$ are at the same scale, $\mathbf{b}$ and $\mathbf{c}$ are at the same scale. 
ma-ray and sonic log signature than that of the underlying units (Figs 46, 51; Plates 1-5). It is dominated by brown to yellowish brown mudstones, but in some wells an interval of greenish grey mudstones occurs in its lower part. In wells to the east and north, thin sandstones are interbedded with the mudstones and become more frequent towards the top of the unit.

Two thick sandstone units occur in the Lark Formation on the Ringkøbing-Fyn High and are described here as two new members (Dufa and Freja Members).

Macro- and ichnofossils. Only observed in cores taken in the Freja Member (see below).

Microfossils and palynomorphs. Farthest to the north and east the basal part of the formation includes the downhole succession of HO Areosphaeridium diktyoplokum and HO A. michoudii indicating a late Priabonian (Late Eocene) age for the base of the formation in this area. In the Central Graben area, the base of the Lark Formation is significantly younger. Here it contains an event succession characteristic of the middle and lower Rupelian (Lower Oligocene) Stage (HOs of Phthanoperidinium amoenum, Achilleodinium biformoides and Phthanoperidinium comatum).

The top of the Lark Formation is bracketed by a number of conspicuous biostratigraphic events: the uppermost part contains the HOs of the benthic foraminifers Asterigerina staeschei and Elphidium inflatum followed downhole by the $\mathrm{HO}$ of Uvigerina tenuipustulata. Dinoflagellate events near the top of the Lark Formation include the HOs of Apteodinium spiridoides and Cousteaudinium aubryae. The lowermost part of the overlying Nordland Group contains the HOs of the calcareous microfossils Bolboforma clodiusi, Bolboforma spiralis and Bolboforma metzmacheri, the $\mathrm{HO}$ of the benthic foraminifer Bulimina elongate, and the $\mathrm{HO}$ of the dinoflagellate cyst Cannosphaeropsis passio. A large number of $\mathrm{HOs}$ characterise the Lark Formation; key events are listed in Fig. 5c.

Depositional environment. The $\mathrm{L} 1$ unit is characterised by abundant agglutinated foraminifers dominated by Rhabdammina discreta and similar tubular taxa, together with Haplophragmoides spp. and Recurvoides spp. The microfaunal assemblage indicates that the unit was predominantly deposited in an open marine, dysoxic palaeoenvironment at upper bathyal depths.

The L2 unit and most of the L3 unit are characterised by an increasing abundance and diversity of calcareous benthic and planktonic foraminifers. The relative propor- tions of agglutinated, calcareous planktonic and benthic foraminifers vary considerably from well to well, indicating pronounced lateral changes in the depositional environment. The calcareous plankton/benthos ratio is usually low, indicating a neritic setting for most of the succession, but in a few restricted intervals it may reach $1: 2$ or even 1:1 indicating an outer neritic setting. Thus, the foraminifer assemblage indicates an open marine, neritic to outer neritic setting with well-oxygenated bottom conditions for the lower to middle part of the Lark Formation.

The microfossil assemblage in the uppermost part of the L3 unit as well as the L4 unit is dominated by calcareous benthic foraminifers, and agglutinated foraminifers are generally rare. Epifaunal and shallow infaunal foraminifers are more common than deep infaunal taxa, indicating oxic bottom conditions during this interval. In gene$\mathrm{ral}$, the microfaunal assemblage in this part of the Lark Formation suggests that it was deposited in a neritic, probably middle neritic, palaeoenvironment over most of the study area.

The palynofacies assemblage in the Lark Formation is characterised by a rich dinoflagellate assemblage and abundant dispersed terrestrial matter (phytoclasts, spores and pollen), indicating an open marine environment with considerable influx from nearby land areas. Stratigraphic variations in the relative abundance of terrestrial palynomorphs in the Lark Formation suggest successive pulses of progradation and backstepping of the palaeocoastline.

Age. The Lark Formation is of Priabonian to Serravallian (Late Eocene to Middle Miocene) age with Eocene sediments being present in the L1 unit only. The L1 unit is Priabonian to early Rupelian (Early Oligocene) in age, the base of the unit being oldest farthest to the north and east and younging towards the south and west. The age of the L2 unit is Rupelian; the L3 unit is Rupelian in age in its lower part and Chattian (Late Oligocene) in its upper part. The Rupelian-Chattian boundary is located in the lower part of the unit. The Chattian-Aquitanian (OligoceneMiocene) boundary is located just above the top of the L3 unit. In some wells, a hiatus is indicated at this level by the clustering of HOs. The Chattian-Aquitanian, Aquitanian-Burdigalian, Burdigalian-Langhian and Langhian-Serravallian stage boundaries are all located in the L4 unit. The uppermost part of the Lark Formation is of midSerravallian age.

Correlation. Based on biostratigraphic correlation, the lowermost L1 unit is probably largely coeval with the $\mathrm{Vi-}$ borg Formation onshore Denmark, and with Sequence 4.1 of Michelsen et al. (1998). The L2 unit may be corre- 


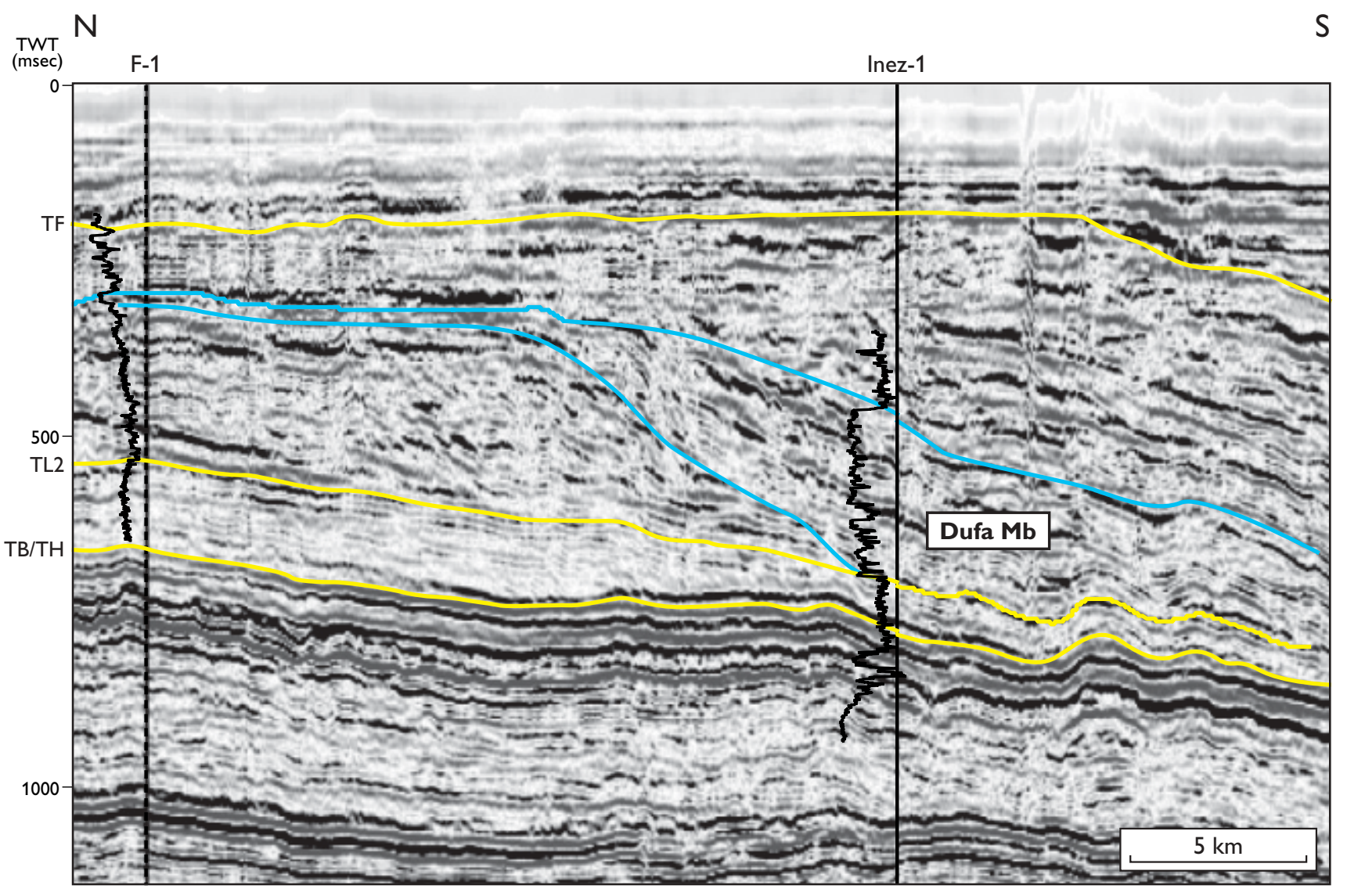

Fig. 58. N-S-trending composite seismic section (RTD81-RE94-45/RTD81-RE94-09). Blue-coloured lines indicate the outline of the Dufa Member. The gamma-ray logs from the Inez-1 and F-1 wells are inserted (see Figs 55 and 59 for depth-converted gamma-ray logs for the two wells). The Horda Formation is thin in this area and the Top Horda reflector (TH) is therefore indistinguishable from the Top Balder reflector (TB). The location of the seismic section is shown in Fig. 1; abbreviations as in Fig. 49.

lated with the Linde Clay onshore Denmark (informal mudstone unit described by Heilmann-Clausen 1995). Intervals in the L3 unit may be correlated with the Branden Clay (Ravn 1906) onshore Denmark, based on lithological similarities and biostratigraphy. Intervals in the Lark Formation around the L3-L4 boundary (around the Chattian-Aquitanian boundary) may be correlated with the two lowermost, clay-rich units of the onshore Vejle Fjord Formation (the Brejning Clay and VejleFjord Clay of Larsen $\&$ Dinesen 1959). The uppermost part of the Lark Formation possibly correlates with the onshore Arnum Formation (Sorgenfrei 1958) and the Hodde Formation onshore Denmark (Rasmussen 1961), based on biostratigraphy.

\section{Dufa Member}

new member

History. The Dufa Member comprises a thick sandstone- dominated unit that occurs within unit L3 of the Lark Formation in the northern and eastern part of the Danish sector of the North Sea. The unit has not been previously described.

Derivation of name. After the goddess Dufa.

Type well. Danish sector well Inez-1, 697.1-485.5 m MDKB (Figs 41, 58; Plates 1, 5).

Reference well. Danish sector well F-1, 337.5-324.3 m MDKB (Figs 58, 59; Plate 5).

Distribution and thickness. The Dufa Member is present in the north-eastern part of the Danish sector of the North Sea (Fig. 55). In its type well, the Dufa Member is $210 \mathrm{~m}$ thick and consists of three major sandstone units with thicknesses 30-120 m (Fig. 41). The sandstone units are separated by mudstone intervals up to $20 \mathrm{~m}$ thick. Towards the north, in the F-1 well, the lower sandstone units are 


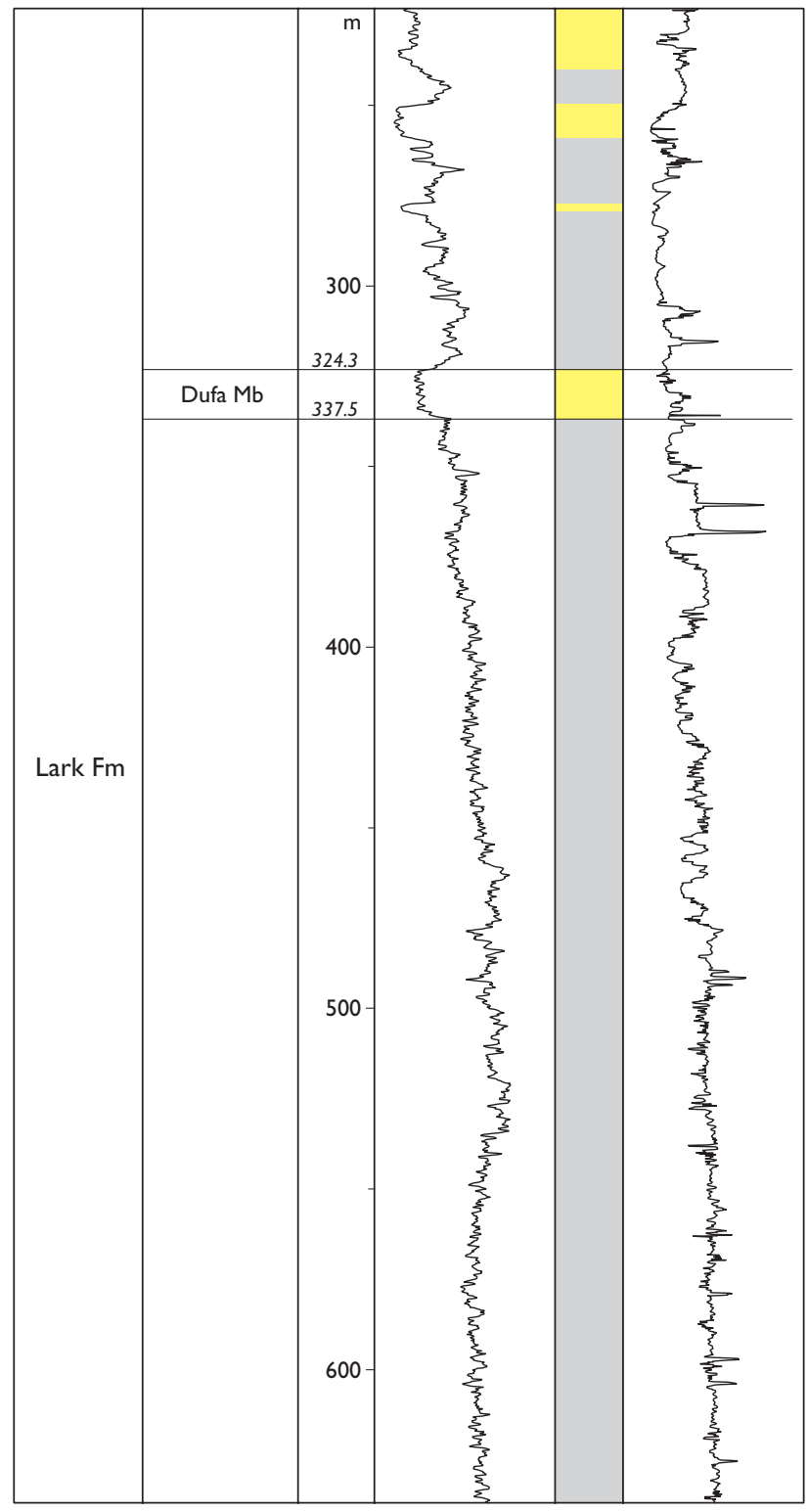

Fig. 59. F-1, reference well for the Dufa Member.

missing (Figs 58, 59). The Dufa Member is absent in wells west of F-1.

Lithology. The lower sandstone units predominantly consist of coarsening-upwards successions of very fine-grained to fine-grained, greenish brown, muddy sandstones. The upper sandstone unit fines upwards and consists of medium- to coarse-grained, quartzitic, relatively pure sand with intervals rich in glaucony. Lignite has been observed in cuttings samples.

Log characteristics. The member is characterised by an overall blocky signature on the gamma-ray log. In the type

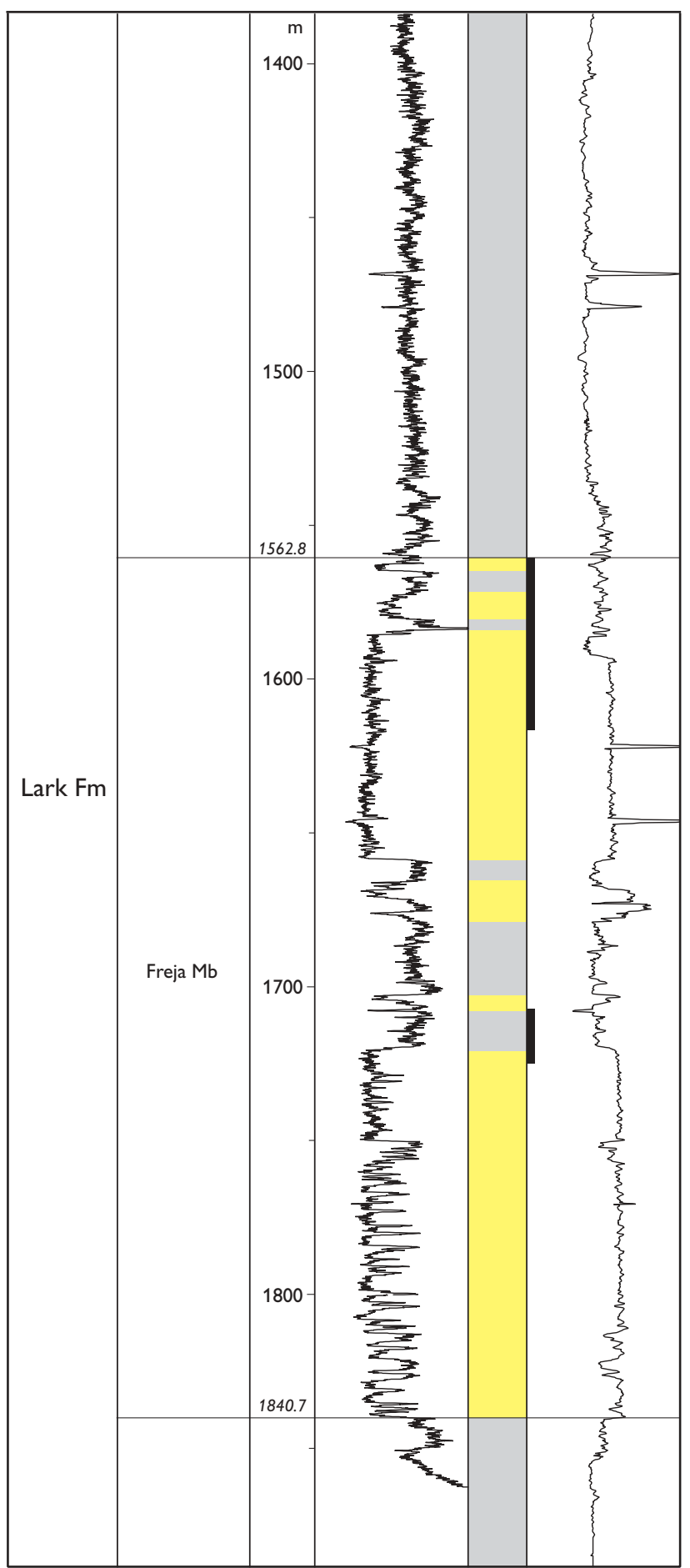

Fig. 60. Francisca-1, type well for the Freja Member. Black bars show cored sections.

well, the lower sandstone intervals of the Dufa Member show the presence of a number of 5-10 m thick sandstone packets showing blocky, decreasing-upwards gamma-ray log signatures suggesting coarsening-upwards sand bodies. These sandstones are separated by intervals of 
mudstones with higher gamma-ray response. The upper unit is characterised by an overall blocky signature with minor gamma-ray peaks and trends suggesting a number of fining-upwards intervals, $10-20 \mathrm{~m}$ thick, and a few coarsening-upwards intervals, 5-10 m thick (Fig. 41).

Boundaries. The upper and lower boundaries of the member with the mudstones of the Lark Formation are sharp and characterised by prominent shifts on the gamma-ray $\log$ (Figs 41, 59).

Depositional environment. Judging from seismic evidence, the Dufa Member is positioned partly on the offlap break, partly seaward of it (Fig. 58). Based on this palaeosetting and the presence of lignite in cuttings samples, the Dufa Member sandstones are interpreted to represent deltaic, shallow-marine sediments, probably deposited in pulses during an overall relative sea-level low.

Age. Rupelian, based on the age of the enveloping mudstones.

Correlation. There are no Danish onshore correlatives to the Dufa Member. The correlation with the Norwegian offshore successions is currently uncertain.

\section{Freja Member}

new member

History. The Freja Member is a conspicuous sandstonedominated unit that occurs within the upper levels (L4) of the Lark Formation in the northern and central parts of the Danish sector of the North Sea. The unit has not previously been described.

Derivation of name. After the goddess Freja.

Type well. Danish sector well Francisca-1, 1840.7-1562.8 m MDRT (Figs 60, 61).

Reference well. Danish sector well Frida-1, 1623.5-1487.7 m MDRT (Fig. 62; Plate 4).

Distribution and thickness. The Freja Member is present in the northern and central parts of the Danish sector of the North Sea (Fig. 55). In its type well, the Freja Member spans a stratigraphic interval of $c .280 \mathrm{~m}$ and includes major sandstone units separated by subordinate intervals of mudstones (Fig. 60). In the Cecilie-1 well, the member is $c .150 \mathrm{~m}$ thick whereas in the Frida-1 well the member attains c. $130 \mathrm{~m}$ (Fig. 62).

Lithology. In its type well, the lower half of the Freja Member consists of very fine-grained to fine-grained quarzitic sandstones with many thin mudstone interbeds. The member becomes less muddy in the upper third of this interval. The upper third of the Freja Member consists largely of relatively pure quarzitic, very fine-grained sandstones with mudstone interbeds becoming frequent towards the top (Fig. 60). Between these two major sandstone units is a c. $60 \mathrm{~m}$ thick interval dominated by mudstones but with carbonate-cemented, sandstone-dominated packets in its upper part.

Log characteristics. The Freja Member has an overall blocky gamma-ray log signature. In the type well, its lowermost part (1840.7-1750 m) can be split into a number of smaller units with blocky or increasing-upwards gamma-ray log signatures separated by gamma-ray peaks. In comparison, the overlying sandstones $(1750-1720 \mathrm{~m})$ display a more stable, low gamma-ray log pattern with few gamma-ray $\log$ spikes (Fig. 60). The mudstone-dominated interval $(1720-1660 \mathrm{~m})$ separating the two sandstone-dominated units in the type well generally shows high gamma-ray values: Thin calcite-cemented sandstone packets are intercalated with the mudstones in this interval (e.g. 1680$1670 \mathrm{~m}$ ) and show decreasing-upwards gamma-ray values.

Boundaries. The lower boundary of the Freja Member with the Lark Formation mudstones is sharp and characterised by prominent shifts on the gamma-ray and sonic logs. In the type well, where the upper levels of the Freja Member are characterised by interbedded mudstones and sandstones, the upper boundary of the member is less prominent. In this well, it is placed at the top of the uppermost discrete sandstone bed, at $1562.8 \mathrm{~m}$ (Fig. 60).

Macro- and ichnofossils. Intervals with shell debris have been observed in core sections of the Freja Member in the Francisca-1 well. Ichnofossil genera from the Freja Member comprise Chondrites ispp., Phycosiphon ispp., Planolites ispp., Terebellina ispp., Thalassinoides ispp. and Zoophycos ispp.

Depositional environment. The Freja Member represents stacked successions of thick- and thin-bedded turbidite sands deposited in submarine channels and proximal levee environments (Figs 60, 62). The upper parts of the turbidite successions show transitions from normally graded turbidites, deposited in slightly more distal levee environ- 


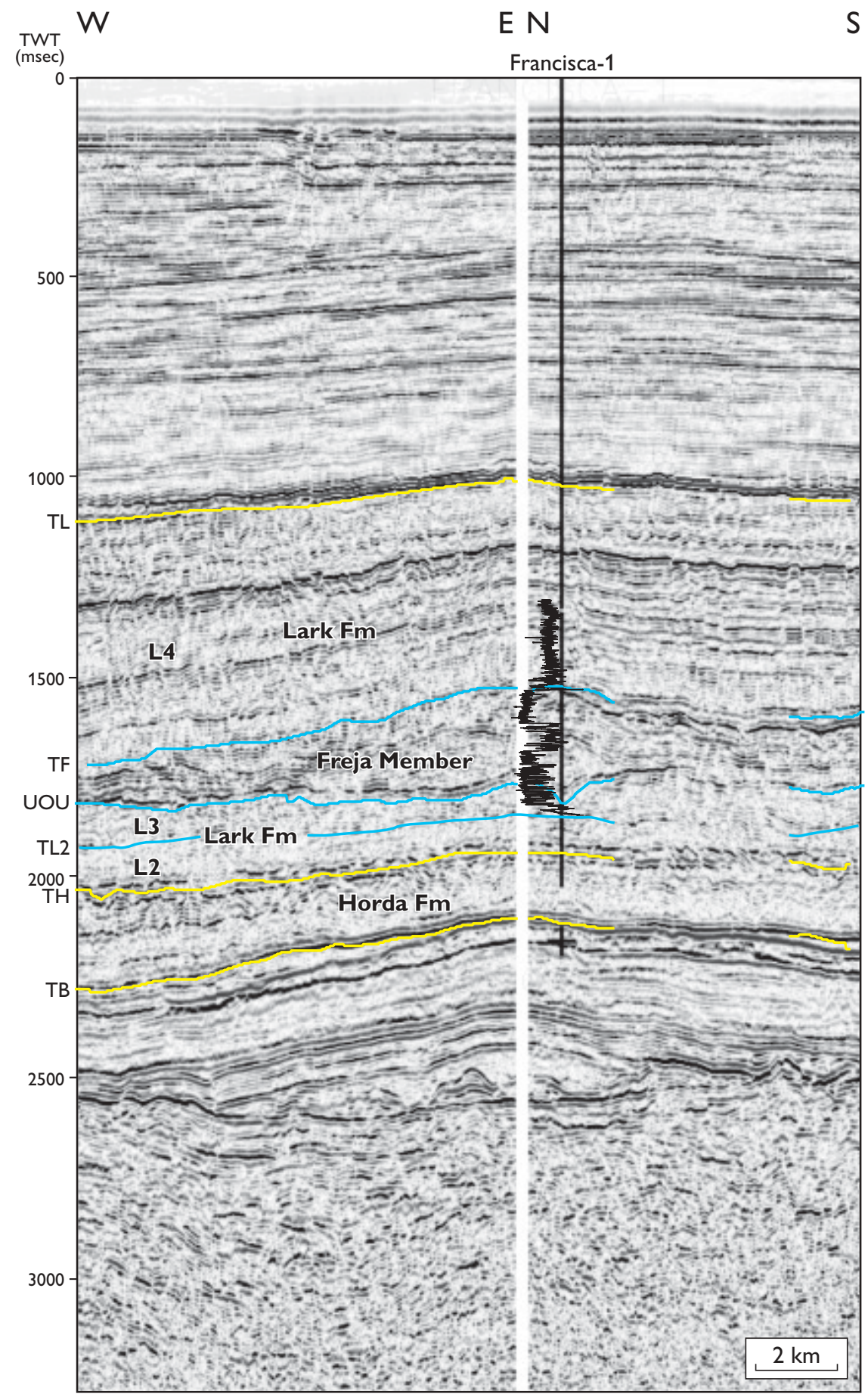

Fig. 61. Composite seismic section (DK1-5623A RE94/DK1-0448B RE94) with the Freja Member indicated between the reflectors UOU and TF. The gamma-ray log from the Francisca-1 well is indicated on the figure (see Fig. 60 for depth-converted gamma-ray log). The vertical white bar indicates where the section changes direction. The location of the seismic section is shown on Fig. 1; abbreviations as in Fig. 49.

ments and minor turbidite channels, to mainly silty turbidite deposits that represent distal levee and fan fringe environments and the transition to the open slope. The source of the sand was probably a marginal marine shelf environment, judging by the abundance of the marginal marine acritarch Paralecaniella indentata.

Age. In the type well, the Freja Member is Chattian to Aquitanian in age, based on the age of mudstones within and bounding the member. In the Frida-1 well, the Freja Member is entirely Chattian in age.

Correlation. The Freja Member is broadly contemporaneous with the Vejle Fjord Formation onshore Denmark, with the Vade Formation (Hardt et al. 1989) in the Norwegian Central Graben and with the Skade Formation (Hardt et al. 1989) in the Viking Graben. Thick, coarsening-upward sandstone bodies are present above the Dufa Mem- 
Frida-1

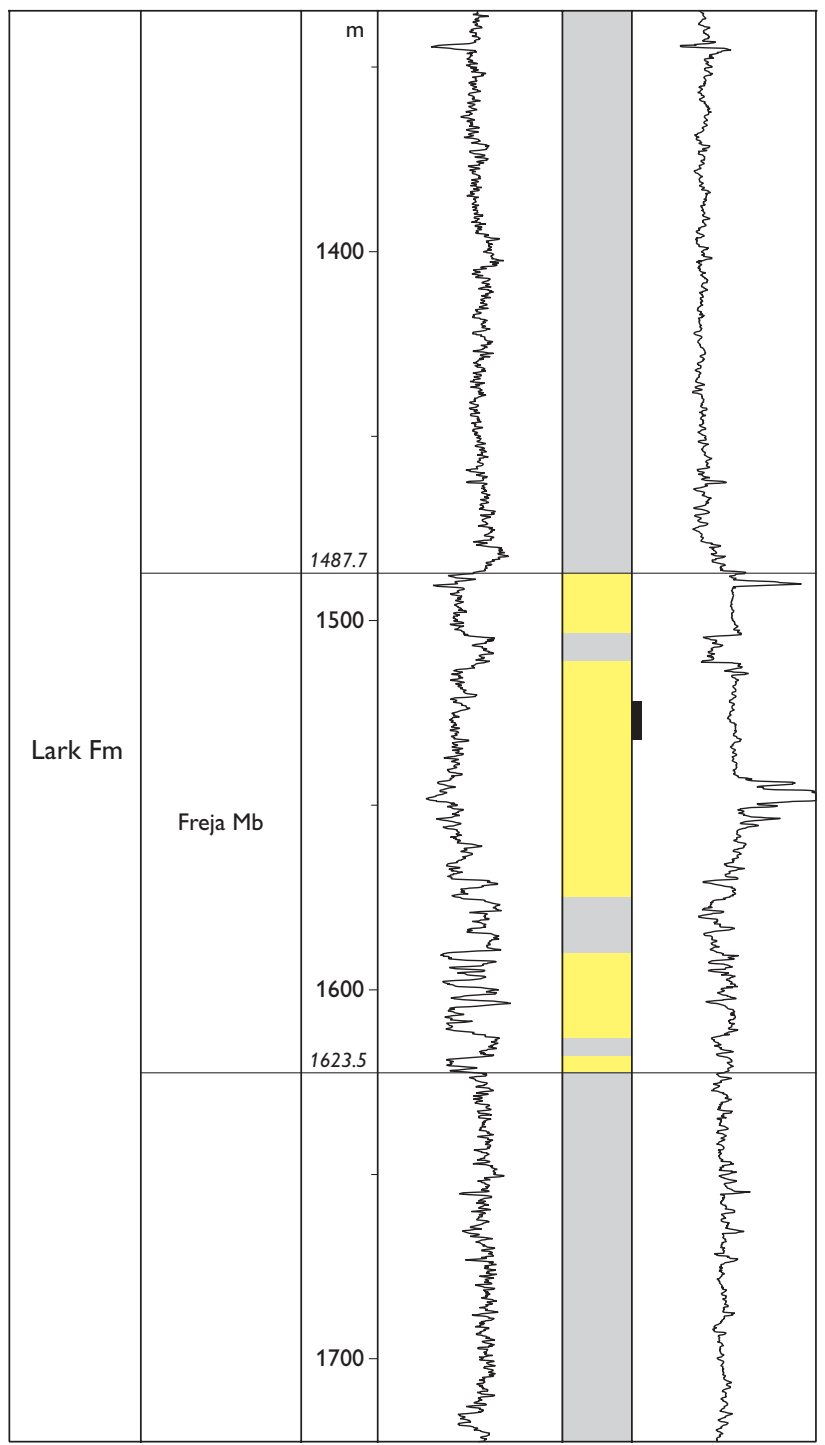

Fig. 62. Frida-1, reference well for the Freja Member. Black bar shows cored section.

ber in the Inez-1 well (shown as unnamed sandstones in Fig. 2); these sandstones may be contemporaneous or even contiguous with those of the Freja Member. However, confident correlation on the basis of log and seismic data is not possible at present.

\section{Acknowledgements}

Aage Bach Sørensen (GEUS) is thanked for help with seismic interpretations. Yvonne Desezar, Johnny E. Hansen and Birthe Amdrup are thanked for preparation of microfossil and palynology samples. The referees Robert W.O'B. Knox (British Geological Survey) and Paul van Veen (ConocoPhilips Norway) are thanked for their constructive criticism of the manuscript; the editorial contributions of Adam A. Garde, Jon R. Ineson and Martin Sønderholm are gratefully acknowledged. This work was made possible through grants from the Danish Energy Authority, under the Energy Research Project Framework 2000 .

\section{References}

Ahmadi, Z.M., Sawyers, M., Kenyon-Roberts, S., Stanworth, C.W., Kugler, K.A., Kristensen, J. \& Fugelli, E.M.G. 2003: Paleocene. In: Evans, D. et al. (eds): The millenium atlas: petroleum geology of the central and northern North Sea, 235-259. London: Geological Society.

Armentrout, J.M., Malecek, S.J., Fearn, L.B., Sheppard, C.E., Nayler, P.H., Miles, A.W., Desmarais, R.J \& Dunay, R.E. 1993: Log-motif analysis of Paleogene depositional systems tracts, central and northern North Sea: defined by sequence stratigraphic analysis. In: Parker, J.R. (ed.): Petroleum geology of Northwest Europe: proceedings of the 4th conference, 45-57. London: Geological Society.
Aubry, M.-P. et al. 2002: Proposal: Global Standard Stratotype-section and Point (GSSP) at the Dababiya section (Egypt) for the base of the Eocene Series, 58 pp. Unpublished report, International Subcommision on Paleogene Stratigraphy.

Aubry, M.-P. et al. 2003: Chronostratigraphic terminology at the Paleocene/Eocene boundary. Geological Society of America, Special Paper 369, 551-566.

Berggren, W.A. \& Aubert, J. 1975: Paleocene benthonic foraminiferal biostratigraphy, paleobiogeography and paleoecology of AtlanticTethyan regions; Midway-type fauna. Palaeogeography, Palaeoclimatology, Palaeoecology 18, 73-192. 
Berggren, W.A. \& Aubry, M.-P. 1996: A Late Paleocene - Early Eocene NW European and North Sea magnetobiochronological correlation network. In: Knox, R.W.O’B., Corfield, R.M. \& Dunay, R.E. (eds): Correlation of the Early Paleogene in Northwest Europe. Geological Society Special Publication (London) 101, 309-352.

Berggren, W.A. \& Miller, K.G. 1988: Paleogene tropical planktonic foraminiferal biostratigraphy and magnetobiochronology. Micropaleontology 34, 362-380.

Berggren, W.A., Kent, D.V. \& van Couvering, J.A. 1985a: Neogene geochronology and chronostratigraphy. In: Snelling, N.J. (ed.): The chronology of the geological record. Geological Society Memoir (London) 10, 211-260.

Berggren, W.A., Kent, D.V. \& Flynn, J.J. 1985b: Paleogene geochronology and chronostratigraphy. In: Snelling, N.J. (ed.): The chronology of the geological record. Geological Society Memoir (London) 10, 141-195.

Berggren, W.A., Kent, D.V., Swischer III, C.C. \& Aubry, M.-P. 1995: A revised Cenozoic geochronology and chronostratigraphy. In: Berggren, W.A. et al. (eds): Geochronology, time scale and global stratigraphic correlation. Society for Sedimentary Geology (SEPM) Special Publication 54, 129-212.

Bøggild, O.B. 1918: Den vulkanske Aske i Moleret samt en Oversigt over Danmarks ældre Tertiærbjergarter. Danmarks Geologiske Undersøgelse II. Række 33, 159 pp.

Bonde, N. 1966: The fishes of the Mo-clay Formation (Lower Eocene). Bulletin of the Geological Society of Denmark 16, 198-202.

Bonde, N. 1974: Palaeoenvironment as indicated by the 'Mo-clay formation' (lowermost Eocene of Denmark). Tertiary Times 2, 29-36.

Bonde, N. 1979: Palaeoenvironment in the 'North Sea' as indicated by the fish bearing Mo-clay deposit (Paleocene/Eocene), Denmark. Mededelingen Werkgroup Tertiair en Kwartair Geologie 16, 3-16.

Bonde, N. 1987: Moler - its origin and its fossils, especially fishes, 53 pp. Nykøbing Mors: Skamol.

Bonde, N. 2003: Moleret - en guldgrube af fortidens livsformer. Geografisk Orientering 3, 90-96.

Bottjer, D.J. \& Droser, M.L. 1992: Paleoenvironmental patterns of biogenic sedimentary structures. In: Maples, C.G. \& West, R.R. (eds): Trace fossils. Paleontological Society, Short courses in Paleontology 5, 130-144.

Brinkhuis, H. \& Biffi, U. 1993: Dinoflagellate cyst stratigraphy of the Eocene/Oligocene transition in central Italy. Marine Micropaleontology 22, 131-183.

Brinkhuis, H. \& Visscher, H. 1995: The upper boundary of the Eocene Series: a reappraisal based on dinoflagellate cyst biostratigraphy and sequence stratigraphy. In: Berggren, W.A. et al. (eds): Geochronology, time scale and global stratigraphic correlation. Society for Sedimentary Geology (SEPM) Special Publication 54, 295-304.

Brinkhuis, H., Powell, A. J. \& Zevenboom, D. 1992: High-resolution dinoflagellate cyst stratigraphy of the Oligocene/Miocene transition interval in northwest and central Italy. In: Head, M.J. \& Wrenn, J.H. (eds): Neogene and Quaternary dinoflagellate cysts and acritarchs, 219-258. Dallas: American Association of Stratigraphic Palynologists Foundation.

Christensen, L. \& Ulleberg, K. 1973: Sedimentology and micropalae- ontology of the Middle Oligocene sequence at Sofienlund, Denmark. Bulletin of the Geological Society of Denmark 22, 283-305.

Clemmensen, A. \& Thomsen, E. 2005: Palaeoenvironmental changes across the Danian-Selandian boundary in the North Sea Basin. Palaeogeography, Palaeoclimatology, Palaeoecology 219, 351-394.

Costa, L.I. \& Manum, S. 1988: The description of the interregional zonation of the Paleogene (D1-D15) and the Miocene (D16-D20). Geologisches Jahrbuch, Reihe A 100, 321-330.

Crouch, E., Heilmann-Clausen, C., Brinkhuis, H., Morgans, H.E.G., Rogers, K.M., Egger, H. \& Schmitz, B. 2001: Global dinoflagellate event associated with the Paleocene-Eocene thermal maximum. Geology 29, 315-318.

Danielsen, M. \& Thomsen, E. 1997: Paleocene/Eocene diatomite in wells in the eastern North Sea. In: Thomsen, E. \& Pedersen, S.A.S. (eds): Geology and palaeontology of the Mo-clay. Aarhus Geoscience 6, 19-24.

Danielsen, M., Michelsen, O. \& Clausen, O.R. 1997: Oligocene sequence stratigraphy and basin development in the Danish sector of the North Sea based on log interpretations. Marine and Petroleum Geology 14, 931-950.

de Verteuil, L. \& Norris, G. 1996: Part I, Dinoflagellate cyst zonation and allostratigraphy of the Chesapeake Group. Micropaleontology 42, supplement, 1-82.

Deegan, C.E. \& Scull, B.J. (compilers) 1977: A standard lithostratigraphic nomenclature for the central and northern North Sea. Institute of Geological Sciences Report 77/25, 36 pp. London: Her Majesty's Stationery Office.

Dybkjær, K. 2004: Dinocyst stratigraphy and palynofacies studies used for refining a sequence stratigraphic model - uppermost Oligocene to lower Miocene, Jylland, Denmark. Review of Palaeobotany and Palynology 131, 201-249.

Dybkjær, K. \& Rasmussen, E.S. 2000: Palynological dating of the Oligocene-Miocene successions in the Lille Bælt area, Denmark. Bulletin of the Geological Society of Denmark 47, 87-103.

Fyfe, J.A., Gregersen, U., Jordt, H., Rundberg, Y., Eidvin, T., Evans, D., Steward, D., Hovland, M. \& Andresen, P. 2003: Oligocene to Holocene. In: Evans, D. et al. (eds): The millenium atlas: petroleum geology of the central and northern North Sea, 279-287. London: Geological Society.

Gradstein, F.M. \& Bäckström, S. 1996: Cainozoic biostratigraphy and palaeobathymetry, northern North Sea and Haltenbanken. Norsk Geologisk Tidsskrift 76, 3-32.

Gradstein, F.M. \& Ogg, J.G. (compilers) 2002: International Union of Geological Sciences, International Commission on Stratigraphy (ICS), Consolidated Annual Report for 2002, 157 pp. Available on: $<$ http://www.stratigraphy.org/report02.pdfs.

Gradstein, F.M., Kaminski, M.A., Berggren, W.A., Kristiansen, I.L. \& D'Ioro, M.A. 1994: Cenozoic biostratigraphy of the North Sea and Labrador shelf. Micropaleontology 40, supplement, 1-152.

Haaland, H.J., Furnes, H. \& Martinsen, O.J. 2000: Paleogene tuffaceous intervals, Grane Field (Block 25/11), Norwegian North Sea: their depositional, petrographical, geochemical character and regional implications. Marine and Petroleum Geology 17, 101-118. 
Håkansson, E. \& Sjørring, S. 1982: En molerprofil i kystklinten ved Salger Høj, Mors. Dansk Geologisk Forening, Årskkrift 1981, 131134.

Hamberg, L., Dam, G., Wilhelmson, C. \& Ottesen, T.G. 2005: Paleocene deep-marine sandstone plays in the Siri Canyon, offshore Denmark - southern Norway. In: Doré, A.G. \& Vining, B.A. (eds): Petroleum geology: North-West Europe and global perspectives. Proceedings of the 6th petroleum geology conference, 1185-1198. London: Geological Society.

Hansen, J.M. 1979: Age of the Mo-Clay Formation. Bulletin of the Geological Society of Denmark 27, 89-91.

Haq, B.U., Hardenbol, J. \& Vail, P.R. 1987: Chronology of fluctuating sea-levels since the Triassic. Science 235, 1156-1167.

Hardenbol, J., Thierry, J., Farley, M.B., Jacquin, T., de Graciansky, P.C. \& Vail, P. 1998: Mesozoic and Cenozoic sequence chronostratigraphic framework of European basins. In: de Graciansky, P.-C. et al. (eds): Mesozoic and Cenozoic sequence stratigraphy of European basins. Society for Sedimentary Geology (SEPM) Special Publication 60, 3-13.

Hardt, T., Holtar, E., Isaksen, D., Kyllingstad, G., Lervik, K.S., Lycke, A.S. \& Tonstad, K. 1989: Revised Tertiary lithostratigraphic nomenclature for the Norwegian North Sea. In: Isaksen, D. \& Tonstad, K. (eds): A revised Cretaceous and Tertiary lithostratigraphic nomenclature for the Norwegian North Sea. Norwegian Petroleum Directorate (NPD) Bulletin 5, 35-55.

Heilmann-Clausen, C. 1982: The Paleocene-Eocene boundary in Denmark. Newsletters on Stratigraphy 11, 55-63.

Heilmann-Clausen, C. 1985: Dinoflagellate stratigraphy of the uppermost Danian to Ypresian in the Viborg-1 borehole, central Jylland, Denmark. Danmarks Geologiske Undersøgelse Serie A 7, 69 pp.

Heilmann-Clausen, C. 1995: Palæogene aflejringer over Danskekalken. In: Nielsen, O.B. (ed.): Danmarks geologi fra Kridt til i dag. Aarhus Geokompendier 1, 69-114.

Heilmann-Clausen, C. \& Schmitz, B. 2000: The late Paleocene thermal maximum $\delta^{13} \mathrm{C}$ excursion in Denmark. In: Schmitz, B., Sundquist, B. \& Andreasson, F.P. (eds): Early Paleogene warm climates and biosphere dynamics, short papers and extended abstracts from an international meeting in Göteborg, Sweden, June 9-13, 1999. GFF 122, 70 only. Stockholm: Geological Society of Sweden.

Heilmann-Clausen, C., Nielsen, O.B. \& Gersner, F. 1985: Lithostratigraphy and depositional environments in the upper Paleocene and Eocene of Denmark. Bulletin of the Geological Society of Denmark 33, 287-323.

Huuse, M. \& Clausen, O.R. 2001: Morphology and origin of major Cenozoic sequence boundaries in the eastern North Sea basin: top Eocene, near-top Oligocene and the mid-Miocene unconformity. Basin Research 13, 17-41.

Isaksen, D. \& Tonstad, K. 1989 (eds): A revised Cretaceous and Tertiary lithostratigraphic nomenclature for the Norwegian North Sea. Norwegian Petroleum Directorate (NPD) Bulletin 5, 59 pp.

Jones, E., Jones, R., Ebdon, C., Ewen, D., Milner, P., Plunkett, J., Hudson, G. \& Slater, P. 2003: Eocene. In: Evans, D. et al. (eds): The millenium atlas: petroleum geology of the central and northern North Sea, 261-277. London: Geological Society.

Jones, R.W. 1999: Forties Field (North Sea) revisited: a demonstration of the value of historical micropalaeontological data. In: Jones, R.W. \& Simmons, M.D. (eds): Biostratigraphy in production and development geology. Geological Society Special Publication (London) 152, 185-200.

Joy, A.M. 1996: Controls on Eocene sedimentation in the central North Sea Basin: results of a basinwide correlation study. In: Knox, R.W.O’B., Corfield, R.M. \& Dunay, R.E. (eds): Correlation of the Early Paleogene in Northwest Europe. Geological Society Special Publication (London) 101, 79-90.

King, C. 1983: Cainozoic micropaleontological biostratigraphy of the North Sea. Institute of Geological Sciences Report 82/7, 40 pp.

King, C. 1989: Cenozoic of the North Sea. In: Jenkins, D.G. \& Murray, J.W. (eds): Stratigraphic atlas of fossil foraminifera, 2nd edition, 418-489. Chichester: Ellis Horwood Ltd.

Knox, R.W.O'B. 1996: Correlation of the Early Paleogene in Northwest Europe: an overview. In: Knox, R.W.O’B., Corfield, R.M. \& Dunay, R.E. (eds): Correlation of the Early Paleogene in Northwest Europe. Geological Society Special Publication (London) 101, 111.

Knox, R.W.O’B. 1997: The late Paleocene to early Eocene ash layers of the Danish Mo-Clay (Fur Formation): stratigraphic and tectonic significance. In: Thomsen, E. \& Pedersen, S.A.S. (eds): Geology and palaeontology of the Mo-clay. Aarhus Geoscience 6, 7-11.

Knox, R.W.O'B. \& Holloway, S. 1992: 1. Paleogene of the central and northern North Sea. In: Knox, R.W.O’B. \& Cordey, W.G. (eds): Lithostratigraphic nomenclature of the UK North Sea, 133 pp. Nottingham: British Geological Survey.

Knox, R.W.O’B., Morton, A.C. \& Harland, R. 1981: Stratigraphical relationships of Paleocene sands in the UK sector of the central North Sea. In: Illing, L.V. \& Hobson, G.D. (eds): Petroleum geology of the continental shelf of North-West Europe: proceedings of the 2nd conference, 267-281. London: Heyden \& Son Ltd.

Kristoffersen, A.V. 2001: An Early Paleogene trogon (Aves: Trogoniformes) from the Fur Formation, Denmark. Journal of Vertebrate Paleontology 22, 661-666.

Kristoffersen, F.N. \& Bang, I. 1982: Cenozoic excl. Danian Limestone. In: Michelsen, O. (ed.): Geology of the Danish Central Graben. Danmarks Geologiske Undersøgelse Serie B 8, 62-71.

Köthe, A. 1990: Paleogene dinoflagellates from Northwest Germany. Geologische Jahrbuch, Reihe A 118, 111 pp.

Köthe, A. 2003: Dinozysten-Zonierung im Tertiär Norddeutschlands. Revue Paleobiologie 22, 895-923.

Larsen, G. \& Dinesen, A. 1959: Vejle Fjord Formationen ved Brejning. Sedimenterne og foraminiferfaunaen (Oligocæn-Miocæn). Danmarks Geologiske Undersøgelse II. Række 82, 114 pp.

Martini, E. 1971: Standard Tertiary and Quaternary calcareous nannoplankton zonation. In: Farinacci, A. (ed.): Proceedings of the second planktonic conference Roma 1970. Edizioni Tecnoscienza Roma 2, 739-785.

Michelsen, O. 1993: Stratigraphic correlation of the Danish onshore and offshore Tertiary successions based on sequence stratigraphy. Bulletin of the Geological Society of Denmark 41, 145-161.

Michelsen, O., Danielsen, M., Heilmann-Clausen, C., Jordt, H., Laursen, G. \& Thomsen, E. 1992: Cenozoic sequence stratigraphy 
in the eastern North Sea. Final report of the CENOS-project, 51 pp. Geological Institute, University of Aarhus, Denmark.

Michelsen, O., Danielsen, M., Heilmann-Clausen, C., Jordt, H., Laursen, G. \& Thomsen, E. 1995: Occurrence of major sequence stratigraphic boundaries in relation to basin development in Cenozoic deposits of the southeastern North Sea. In: Steel, R.J. et al. (eds): Sequence stratigraphy on the Northwest European margin. Norwegian Petroleum Society (NPF) Special Publication 5, 415427.

Michelsen, O., Thomsen, E., Danielsen, M., Heilmann-Clausen, C., Jordt, H. \& Laursen, G. 1998: Cenozoic sequence stratigraphy in the eastern North Sea. In: de Graciansky, P.-C. et al. (eds): Mesozoic and Cenozoic sequence stratigraphy of European basins. Society for Sedimentary Geology (SEPM) Special Publication 60, 91-118.

Mitlehner, A.G. 1996: Palaeoenvironments in the North Sea basin around the Paleocene-Eocene boundary: evidence from diatoms and other siliceous microfossils. In: Knox, R.W.O’B., Corfield, R.M. \& Dunay, R.E. (eds): Correlation of the Early Paleogene in Northwest Europe. Geological Society Special Publication (London) 101, 255273.

Mudge, D.C. \& Bujak, J.P. 1994: Eocene stratigraphy of the North Sea Basin. Marine and Petroleum Geology 11, 166-181.

Mudge, D.C. \& Bujak, J.P. 1996a: Paleocene biostratigraphy and sequence stratigraphy of the UK central North Sea. Marine and Petroleum Geology 13, 295-312.

Mudge, D.C. \& Bujak, J.P. 1996b: An integrated stratigraphy for the Paleocene and Eocene of the North Sea. In: Knox, R.W.O'B., Corfield, R.M. \& Dunay, R.E. (eds): Correlation of the Early Paleogene in Northwest Europe. Geological Society Special Publication (London) 101, 91-113.

Mudge, D.C. \& Bujak, J.P. 2001: Biostratigraphic evidence for evolving palaeoenvironments in the Lower Paleogene of the Faeroe-Shetland Basin. Marine and Petroleum Geology 18, 577-590.

Mudge, D.C. \& Copestake, P. 1992a: Revised Lower Palaeogene lithostratigraphy for the Outer Moray Firth, North Sea. Marine and Petroleum Geology 9, 53-69.

Mudge, D.C. \& Copestake, P. 1992b: Lower Palaeogene stratigraphy of the northern North Sea. Marine and Petroleum Geology 9, 287301.

Munsterman, D.K \& Brinkhuis, H. 2004: A southern North Sea Miocene dinoflagellate cyst zonation. Netherlands Journal of Geosciences / Geologie en Mijnbouw 83, 267-285.

Neal, J.E., Stein, J.A. \& Gamber, J.H. 1994: Graphic correlation and sequence stratigraphy in the Palaeogene of NW Europe. Journal of Micropalaeontology 13, 55-80.

Nielsen, O.B., Baumann, J., Deyu, Z., Heilmann-Clausen, C. \& Larsen, G. 1986: The Tertiary section of borehole D.G.I. 83101, Østerrenden, Storebælt, Denmark. In: Møller, T.J. (ed.): Twenty-five years of geology in Aarhus. Geoskrifter 25, 235-253.

O'Connor, S.J. \& Walker, D. 1993: Paleocene reservoirs of the Everest trend. In: Parker, R.J. (ed.): Petroleum geology of Northwest Europe: proceedings of the 4th conference, 145-160. London: Geological Society.

Pedersen, G.K. 1981: Anoxic events during sedimentation of a Paleogene diatomite in Denmark. Sedimentology 28, 487-504.
Pedersen, G.K. \& Surlyk, F. 1983: The Fur Formation, a Late Paleocene ash-bearing diatomite from northern Denmark. Bulletin of the Geological Society of Denmark 32, 43-65.

Perch-Nielsen, K. 1976: New silicoflagellates and silicoflagelate zonation in north European Paleocene and Eocene diatomites. Bulletin of the Geological Society of Denmark 25, 27-40.

Piasecki, S. 2005: Dinoflagellate cysts of the Middle-Upper Miocene Gram Formation, Denmark. Palaeontos 7, 29-45.

Powell, A.J. 1986: Latest Palaeogene and earliest Neogene dinoflagellate cysts from the Lemme section, northwest Italy. American Association of Stratigraphic Palynologists Foundation, Contribution Series $\mathbf{1 7}, 83-104$.

Premoli Silva, I. 2005: Annual report 2004 of the Rupelian/Chattian Boundary Stratotype Working Group. Available on International Subcommision on Palaeogene Stratigraphy: <http://wzar.unizar.es/ isps/chattian2004.htm>

Premoli Silva, I. \& Jenkins, D.G. 1993: Decision on the Eocene-Oligocene boundary stratotype. Episodes 16, 379-382.

Rasmussen, E.S. 2004a: Stratigraphy and depositional evolution of the uppermost Oligocene-Miocene succession in western Denmark. Bulletin of the Geological Society of Denmark 51, 89-109.

Rasmussen, E.S. 2004b: The interplay between true eustatic sea-level changes, tectonics, and climate changes: What is the dominating factor in sequence formation of the Upper Oligocene - Miocene succession in the eastern North Sea Basin, Denmark? Global and Planetary Change 41, 15-30.

Rasmussen, L.B. 1961: De miocæne formationer i Danmark. Danmarks Geologiske Undersøgelse IV. Række 5, 45 pp.

Ravn, J.P.J. 1906: Om det saakaldte plastiske Lers Alder. Meddelelser fra Dansk Geologisk Forening 2, 23-28.

Rhys, G.H. 1974: A proposed standard lithostratigraphic nomenclature for the southern North Sea and an outline structural nomenclature for the whole of the (UK) North Sea. British Geological Survey Report 74/8, 14 pp.

Rønnevik, H.C., van den Bosch, W. \& Bandlien, E.H. 1975: A proposed nomenclature for the main structural features in the Norwegian North Sea. In: Finstad, K.G. \& Selley, R.C. (coordinators): Jurassic Northern North Sea Symposium, Stavanger, 28-30 September 1975. Norwegian Petroleum Society (NPF) Proceedings JNNS/18, 1-16.

Salvador, A. (ed.) 1994: International stratigraphic guide: a guide to stratigraphic classification, terminology and procedure, $214 \mathrm{pp}$. Boulder: The International Union of Geological Sciences, IUGS Secretariat, Trondheim and the Geological Society of America, Inc.

Schiøler, P. 2005: Dinoflagellate cysts and acritarchs from the Oligocene - Lower Miocene interval of the Alma-1X well, Danish North Sea. Journal of Micropalaeontology 24, 1-37.

Schiøler, P., Andsbjerg, J., Clausen, O.R., Dam, G., Dybkjær, K., Hamberg, L., Heilmann-Clausen, C., Kristensen, L.E., Prince, I. \& Rasmussen, J.A. 2005: A revised lithostratigraphy for the Palaeogene lower Neogene of the Danish North Sea. Geological Survey of Denmark and Greenland Bulletin 7, 21-24.

Schmitz, B., Heilmann-Clausen, C., King, C., Steurbaut, E., Andreasson, F.P., Corfield, R.M. \& Cartlidge, J.E. 1996: Stable isotope and biotic evolution in the North Sea during the Early Eocene: the Al- 
bæk Hoved section, Denmark. In: Knox, R.W.O'B., Corfield, R.M. \& Dunay, R.E. (eds): Correlation of the Early Paleogene in Northwest Europe. Geological Society Special Publication (London) 101, 276-306.

Sorgenfrei, T. 1958: Molluscan assemblages from the marine middle Miocene of South Jutland and their environments. Danmarks Geologiske Undersøgelse II. Række 79, 503 pp.

Steininger, F.F. et al.1997: The global stratotype section and point (GSSP) for the base of the Neogene. Episodes 20, 23-28.

Stow, D.A.V. \& Johansson, M. 2000: Deep-water massive sands: nature, origin and hydrocarbon implications. Marine and Petroleum Geology 17, 145-174.

Thomsen, E. 1994: Calcareous nannofossil stratigraphy across the Danian-Selandian boundary in Denmark. GFF 116, 65-67. Stockholm: Geological Society of Sweden.

Thomsen, E. \& Danielsen, M. 1995: Transitional Paleocene/Eocene ash-bearing diatomite in the eastern North Sea. Tertiary Research 15, 111-120.

van Simaeys, S., de Man, E., Vandenberghe, N., Brinkhuis, H. \& Steurbaut, E. 2004: Stratigraphic and palaeoenvironmental analysis of the Rupelian-Chattian transition in the type region: evidence from dinoflagellate cysts, foraminifera and calcareous nannofossils. Palaeogeography, Palaeoclimatology, Palaeoecology 208, 31-58.
Williams, G.L., Brinkhuis, H., Pearce, M.A., Fensome, R.A. \& Weegink, J.W. 2004: Southern Ocean and global dinoflagellate cyst events compared: index events for the Late Cretaceous - Neogene. In: Exon, N.F., Kennett, J.P. \& Malone, M.J. (eds): Proceedings of the Ocean Drilling Program, Scientific Results 189, 1-98. Available on: <http://www-odp.tamu.edu/publications/189_sr/volume/chapters/ 107.pdfs.

Willumsen, P.S. 2004: Palynology of the Lower Eocene deposits of northwest Jutland, Denmark. Bulletin of the Geological Society of Denmark 52, 141-157.

Zevenboom, D. 1995: Dinoflagellate cysts from the Mediterranean Late Oligocene and Miocene, 221 pp. Unpublished Ph.D. thesis, University of Utrecht, The Netherlands.

Zevenboom, D. 1996: Late Oligocene - early Miocene dinoflagellate cysts from the Lemme-Carrosio section (NW Italy); biostratigraphy and palaeoenvironmental interpretation. Giornale di Geologia, Ser. 3a 58, 81-93.

Ziegler, P.A. 1981: Evolution of sedimentary basins in North-West Europe. In: Illing, L.V. \& Hobson, G.D. (eds): Petroleum geology of the continental shelf of North-West Europe: proceedings of the 2nd conference, 3-39. London: Heyden \& Son Ltd. 


